HERBERT GHERSEL

RELAÇÃO ENTRE FORÇA E DEFLEXÃO NA ATIVAÇÃO E DESATIVAÇÃO DE FIOS ORTODÔNTICOS DE NÍQUEL-TITÂNIO 


\section{Herbert Ghersel}

Relação entre força e deflexão na ativação e desativação de fios ortodônticos de níquel-titânio

Tese apresentada à Faculdade de Odontologia da Universidade de São Paulo, para obter o título de Doutor pelo Programa de Pós-Graduação em Odontologia.

Área de Concentração: Materiais Dentários

Orientador: Prof. Dr. Antonio Muench 


\section{FOLHA DE APROVAÇÃO}

Ghersel, H. Relação entre força e deflexão na ativação e desativação de fios ortodônticos de níquel-titânio [Tese de Doutorado]. São Paulo: Faculdade de Odontologia da USP; 2005

São Paulo,

\section{Banca Examinadora}

1) $\operatorname{Prof}(a) \cdot \operatorname{Dr}(a)$.

Titulação:

Julgamento:

Assinatura:

2) $\operatorname{Prof}(a)$. $\operatorname{Dr}(a)$.

Titulação:

Julgamento:

Assinatura:

3) $\operatorname{Prof}(a) . \operatorname{Dr}(a)$.

Titulação:

Julgamento:

Assinatura:

4) $\operatorname{Prof}(a) \cdot \operatorname{Dr}(a)$.

Titulação:

Julgamento:

Assinatura:

5) $\operatorname{Prof}(a)$. $\operatorname{Dr}(a)$.

Titulação:

Julgamento:

Assinatura: 
Eloisa, que soube ser âncora durante a tempestade, me mantendo firme em um porto seguro, que soube ser vela durante a viagem, transmitindo a força necessária à jornada, que soube ser lastro quando precisei de estabilidade e soube ser asa quando precisei voar.

Lorena e Amanda: o simples fato de existirem já me dá o estímulo necessário para lutar e vencer, mas seu carinho e sua infinita curiosidade, com incontáveis "comos" e "porquês" são faróis em minha jornada. 
Creio na morte, única amante absolutamente fiel.

Creio na estupidez humana, única força com que se pode contar sempre.

E creio no humor, única forma de encarar a primeira e suportar a segunda.

(Marco A. dos Santos) 
Ghersel H. Relação entre força e deflexão na ativação e desativação de fios ortodônticos de níqueltitânio [Tese de Doutorado]. São Paulo: Faculdade de Odontologia da USP; 2005.

\section{RESUMO}

O objetivo da presente pesquisa foi avaliar o comportamento da força em função da deflexão na ativação e desativação de fios ortodônticos de níquel-titânio, de secção circular (.016"). Ensaiaram-se três marcas de fio (Forestadent, GAC e Morelli). As temperaturas de ensaio foram três $\left(32,37\right.$ e $\left.42^{\circ} \mathrm{C}\right)$. As ativações máximas foram até 1, 2, 3 e 4mm. O espécime de ensaio consistiu de uma placa de resina acrílica, sobre a qual eram fixados cilindros metálicos por meio de parafusos, simulando dentes, com distribuição semelhante aos dentes naturais. Sobre os cilindros foram cimentados os bráquetes (distância de $8 \mathrm{~mm}$ entre eles). Sobre os bráquetes era fixado, conforme clinicamente, o arco do fio em ensaio. O "dente" correspondente ao incisivo central era liberado (desparafusado) para poder se deslocar livremente no sentido vestíbulo-lingual durante os ensaios e o fio poder sofrer a deflexão. $\mathrm{O}$ conjunto era levado à máquina de ensaio (Instron), com câmara de temperatura controlada. Durante o ensaio a velocidade de deslocamento para a deflexão foi de $0,5 \mathrm{~mm} / \mathrm{min}$. Durante a ativação e desativação as forças foram registradas de 0,10 em $0,10 \mathrm{~mm}$ de deflexão. Por meio de software esses valores eram impressos numericamente e em gráficos da força em função da ativação/desativação. Com 4 ativações máximas, 3 marcas de fios e 3 temperaturas obtiveram-se 36 condições experimentais e com 5 repetições $(n=5)$ foram feitos 180 ensaios. Os gráficos obtidos mostraram uma não linearidade entre força e deflexão e com ativação de 1 e 
$2 \mathrm{~mm}$ não foi detectado platô de superelasticidade, mas que foi observado na desativação, das ativações máximas de 3 e $4 \mathrm{~mm}$. Dos gráficos e tabelas foram extraídos valores específicos para serem analisados e comparados: 1) força máxima de ativação; 2/3) diminuição da força na desativação de 0,20mm e 0,70mm (esta só na ativação de 3 e $4 \mathrm{~mm}$ ); 4/5) extensão e forças no platô (apenas nas ativações máximas de 3 e 4mm); 6/7/8) desativação até alcançar $50 \mathrm{~g}$ de força, a partir de 0,80 e 1,80mm (ativações de 1 e $2 \mathrm{~mm}$ ), ou no final dos platôs (ativações de 3 e $4 \mathrm{~mm}$ ), a força ao iniciar-se a desativação, afastamento da origem ao registrar $50 \mathrm{~g}$ de força; 9) deformação permanente ao atingir a força zero. As principais conclusões foram: a força de ativação máxima aumentou com o aumento desta e da temperatura, o material Morelli apresentou a menor e o GAC a maior; a diminuição da força máxima foi tanto maior quanto maior a ativação; apenas as ativações até 3 e 4mm apresentaram platôs de superelasticidade e que foram bem mais extensos na ativação de $4 \mathrm{~mm}$, que por sua vez apresentaram menor força; em todos os ensaios for observada deformação permanente.

Palavras Chave: Fios ortodônticos; Fios de níquel-titânio; Superelasticidade 
Ghersel H. Relation of forces and deflections during loading and unloading orthodontic nickel-titanium wires [Tese de Doutorado]. São Paulo: Faculdade de Odontologia da USP; 2005.

\section{ABSTRACT}

The purpose of this study was to evaluate the behaviour of force as function of loading and unloading orthodontic nickel-titanium wires. Three defferent brands (Forestadent, GAC and Morelli) were tested. Testing temperature were 32, 37 and

$42^{\circ} \mathrm{C}$. Loading were up to $1,2,3$ and $4 \mathrm{~mm}$ deflection. Specimens consisted of a acrylic base where were fixed metallic cylinders simulating teeth. Over the teeth were fixed brackets to maintain arch wire in position. Tooth corresponding to central incisor was loosened and at the correspondig bráquete was applied the force in an Instron equipment, with temperature control. Head speed was $0.5 \mathrm{~mm} / \mathrm{min}$. During loading and unloading forces were read every $0.10 \mathrm{~mm}$ deflection and registered. The pair values of forces and deflections were also plotted as graphs. With $4 \mathrm{~mm}$ maximum loading, 3 brands and 3 temperatures were obtained 36 experimental conditions and with 5 repetitions $(n=5)$ were performed 180 tests. Graphs showed that there is no linearity between forces and deflection and with loading up to 1 and $2 \mathrm{~mm}$ was not obtained the formation of superelasticity plateaus. But they were observed with 3 and $4 \mathrm{~mm}$ deflections. From the graphs and registered numerical values for each specimen were selected special values to be analysed: 1) maximum loading force; $2 / 3$ ) force decrease during unloading 0.20 and $0.70 \mathrm{~mm}$ (the last only at 3 and $4 \mathrm{~mm}$ activation); 4/5) extensions and forces at plateaus (only for 3 and $4 \mathrm{~mm}$ activations); 6/7/8) extension until $50 \mathrm{~g}$ force, since 0.80 and $1.80 \mathrm{~mm}$ (respectively 
activation up to 1 and $2 \mathrm{~mm}$ ), or ends of plateau ( 3 and $4 \mathrm{~mm}$ activation). In these conditions, the force at beginning unloading. Distance of origin at register $50 \mathrm{~g}$ force; 9) permanent deformation at zero force. The main conclusions were: maximum loading forces increase with deflection and temperature increases, and brand Morelli presented the smallest force and GAC the greatest; the decrease of forces with unloading was as larger as activation force; only the activation until 3 and $4 \mathrm{~mm}$ presented superelasticity plateaus, and was longer with $4 \mathrm{~mm}$ activation, but it presented lower force at plateaus; in all tests was noted permanent deformation.

Keywords: Orthodontic wires; Nickel-titanium wires; Superelasticity 


\section{LISTA DE FIGURAS}

Figura 2.1 - Rigidez flexural relativa dos fios de aço inoxidável.

Figura 2.2 - Forças ótimas para o movimento dentário ortodôntico.

Figura 4.1 - Placa de resina acrílica perfurada 88

Figura 4.2 - Cilindro metálico com bráquete colado 88

Figura 4.3 - Placa de resina acrílica com os cilindros metálicos parafusados e bráquetes colados

Figura 4.4 - Modelo de simulação clínica 90

Figura 4.5- Ponta da máquina Instron executando deslocamento sobre o cilindro metálico desparafusado

Figura 4.6 - Curvas de ativação e desativação (força = função do afastamento da origem). Afastamento até (mm): I, 1mm; II, 2mm; III, 3mm; IV, 4mm. .94

Figura 5.1 - Curvas de ativação e desativação (força = função do afastamento da origem) para os fios

Forestadent, GAC e Morelli, nas temperaturas de $32^{\circ} \mathrm{C}, 37^{\circ} \mathrm{C}$ e $42^{\circ} \mathrm{C}$, com ativação de $1,0 \mathrm{~mm}$

Figura 5.2 - Curvas de ativação e desativação (força = função do afastamento da origem) para os fios

Forestadent, GAC e Morelli, nas temperaturas de $32^{\circ} \mathrm{C}, 37^{\circ} \mathrm{C}$ e $42^{\circ} \mathrm{C}$, com ativação de $2,0 \mathrm{~mm}$

Figura 5.3 - Curvas de ativação e desativação (força = função do afastamento da origem) para os fios Forestadent, GAC e Morelli, nas temperaturas de $32^{\circ} \mathrm{C}, 37^{\circ} \mathrm{C}$ e $42^{\circ} \mathrm{C}$, com ativação de $3,0 \mathrm{~mm}$

Figura 5.4 - Curvas de ativação e desativação (força = função do afastamento da origem) para os fios Forestadent, GAC e Morelli, nas temperaturas de $32^{\circ} \mathrm{C}, 37^{\circ} \mathrm{C}$ e $42^{\circ} \mathrm{C}$, com ativação de $4,0 \mathrm{~mm}$ 


\section{LISTA DE TABELAS}

Tabela 5.1 - Análise de variância das forças máximas registradas nas diversas ativações

Tabela 5.2 - Médias ( $\mathrm{g}$ ) das forças máximas dos fatores principais (ativação, marca e temperatura) e valores críticos para contrastes

Tabela 5.3 - Médias e desvios padrões das forças máximas ( $\mathrm{g}$ ) correspondentes à interação ativação $x$ marca $x$ temperatura e valor crítico para contrastes

Tabela 5.4 - Análise de variância da diminuição da força com desativação de $0,20 \mathrm{~mm}$, a partir da ativação máxima

Tabela 5.5 - Médias da diminuição da força $(\mathrm{g})$ dos fatores principais (ativação, marca e temperatura), com desativação de $0,20 \mathrm{~mm}$, a partir da ativação máxima e valores críticos para contrastes

Tabela 5.6 - Médias e desvios padrões da diminuição da força

(g) correspondentes à interação ativação x marca $x$ temperatura, com desativação de $0,20 \mathrm{~mm}$, a partir da ativação máxima e valor crítico para contrastes

Tabela 5.7 - Análise de variância da diminuição da força com desativação de $0,70 \mathrm{~mm}$, a partir da ativação máxima (3 e $4 \mathrm{~mm})$

Tabela 5.8 - Médias da diminuição da força $(\mathrm{g})$ dos fatores principais (ativação, marca e temperatura), com desativação de $0,70 \mathrm{~mm}$, a partir da ativação máxima ( 3 e $4 \mathrm{~mm}$ ) e valores críticos para contrastes

Tabela 5.9 - Médias e desvios padrões da diminuição da força

(g) correspondentes à interação ativação x marca $x$ temperatura, com desativação de $0,70 \mathrm{~mm}$, a partir da ativação máxima ( 3 e $4 \mathrm{~mm}$ ) e valor crítico para contrastes

Tabela 5.10 - Análise de variância das extensões dos platôs com ativação máxima de 3 e $4 \mathrm{~mm}$ 
Tabela 5.11 - Médias das extensões dos platôs $(\mathrm{mm})$ dos fatores principais (ativação, marca e temperatura), com ativação máxima de 3 e $4 \mathrm{~mm}$ e valores críticos para contrastes

Tabela 5.12 - Médias e desvios padrões dos platôs ( $\mathrm{mm})$, correspondentes à interação ativação $x$ marca $x$ temperatura, com ativação de 3 e $4 \mathrm{~mm}$, médias das ativações no início e final dos platôs e valor crítico para contrastes

Tabela 5.13 - Análise de variância das médias ponderadas das forças nos platôs com ativação máxima de $3 \mathrm{e}$ $4 \mathrm{~mm}$

Tabela 5.14 - Médias ponderadas das forças $(\mathrm{g})$ nos platôs dos fatores principais (ativação, marca e temperatura), com ativação máxima de 3 e $4 \mathrm{~mm}$ e valores críticos para contrastes

Tabela 5.15 - Médias ponderadas e desvios padrões das forças $(\mathrm{g})$ nos platôs, correspondentes à interação ativação $x$ marca $x$ temperatura, com ativação de 3 e $4 \mathrm{~mm}$ e valor crítico para contrastes

Tabela 5.16 - Análise de variância da desativação até registrar a força de $50 \mathrm{~g}$, a partir de 0,80 e $1,80 \mathrm{~mm}$ (respectivamente 1 e $2 \mathrm{~mm}$ de ativação) e a partir do final do platô (com 3 e 4mm de ativação)

Tabela 5.17 - Médias $(\mathrm{mm})$ para desativar até $50 \mathrm{~g}$, a partir de 0,80 e $1,80 \mathrm{~mm}$ (respectivamente 1 e $2 \mathrm{~mm}$ de ativação) e a partir do final do platô (3 e $4 \mathrm{~mm}$ de ativação), correspondentes aos fatores principais (ativação, marca e temperatura), e valores críticos para contrastes

Tabela 5.18 - Médias e desvios padrões $(\mathrm{mm})$ para desativar até $50 \mathrm{~g}$ a partir de 0,80 e $1,80 \mathrm{~mm}$ (respectivamente 1 e $2 \mathrm{~mm}$ de a tivação) e a partir do final do platô ( 3 e $4 \mathrm{~mm}$ de ativação) correspondentes à interação ativação $x$ marca $x$ temperatura, e valor crítico para contrastes

Tabela 5.19 - Análise de variância da força ao iniciar a desativação até $50 \mathrm{~g}$, em 0,80 e $1,80 \mathrm{~mm}$ (respectivamente 1 e $2 \mathrm{~mm}$ ) de ativação e a partir do final do platô (com 3 e $4 \mathrm{~mm}$ de ativação)

Tabela 5.20 - Médias das forças (g) ao iniciar a desativação até $50 \mathrm{~g}$, em 0,80 e 1,80 $\mathrm{mm}$ (respectivamente $1 \mathrm{e}$ 
$2 \mathrm{~mm}$ de ativação) e no final do platô (3 e $4 \mathrm{~mm}$ de ativação), correspondentes aos fatores principais (ativação, marca e temperatura), e valores críticos para contrastes

Tabela 5.21 - Médias das forças e desvios padrões (g) ao iniciar a desativação até $50 \mathrm{~g} \mathrm{em} 0,80$ e $1,80 \mathrm{~mm}$ (respectivamente 1 e $2 \mathrm{~mm}$ de ativação) e no final do platô (3 e $4 \mathrm{~mm}$ de desativação), correspondentes à interações ativação x marca $x$ temperatura, e valor crítico para contrastes.

Tabela 5.22 - Análise de variância do afastamento da origem ao registrar $50 \mathrm{~g}$ de força na desativação

Tabela 5.23 - Médias dos afastamentos $(\mathrm{mm})$ da origem, ao registrar $50 \mathrm{~g}$ de força, correspondentes aos fatores principais (ativação, marca e temperatura), e valor crítico para contrastes

Tabela 5.24 - Médias e desvios padrões dos afastamentos $(\mathrm{mm})$ da origem ao atingir $50 \mathrm{~g}$ de força, correspondentes à interação ativação $x$ marca $x$ temperatura, e valor crítico para contrastes

Tabela 5.25 - Análise de variância da deformação permanente ao alcançar força zero na desativação

Tabela 5.26 - Médias da deformação permanente $(\mathrm{mm})$ ao alcançar a força zero dos fatores principais (ativação, marca e temperatura), e valores críticos para contrastes

Tabela 5.27 - Médias e desvios padrões da deformação permanente $(\mathrm{mm})$ ao alcançar a força zero na desativação, correspondentes à interação ativação $x$ marca $x$ temperatura, e valor crítico para contrastes 


\section{LISTA DE ABREVIATURAS}

ADA

$A_{f}$

DERHT

DSC

MEV

$\mathrm{M}_{\mathrm{f}}$

$\mathrm{M}_{\mathrm{s}}$

SIM

T-flex

TMA

TMDSC

TR

TTR

XRD
American Dental Association

Austenite Final - Final da fase austenítica

Direct electric resistance heat treatment - tratamento térmico

por resistência elétrica direta

Diferential Scanning Calorimetry - Calorimetria diferencial de

varredura

Microscopia eletrônica de varredura

Martensite Final - Final da fase martensítica

Martensite Start - Início da fase martensítica

Stress Induced Martensite - Martensita induzida por tensão

Twist-flex, fio de aço trançado

Fio de liga de titânio-molibdênio ${ }^{\circledR}$

Temperature-modulated differencial scanning calorimetry -

Calorimetria diferencial de varredura modulada por

temperatura

Transição da fase $\mathrm{R}$

Transition temperature range - faixa de transição de

temperatura

X-Ray Diffraction - Difração de raios-X 


\section{SUMÁRIO}

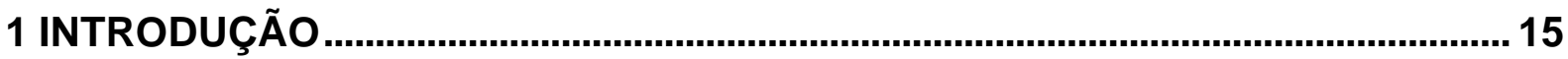

2 REVISÃO DA LITERATURA ............................................................................. 18

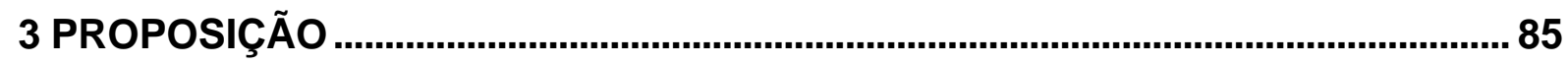

4 MATERIAL E MÉTODOS ........................................................................................ 86

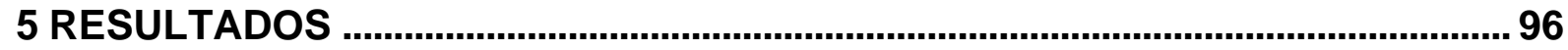

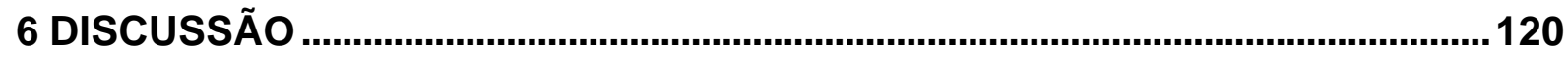

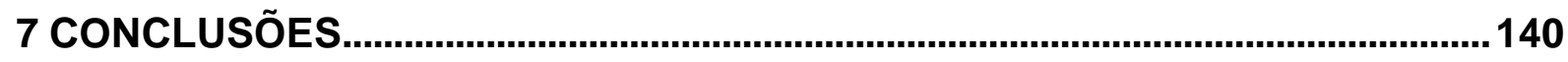

REFERÊNCIAS ...................................................................................................... 143

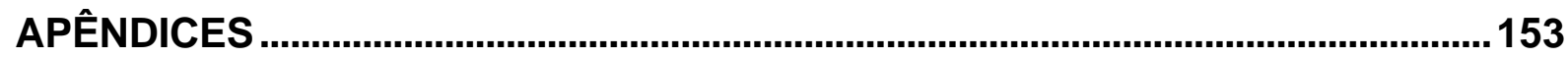




\section{INTRODUÇÃO}

Sem sombra de dúvidas, o aparecimento dos fios de ligas de níquel-titânio na Odontologia foi de extrema importância. Quando Buehler desenvolveu o chamado Nitinol e Andreasen o apresentou à classe odontológica (CHEN, ZHI, ARVYSTAS, 1992; LIPSHATZ, BROCKHURST, WEST, 1992), as mudanças que ocorreram nas técnicas de tratamento foram irreversíveis e trouxeram grandes avanços, tanto nos resultados obtidos quanto no conforto para o paciente e 0 profissional.

As características dessas ligas são tais que permitem grandes ativações com forças resultantes leves (ANDREASEN, MORROW, 1978) e constantes (KUSY, 1997). Assim, o uso de fios de níquel-titânio torna as fases iniciais do tratamento ortodôntico menos trabalhosas, na medida em que não é necessária a troca constante dos arcos de nivelamento, procedimento clássico utilizado nos tratamentos com fios de aço inox - trocam-se fios com diâmetros cada vez maiores, que, conseqüentemente apresentam crescente rigidez (ACKERMAN et al., 1978).

Forças leves também contribuem para a redução dos índices de reabsorção radicular e dor, além de reduzir o número de visitas à clínica, abreviando o tempo de tratamento.

Posteriormente, o aparecimento de ligas com propriedades ainda mais aperfeiçoadas, como a superelasticidade e a memória de forma (MIURA et al., 1986) delimitaram os procedimentos que hoje são praticamente padrão na clínica ortodôntica. Porém, as propriedades dessas ligas são ainda pouco conhecidas pelo clínico, que termina por adquirir e utilizar um material sem o completo domínio de 
suas características mecânicas. Como essas características são essenciais para que o profissional leve a bom termo o tratamento de seu paciente, sem a ocorrência de dor, reabsorções, perdas de ancoragem ou outros contratempos, o estudo das transformações alotrópicas por que passa a liga de níquel-titânio torna-se essencial para qualquer um que com ela trabalhe.

Compreender as situações em que há vantagens e desvantagens no uso de fios de ligas estabilizadas ou termoativas (GURGEL; RAMOS; KERR, 2001a) traz ao ortodontista a segurança de que estará usando o material mais indicado para uma situação específica, inclusive no que se refere a custos, visto que algumas ligas são difíceis de se encontrar no mercado, motivo pelo qual se tornam onerosas.

Apesar de que os fundamentos teóricos que embasam o conhecimento das características das ligas de níquettitânio são relativamente complexos, o estudo das transformações e dos tipos de ligas exige apenas que se compreendam as particularidades dos componentes e as formas de ligação entre os átomos que ocorrem entre eles. Assim, uma vez ciente das modificações cristalinas que podem ocorrer nessas ligações atômicas e dos estímulos que levam a essas modificações, o entendimento das mudanças de propriedades, aparentemente milagrosas, se torna claro.

Por outro lado, as inovações no campo dos tratamentos termo-químicos e das composições é constante. Autores de todo o mundo seguem pesquisando novos avanços nas propriedades de ligas para um controle cada vez maior de forma, função e desprendimento de força, o que nos leva a uma necessidade cada vez maior de compreender os mecanismos envolvidos nessas propriedades. Nada garante que o conhecimento adquirido hoje esteja atualizado amanhã, e isso se torna especialmente verdadeiro quando se tomam por exemplo questões 
econômicas ligadas ao uso de arcos pré-formados na Ortodontia. Há apenas alguns anos, era regra a conformação dos arcos imediatamente antes de sua instalação na boca do paciente. Hoje isso já não é verdade, pois com o advento de ligas com baixa formabilidade, o trabalho executado na clínica sobre o arco se tornou praticamente inviável. Assim, o profissional é obrigado a adquirir o arco já pronto, em diversas formas e dimensões, formar um estoque desses arcos para, no momento da instalação, escolher o que melhor se adaptará ao tratamento que está sendo executado. Pode-se incluir apenas pequenas modificações, normalmente no comprimento do arco, e este será amarrado aos bráquetes para cumprir sua função.

Se por um lado esse tipo de procedimento traz economia do tempo que se leva para ate nder um cliente, por outro obriga o profissional a fazer um investimento, nem sempre pequeno, em estoques. Além disso, suas opções de tratamento ficam diretamente subordinadas à variedade de formas e dimensões de arcos de que dispõe.

Ainda existem muitas dúvidas sobre o comportamento da superelasticidade dos fios ortodônticos de níquel-titânio, o que levou à consulta da literatura para maiores informações. 


\section{REVISÃO DA LITERATURA}

Para facilitar a leitura, assuntos diferentes serão abordados por tópicos.

\subsection{Generalidades e fricção dos arcos com os bráquetes}

As pesquisas sobre as forças aplicadas em tratamentos ortodônticos têm uma longa história, porém só na segunda metade do século XX os autores tiveram acesso a uma tecnologia capaz de medir com precisão as forças envolvidas nas diversas configurações dos aparelhos, bem como a novas composições de ligas para a fabricação de fios ortodônticos.

Dessa forma, Burstone, Baldwin e Lawless, (1961), afirmaram que as forças aplicadas em ortodontia só serão úteis na medida em que estimulem uma resposta tecidual desejada. Essa resposta será função da distribuição da pressão na membrana periodontal quando a força é aplicada na porção coronária do dente. As forças utilizadas nos aparelhos ortodônticos têm sua origem primária na deformação elástica dos fios, que absorvem e devolvem energia durante o carregamento e o descarregamento, assim, deve-se estar atento para algumas características de qualquer acessório ortodôntico ativo: a relação entre carga e deflexão, a carga necessária para promover deformação permanente e a amplitude do limite elástico. Apesar de que não há acessório completamente constante em sua ação, as forças desenvolvidas podem ser controladas por uma série de características de molas e fios. Concluíram que a pesquisa biológica que procura determinar os níveis ótimos de força sob condições variáveis de movimentos 
dentários implica em se ter completo entendimento do design estrutural dos elementos ativos, bem como dos processos biológicos envolvidos no movimento dentário.

Os materiais empregados para os fios ortodônticos são diversos e desde muitas décadas e ainda extensivamente nos dias atuais os mais utilizados são os metálicos. Antigamente os fios ortodônticos eram constituídos de metais nobres, que foram substituídos posteriormente em grande escala pelo aço inoxidável 18-8.

Kapila et al. (1990b) divulgaram um artigo sobre ligas ortodônticas correntemente em uso na época. Referiram-se à popularidade dos fios de aço inoxidável austenítico. Outra liga para fios ortodônticos abordada foi a de cromocobalto, que era comercializada com o nome de Elgiloy. A essa liga, em relação ao aço inoxidável, foi atribuída a vantagem de apresentar propriedades físicas superiores como resistência à fadiga e distorção. As ligas de níquel-titânio constituem outro grupo de ligas, genericamente chamadas de Nitinol. Apresentam baixo módulo de elasticidade e como característica a memória de forma. Dentro desse grupo de ligas encontram-se os fios de ligas com superelasticidade. Pode fornecer deslocamentos a forças constantes, assunto que será abordado adiante. Ainda mencionaram a liga de beta-titânio. Apresenta módulo de elasticidade bem menor (cerca de 30\%) que o aço inoxidável e maior que o Nitinol (cerca de o dobro). A liga apresenta algumas vantagens como boa resistência à corrosão, pode ser soldada por caldeamento que não altera suas propriedades.

Gurgel, Ramos e Kerr (2001a) foram outros autores que apresentaram uma divulgação sobre fios ortodônticos utilizados, entre os quais podem ser citados alguns: aço inoxidável 18-8; cromo-cobalto, inicialmente vendido com o nome de Elgiloy, protegido por patente que já venceu e atualmente existem várias marcas; 
níquel-titânio, chamado de Nitinol (o nome vem de Ni, Ti e NOL - Naval Ordinance Laboratory), apresenta características de memória de forma; mais recentemente foram introduzidos os fios de Ti-Ni, que apresentam a característica de superelasticidade ou pseudoelasticidade, que se manifesta com termoativação, nas proximidades da temperatura bucal. Podem fornecer deslocamento a força constante; os autores ainda citam fios de resina e fibra de vidro, que ainda apresentavam problemas, mas que no futuro poderão ser empregados com sucesso.

Os mesmos autores (GURGEL; RAMOS; KERR, 2001a) referiram-se ao atrito, ou resistência à fricção, que se relaciona com a força contrária imposta a um movimento. "Na ortodontia corresponde à qualidade de deslize entre o fio ortodôntico e o encaixe (slot) do acessório (bráquete ou tubo)". Esta propriedade é importante no estudo da relação força $x$ deflexão de arcos ou alças, já que a força de atrito interfere naquela disponível na mecânica ortodôntica.

Kapila et al. (1990a) visaram determinar os efeitos das dimensões dos fios e da liga na força friccional gerada entre o bráquete e o fio durante deslocamento de translação in vitro. Foram testados fios de aço inox (SS), cobalto cromo (Co-Cr), níquel-titânio e Beta-titânio (B-Ti) de diversas dimensões em bráquetes simples estreito (.050"), duplo médio (.130") e duplo largo (.180") de aço inox, tanto com slots .018" como .022". Os fios foram amarrados aos bráquetes com amarrilhos elásticos. O movimento dos bráquetes ao longo do fio foi implementado por um aparelho de testes mecânicos e as forças friccionais medidas por uma célula de compressão e registrada em um plano $x-y$. Os fios de B-Ti e níquettitânio geraram forças friccionais maiores do que os fios de SS e Co-Cr na maioria das dimensões $(B-\mathrm{Ti}=$ $177 \mathrm{~g}, \mathrm{Ni}-\mathrm{Ti}=160 \mathrm{~g}, \mathrm{SS}=89 \mathrm{~g}, \mathrm{Co}-\mathrm{Cr}=66 \mathrm{~g}$, em bráquete duplo médio). O aumento das dimensões do fio geralmente levou a um aumento na friç̧ão (de 160g para o Ni- 
Ti .016" para $192 \mathrm{~g}$ para o Ni-Ti .016" x .022"). A interação dimensão do fio-liga na magnitude da fricção foi estatisticamente significante $(p<, 005)$. Com a maioria das dimensões e ligas, o bráquete simples estreito foi associado com menores quantidades de fricção do que os bráquetes mais largos. Os níveis de fricção nos bráquetes .018" variaram de $49 \mathrm{~g}$ com o fio .016" SS no bráquete simples estreito até $336 \mathrm{~g}$ com o fio .017" x .025" ?-Ti no bráquete duplo largo. Da mesma forma, nos bráquetes $.022 "$ as forças variaram de $40 \mathrm{~g}$ com o fio .018" SS no bráquete simples, até 222 g com o fio .019” x .025" níquel-titânio no bráquete duplo largo.

A resistência friccional dos aparelhos ortodônticos é reconhecida pela maioria dos clínicos como um fator que age contra o movimento dentário. A proposta deste estudo de Pratten et al. (1990) foi comparar as forças friccionais estáticas entre bráquetes de aço inox e cerâmica. Tanto fios de níqueltitânio como de aço inox foram passados livremente pelos slots de um par de bráquetes de cada tipo. Os testes foram executados em ambientes secos e em saliva artificial. Uma carga de $300 \mathrm{~g}$ foi suspensa em cada arco para simular a força normal e uma força horizontal foi aplicada até o início do movimento para cada arco. Sob todas as condições, os bráquetes de aço inox mostraram menores coeficientes de fricção do que os de cerâmica. Os arcos de aço inox geraram menos fricção que os de níquet titânio ( $40 \mathrm{~g}$ contra $55 \mathrm{~g}$, bráquete de aço inox, seco), sendo que essa fricção aumentou na presença de saliva artificial, em comparação com o ambiente seco ( $70 \mathrm{~g}$ contra $85 \mathrm{~g}$, em bráquete de aço inox com saliva). Os resultados mostram que, sob condições experimentais, bráquetes œrâmicos, arcos de níquettitânio e saliva artificial aumentaram a resistência friccional estática.

Ho e West (1991) estudaram a força friccional dinâmica em diversas combinações arco-bráquete, com e sem lubrificação por saliva artificial, encontrando 
como resultado que a fricção diminuiu com a lubrificação com saliva e aumentou com a angulação dos bráquetes e as dimensões do arco, sem relação com a rugosidade superficial dos materiais envolvidos.

Segundo Sims, Waters e Birnie (1994), a fricção tem recebido considerável atenção na literatura recente com aparelhos fixos, apesar de que as forças atribuídas a ajustes variáveis de segunda ordem (inclinação) e terceira ordem (torque) ainda não foram totalmente esclarecidas. O estudo ex vivo de bráquetes Mini-twin, Activa e Straight Wire Standard .022" x .028" investigou a fricção quando valores conhecidos de inclinação ou torque foram aplicados a fios de aço inox $.021 \mathrm{x}$ .025". A resistência ao deslocamento do fio através do bráquete amarrado foi medida por uma máquina universal Instron. Os resultados mostraram que os bráquetes com tampa Activa produziram fricção consistentemente menor que os bráquetes convencionais. $\mathrm{O}$ aumento na inclinação e no torque (variando de $0^{\circ}$ a $6^{\circ}$ e de $0^{\circ}$ a $25^{\circ}$, respectivamente) produziram aumentos quase lineares na friç̧ão em todos os bráquetes e o efeito da lubrificação com saliva foi insignificante.

Downing, Mccabe e Gordon (1995) estudaram os efeitos da lubrificação com saliva artificial em conjuntos arco-bráquete. Concluíram que a saliva artificial aumentou a força friccional quando comparada com o experimento a seco, porém nem todos os aumentos foram estatisticamente significantes. Os autores argumentaram que água e outros líquidos polares (incluindo a saliva) podem aumentar a adesão ou atração entre materiais polares, aumentando assim a friç̧ão. Esse fenômeno ocorre por um aumento de atração atômica entre espécies iônicas e tem sido observado em diferentes materiais odontológicos, em presença de saliva, sendo explicado pela teoria da adesão e fricção. 
Kapur, Sinha e Nanda (1999) mediram e compararam os níveis de resistência friccional gerados por experimentos repetidos e não repetidos, para avaliar se o desgaste no slot do bráquete poderia influenciar na resistência friccional. Bráquetes tipo edgewise, com slots .018" e .022" foram testados em aparato especialmente projetado. A resistência foi medida em máquina universal Instron. Testes de análise de variância foram usados para determinar as diferenças entre os 10 arcos e bráquetes usados para cada combinação a fim de se comparar a influência do desgaste nas forças friccionais estática e cinética. Os resultados mostraram que há uma tendência distinta para as médias das forças friccionais serem maiores com o uso repetido dos bráquetes.

Loftus et al. (1999) compararam as forças friccionais em diversas combinações arco-bráquete, a seco. Concluíram que a fricção aumenta com a diminuição da discrepância entre as dimensões do arco e do slot do bráquete. Também verificaram que os bráquetes cerâmicos geraram fricção significantemente maior que os outros bráquetes testados, inclusive sem diferença significante entre bráquetes auto-fechantes e bráquetes comuns com ligaduras elásticas, argumentando que esse efeito se deu pela metodologia utilizada, simulando situações clínicas reais. Além disso, não encontraram diferenças significantes entre a fricção em arcos de aço inox e níquel-titânio, com uma tendência de menor fricção para esse último, talvez devido à sua maior flexibilidade.

As propriedades friccionais dos bráquetes convencionais de aço inox foram analisadas por Thorstenson e Kusy (2001), com fios de aço inox e ligaduras metálicas, comparadas com as propriedades de bráquetes auto-fechantes com os mesmos fios, em termos de angulações de segunda ordem, a seco ou lubrificados com saliva. As tampas dos bráquetes retêm passivamente o fio dentro do slot. 
Como controle, foram avaliados os mesmos bráquetes abertos, com ligaduras metálicas. A resistência ao deslizamento dos bráquetes convencionais e dos com tampa com ligaduras foi medida com forças de ligadura variando de 200 a $600 \mathrm{cN}$ e em ângulos de $-9^{\circ}$ a $9^{\circ}$. A resistência ao deslizamento dos bráquetes com tampa fechada foi medida nos mesmos ângulos, porém sem a aplicação da força da ligadura externa. Os resultados mostraram que a lubrificação com saliva aumentou discretamente a resistência friccional, quando comparada com os testes a seco.

Ainda Thorstenson e Kusy (2002) avaliaram, em, a resistência ao deslizamento do fio em 4 tipos de bráquetes auto-fechantes, com ou sem a lubrificação de saliva humana a $34^{\circ} \mathrm{C}$. Concluíram que os bráquetes auto-fechantes produzem forças friccionais mais reproduzíveis que os bráquetes de aço inox com ligaduras elásticas convencionais, com pequena tendência de aumento da resistência em presença de saliva.

A influência do tipo de ligadura nas forças de fricção durante o movimento de deslizamento ortodôntico foi estudada por Hain, Dhopatkar e Rock (2003) em condições seca e lubrificada com saliva humana, usando 4 tipos de bráquetes. Compararam as forças de fricção de módulos elásticos comuns e de um novo produto (super-slick), com amarrilhos metálicos frouxos. Seus resultados demonstram que o grau de fricção gerado pela interface módulo-fio foi afetado pelo tipo de módulo, lubrificação, tipo de bráquete e configuração da amarração. A lubrificação com saliva levou a uma redução na fricção em ambos os módulos testados, independente do tipo de bráquete. Os módulos super-slick produziram até $60 \%$ menos fricção que os módulos comuns, enquanto que as ligaduras metálicas frouxas mostraram fricção desprezível, tanto em ambiente seco como lubrificado, sem efeito na força friccional que pudesse ser atribuído à lubrificação. 
Segundo Iwasaki et al. (2003), a eficiência do movimento dentário associado a algumas mecânicas ortodônticas pode ficar comprometida pela fricção entre o arco e o bráquete. Este estudo examinou os efeitos da força de amarração $\left(F_{n}\right)$ e da mastigação na friç̧ão do deslizamento de um bráquete por um fio ortodôntico. Dados preliminares de 5 ortodontistas e 5 residentes mostraram amarrações com forças médias e com frouxas. Esses valores foram reproduzidos por um operador calibrado em um aparato usado para estimar variações nas medições de forças friccionais ex vivo e intraorais, representadas por $\mu_{a}, o$ coeficiente aparente de fricção estática. Pacientes, em número de 10, passaram a mascar chicletes com o aparato no lugar para determinar se a vibração eliminaria a fricção quando comparada com medições ex vivo. As análises demonstraram não haver diferenças significantes $(p>0,01)$ entre os valores ex vivo e intra oral $\mu_{a}$ para ligaduras de aço inox apertadas ou frouxas. Os valores intraorais para ligaduras elásticas foram significantemente maiores que os valores ex vivo $(p<0,001)$. Os resultados sugeriram que a vibração introduzida pela mastigação não elimina a fricção no movimento de deslizamento do bráquete no fio ortodôntico. Além disso, houve considerável variação intraoperador na $F_{n}$, apesar das técnicas de amarração serem bem controladas. Variações na força de amarração clínica são normalmente iguais ou maiores que as deste experimento. Essas variações podem afetar a eficiência do tratamento.

Avaliando os efeitos do método de amarração em diferentes bráquetes (com protuberâncias, ombro, arredondamentos) durante movimento de deslizamento ortodôntico, Thorstenson e Kusy (2003) concluíram que os coeficientes de fricção foram discretamente aumentados pela lubrificação com saliva na média dos bráquetes testados. As protuberâncias dos bráquetes não influenciaram 
significativamente esses resultados, porém a instalação de módulos elásticos em acessórios, fora do slot dos bráquetes, bem como a amarração com ligaduras metálicas frouxas, eliminou quase completamente a resistência ao deslizamento. O arredondamento das paredes internas do slot ajudou a diminuir as forças de fricção quando não havia folga entre o fio e o bráquete, porém nesse caso, o tipo de amarração não teve influência. Com o aumento da força normal de ligação (cerca de 200 a $800 \mathrm{~g}$ ), a resistência friccional variou de cerca de 26 a $114 \mathrm{~g}$.

O objetivo do estudo de Clocheret et al. (2004) foi avaliar o comportamento friccional de 15 tipos de fios e 16 bráquetes, usando pequenos deslocamento oscilatórios e comparando com bráquetes ou fios standard de aço inox. Os testes foram feitos de acordo com um estudo piloto com freqüência de $1 \mathrm{~Hz}$ e deslocamento recíproco tangencial de $200 \mu \mathrm{m}$, com o fio mantido centralizado no slot do bráquete sob força de $2 \mathrm{~N}$. Os resultados indicaram uma diferença significante entre os fios e bráquetes avaliados. O coeficiente de fricção médio (COF) dos fios variou de 0,16 para um fio de níquel-titânio a 0,69 para um de CoCr. Entre os bráquetes, os que apresentaram o menor COF foram os Ultraminitrim, de largura reduzida (0.39) e o menor os Master Series (0.72). Vale lembrar que as dimensões transversas dos fios eram diferentes $(.016$ " x .022" para o NiTi e .017" x .025" para o Co-Cr), assim como a largura mésio-distal dos bráquetes.

Para avaliar as forças friccionais envolvidas no deslizamento de fios ortodônticos em bráquetes, Nishio et al. (2004) utilizaram 3 tipos de bráquetes com slot .022" x .028" (cerâmico, cerâmico com slot em aço inox e bráquetes de aço inox) e 3 tipos de fios de secção retangular .019" x .025" e 4,0 cm de comprimento (aço inox, níquel-titânio e beta-titânio), em máquina de testes Emic DL 10000 com velocidade de $0,5 \mathrm{~cm} / \mathrm{min}$ por 2 minutos. A força de amarração entre o bráquete e o 
fio foi de $200 \mathrm{~g}$. Testaram também os bráquetes com angulações de $0^{\circ}$ e e $10^{\circ}$. Os resultados mostraram que o bráquete que apresentou as maiores médias de forças friccionais foi o cerâmico $(188,12 \mathrm{gf}$, com fio beta-titânio) e o que apresentou as menores médias foi o de aço inox (65,72gf, com fio de aço inox), ambos em angulação de $0^{\circ}$. Os resultados para angulações de $10^{\circ}$ mostraram as mesmas tendências. Os fios de níquel-titânio mostraram valores intermediários, com médias de 77,58gf para o bráquete de aço inox, 83,96 para o bráquete cerâmico com slot em aço inox e 85,71 para o bráquete cerâmico. Os valores tiveram diferenças estatisticamente significantes.

\subsection{Relação força/deslocamento na mecânica ortodôntica geral}

O desenvolvimento da mecânica ortodôntica de movimentação dentária, em décadas passadas, baseou-se inicialmente em fios de ligas nobres e, posteriormente, em fios de aço inoxidável, de níquel-cromo e cobalto-cromo.

Em, Andreasen (1970) discutiu a controvérsia entre aplicação de forças contínuas e intermitentes em ortodontia. Sabe-se, através de evidências histológicas, que um dente sob esforço, com ligamento periodontal normal, estimula a reabsorção do osso circundante e se torna, temporariamente, abalado. Se a força é removida o dente volta a se estabilizar com a neo formação óssea, após certo período. Os efeitos desses processos biológicos antagônicos ainda não são bem conhecidos, mas o uso de forças contínuas, que não oponham processos biológicos, tem sido recomendada para promover movimentos dentários mais rápidos, diminuir danos ao tecido ósseo, estimular reabsorção óssea direta (em oposição à 
reabsorção à distância) e um melhor suprimento sanguíneo em torno do ligamento periodontal. Forças contínuas e leves têm se provado mais efetivas em movimentar dentes do que forças pesadas e intermitentes.

Lino (1970), apresentou intensa pesquisa, abordando propriedades elásticas e plásticas de 4 formas de alça de retração ortodôntica, submetidas a tratamento térmico de recuperação em várias temperaturas e tempos. O fio empregado foi de uma liga a base de níquel-cromo, contendo carbono, magnésio, silício, fósforo e enxofre segundo o fabricante (Unitik Corporation). Das 4 formas de alça, 3 foram obtidas por prensagem em dispositivos especiais e uma foi obtida, conforme técnica clínica. As dimensões externas das alças foram altura $x$ diâmetro da curvatura (mm): longa estreita (L.E.) 9,5 x 3,3; longa larga (L.L.) 9,7 x 3,7; curta estreita (C.E.) 4,3 × 3,2; clínica $(\mathrm{Cl})$ 9,2 × 2,1. Entre muitas grandezas estudadas, mostraram interesse a força com que a alça foi fechada durante a confecção, isto é, a força necessária, apenas para separar as 2 partes da alça; as forças alcançadas dentro do "limite de proporcionalidade"; deformação elástica correspondente ao "limite de proporcionalidade". Os resultados mostraram uma série de valores interessantes. Sem tratamento térmico, as forças iniciais foram: alça C.E. - $10 \mathrm{~g}$; alça L.E. - 80; alça longa larga - 40; alça clínica - 63g. Estes valores se alteraram, conforme o tratamento térmico de recuperação: a C.E. chegou a valores negativos (até -83g), o que significa que as alças se abriram com esse tratamento; na L.E. e Cl os valores diminuíram um pouco, mas se mantiveram positivos, isto é, alças fechadas sob tensão; a L.L. chegou a ter o valor aumentado com o tratamento térmico de recuperação, conforme as condições (tempo x temperatura). O "limite de proporcionalidade", conforme a condução de tratamento térmico chegou acima de 2.000g, com a alça C.E.; cerca de $1.200 \mathrm{~g}$ com as alças L.E., L.L. e Cl. As 
deformações elásticas até o limite de proporcionalidade, conforme condições de tratamento térmico não chegaram a $1 \mathrm{~mm}$ na alça C.E., chegaram a cerca de 2,8 mm nas alças L.E. e L.L. e praticamente $1,9 \mathrm{~mm}$ na alça clínica. Uma relação ótima de tempo-temperatura foi de 6 min a $450^{\circ} \mathrm{C}$, para ser feito o tratamento térmico de recuperação das alças após a sua obtenção por dobramento.

Conley et al. (1971) se referiram a uma tabela, difícil de usar, a fim de determinar a rigidez flexural (termo segundo os autores introduzido recentemente na profissão ortodôntica na época). A tabela se referiu à relativa rigidez flexural de fios de aço inoxidável. Uma análise da tabela mostra que a relação entre os números se baseia no momento de inércia, ou seja, para outros fatores constantes, da $4^{\text {a }}$ potência do diâmetro do fio.

\begin{tabular}{|l|l|l|l|l|l|l|l|l|}
\hline Diâmetro & .008 & .010 & .012 & .014 & .016 & .018 & .020 & .022 \\
\hline .008 & 1,000 & 0,410 & 0,197 & 0,107 & 0,063 & 0,039 & 0,026 & 0,007 \\
\hline .010 & 2,441 & 1,000 & 0,480 & 0,260 & 0,152 & 0,095 & 0,062 & 0,042 \\
\hline .012 & 5,063 & 2,074 & 1,000 & 0,540 & 0,316 & 0,198 & 0,130 & 0,089 \\
\hline .014 & 9,379 & 3,841 & 1,852 & 1,000 & 0,586 & 0,366 & 0,240 & 0,164 \\
\hline .016 & 16,000 & 6,554 & 3,160 & 1,705 & 1,000 & 0,624 & 0,410 & 0,280 \\
\hline .018 & 25,629 & 10,500 & 5,063 & 2,733 & 1,602 & 1,000 & 0,656 & 0,448 \\
\hline .020 & 39,063 & 16,000 & 7,716 & 4,164 & 2,441 & 1,524 & 1,000 & 0,683 \\
\hline .022 & 57,191 & 23,426 & 11,300 & 6,100 & 3,574 & 2,231 & 1,464 & 1,000 \\
\hline
\end{tabular}

Figura 2.1 - Rigidez flexural relativa dos fios de aço inoxidável

Por exemplo, toma-se o fio .014" que se apresentar o valor de 1 , o de .010 " terá rigidez 0,260 em relação a ele ou o de .020 " terá uma rigidez de 4,164 vezes maior. Lembre-se que o módulo de elasticidade influi linearmente na rigidez, ou bem menos que o diâmetro do fio. Os autores (CONLEY et al., 1971) não muito satisfeitos com a tabela prepuseram a introdução de um dispositivo em forma circular, com peças deslizantes. Assim, consideraram que conhecido um determinado valor de um fio, facilmente pode ser determinado de outro. 
Para Waters, Stephens e Houston (1975), entre as desvantagens do uso de arcos de aço inoxidável no início do tratamento é que estes tendem a aplicar forças excessivas aos dentes, com problemas associados à movimentação dos dentes de ancoragem, além de exigirem freqüentes ajustes. Forças leves, por outro lado, permitem minimização da hialinização do ligamento, principalmente nas fases iniciais dos movimentos de inclinação dentária. Assim, determinaram algumas características físicas dos fios em uso, através de testes de recuperação elástica, podendo, com isso, determinar teoricamente outras características. Os dados apresentados mostraram que os fios torcidos ou trançados conseguem armazenar maior quantidade de energia do que os fios sólidos equivalentes $\left(0,134\right.$ e 0,078 $\mathrm{Jm}^{-1}$ respectivamente), o que demonstra a possibilidade de aplicação de forças mais leves e constantes com os primeiros.

As forças produzidas por 10 arcos ortodônticos foram medidas em uma situação clínica simulada e também com os arcos em carga simples em 3 pontos por Rock e Wilson (1988). Todos os testes foram feitos com uma deflexão máxima de 3 $\mathrm{mm}$. Para uma deflexão de $1,5 \mathrm{~mm}$, as forças exercidas quando os arcos estavam incluídos em um aparelho ortodôntico fixo variaram de 1,5 a 8,3 N. Quando os mesmos fios foram usados em testes de dobras simples, as forças exercidas variaram de 0,3 a $3,0 \mathrm{~N}$. Os resultados indicaram que as forças geradas por mecanismos ortodônticos não podem ser calculadas por princípios físicos simples.

Nikolai, Anderson e Messersmith afirmaram, em 1988, que o protocolo de testes para fios da ADA (especificação 32) não é considerado adequado para a maioria dos autores. O sistema é problemático devido a potenciais erros de uso dos componentes teóricos, incompatíveis com as novas ligas flexíveis de titânio e com os fios trançados de aço inox, que apareceram no mercado depois do estabelecimento 
da especificação. É obscuro para o clínico por ditar quantificações de propriedades mecânicas (específicas do material) ao invés de propriedades estruturais, que incluem influências da forma e dimensões do fio. Propõe-se, então, um teste de dobramento elástico em 5 pontos, que simula a ativação do fio contra um dente mal alinhado, com aparelho ortodôntico montado. Um estudo experimental foi realizado a fim de determinar os valores de rigidez transversa e o correspondente limite de elasticidade para uma série de fios ortodônticos, para avaliar o teste alternativo proposto. Neste estudo experimental usaram-se um fio de níquettitânio, um TMA e 7 de aço inox, sendo um sólido, dois torcidos, dois coaxiais e dois trançados. Os resultados dos testes mostraram que o teste alternativo proposto é válido para substituir o protocolo ora em uso pela ADA.

Proffit (2002) afirmou, em, que a forma mais simples de movimento ortodôntico é a inclinação, produzida quando uma força simples é aplicada sobre a coroa de um dente, fazendo-o girar sobre seu "centro de resistência". Dessa forma, o ligamento periodontal é pressionado próximo ao ápice radicular no lado da força e próximo à crista alveolar do lado oposto, comprimindo apenas metade da superfície do ligamento. Para um movimento de corpo (transladado), duas forças são aplicadas simultaneamente e a área total do ligamento é comprimida. Assim, o autor propõe uma tabela com as forças necessárias para produzir diversos movimentos ortodônticos: 


\begin{tabular}{l|l}
\hline Tipo de movimento & Força* $^{*}(\mathrm{~g})$ \\
\hline Inclinação & $35-60$ \\
\hline Movimento de corpo (translação) & $70-120$ \\
\hline Verticalização de raiz & $50-100$ \\
\hline Rotação & $35-60$ \\
\hline Extrusão & $35-60$ \\
\hline Intrusão & $10-20$ \\
\hline
\end{tabular}

Figura 2.2 - Forças ótimas para o movimento dentário ortodôntico. *Os valores dependem, em parte, do tamanho do dente; valores menores são apropriados para incisivos, os maiores para os posteriores multirradiculados (PROFFIT, 2002)

O objetivo de Ramadan (2004) foi determinar a influencia das concentrações de cromo e níquel na saliva e seus efeitos nos tecidos gengivais durante o tratamento ortodôntico. Para isso, 20 pacientes com idades entre 17 e 20 anos foram tratados com aparelhos fixos no arco superior durante 1 ano. De cada paciente foram coletadas 4 amostras de saliva estimulada, e foram analisadas com um espectrofotômetro de absorção atômica. Foi notada hipersensibilidade em 3 pacientes (1 masculino e 2 femininos), aumento expressivo dos níveis dos metais na saliva após 3 meses, principalmente no sexo feminino e nenhuma modificação no índice gengival. Os dados mostraram que, apesar de que a hipersensibilidade ao níquel não apresente sério risco à saúde, o ortodontista deve estar alerta para sinais desse fenômeno, assegurar-se da boa higiene bucal de seus pacientes e evitar o uso de produtos com flúor, que podem aumentar a liberação do metal no meio bucal. Verificou-se que com os fios tradicionais, a base de ligas de níquel e cromo extensivamente empregados na mecânica ortodôntica, podem conduzir a hipersensibilidade em alguns poucos pacientes.

Kusy, (2005) abordou um estudo intenso sobre a influência de sistemas de força na combinação fio-arco-bráquete. Forças ortodônticas e conexões são 
apresentadas para as 3 principais direções e planos, utilizando diagramas simplificados de princípios de equilíbrio de corpo-livre e sistemas de forças equivalentes. O autor concluiu que a análise do movimento do dente requer um entendimento fundamental das forças e conexões em espaço tri-dimensional. A resistência ao deslizamento pode aumentar ou diminuir além daquela pela força de ligação sozinha. A orientação do dente e a posição em relação ao vizinho mais próximo influenciam a rotação, angulação e torque que deve ser requerido. A superposição de movimentos dentários em direções principais e planos simplificam as análises.

\subsection{Relação força/deslocamento na mecânica ortodôntica envolvendo fios de ligas a base de níquel-titânio (Nitinol)}

Andreasen e Hilleman (1971) compararam o "limite de elasticidade" em deflexão e as taxas de carga-deflexão de dois tipos de fios Nitinol (.019" com e sem tratamento térmico) com fios de aço inox .012", .014", .016", .018" e .020" sólidos ou trançados ( $T$-flex), usando testes de rigidez com um modelo em que três dentes simulavam um desalinhamento ocluso-gengival. Os resultados mostraram que com $2 \mathrm{~mm}$ de deflexão o fio Nitinol .019" com tratamento térmico apresentou valores médios de força (1200 gf) maior que o do T-flex $.0125 "$ " (977 gf) e menor que o do fio de aço inox sólido .016" (1253 gf). Para a mesma deformação, o fio Nitinol .019" sem tratamento térmico mostrou valor médio de força bem menor (846 gf), sendo este menor que os do T-flex .0125" (977 gf), porém maior que os do fio de aço inox 
sólido .014" (753 gf). Nenhum dos fios testados mostrou indícios de superelasticidade ou memória de forma, porém os autores recomendam seu uso nos estágios iniciais do tratamento ortodôntico por seu baixo módulo de elasticidade e excelente resistência à corrosão.

O propósito de Andreasen e Brady (1972) foi sugerir o uso de dois tipos de fios Nitinol: um Nitinol 55 com TTR (transition temperature range - faixa de transição de temperatura) entre $16^{\circ}$ e $27^{\circ} \mathrm{C}(\mathrm{L})$ e outro com TTR entre $32^{\circ}$ e $42^{\circ} \mathrm{C}$ (H). Para isso analisaram as variáveis temperatura, tempo entre os intervalos de temperatura e a força gerada pelo retorno do fio em cada intervalo de temperatura em um aparelho composto por um dinamômetro e um recipiente para a colocação de areia, para gerar as forças de estiramento. As medições foram feitas na recuperação dos fios. O peso necessário para estirar os fios de 100 até $110 \mathrm{~mm}$ foi

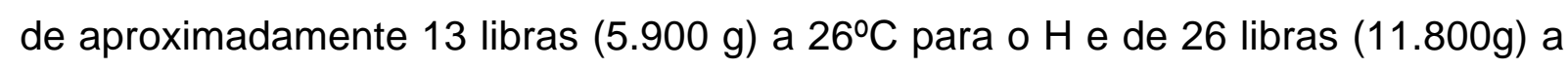
$7^{\circ} \mathrm{C}$ para L. Forças residuais nos fios fizeram-nos retornar imediatamente para aproximadamente $108 \mathrm{~mm}$. Após o estiramento o peso foi removido. Para um comprimento fixo de $108 \mathrm{~mm}$, H gerou forças de recuperação máxima de 11,3 lb (5.100g), para uma faixa de temperatura de $30^{\circ}$ a $75^{\circ} \mathrm{C}$. Na faixa compreendida entre a temperatura ambiente e a temperatura corporal, a média de força foi de 1,6 lb (725g), com um máximo de $4,8 \mathrm{lb}(2.200 \mathrm{~g})$ à temperatura corporal. O fio L apresentou, aproximadamente, as mesmas variações. Os dados indicaram que esses fios podem ser estirados em aproximadamente 7 a $8 \%$ de seu comprimento, abaixo da TTR com recuperação total, podendo ser, assim, utilizados para fechamento de espaços de extrações.

Civjan, Huget e DeSimon (1975), apresentaram alguns experimentos sobre fios de Nitinol (cerca de $55 \% \mathrm{Ni}, 1,5 \%$ Co e o restante Ti - cerca de $43,5 \%$ ). 
Estudaram a "memória de forma", associada à transformação martensítica no estado sólido de liga com aproximadamente composição equiatômica de $\mathrm{Ni}$-Ti. Fios conformados foram incluídos em revestimento e o conjunto submetido a aquecimento por uma hora a $482^{\circ} \mathrm{C}$. Esses fios foram resfriados em água gelada e depois deformados plasticamente. Em seguida colocados em meio bucal, onde os autores observaram a volta da forma existente quando fora feito o tratamento térmico a $482^{\circ} \mathrm{C}$. Os autores afirmaram que os estudos preliminares sugerem ampla aplicação da "memória de forma" desses fios. Verificaram, também, que as propriedades físicas e de "memória de forma" parecem ser sensíveis.

Verifica-se que a introdução de fios de $\mathrm{Ni}$-Ti, com "memória de forma", na ortodontia iniciou-se em meados da década de 70.

Assim, Ackerman et al. (1978) discutiram, em um painel patrocinado pelo Journal of Clinical Orthodontics, as vantagens, desvantagens e principais características e usos dos fios de níquettitânio, afirmando que: 1) O uso dos fios de níquel-titânio permite que os arcos sejam trocados menos vezes que os de aço inox, porém isso não diminui o tempo de cadeira específico para cada consulta. Apesar disso, a troca de arcos menos freqüente acaba diminuindo a necessidade de consultas freqüentes. O tempo geral de tratamento também é pouco afetado; 2) O desconforto do paciente não é menor do que com o uso de outros fios. Os fios de níquel-titânio com menores dimensões são menos agressivos do que os de maiores dimensões, como os de aço inox; 3) Incorporar dobras aos fios de níquettitânio é muito difícil, apenas são possíveis algumas pequenas dobras de primeira ordem; 4) Não é possível se fazer um tratamento ortodôntico apenas com fios de níquettitânio, a não ser que o tratamento requeira apenas alinhamento e nivelamento. Os arcos podem ser reaproveitados de um paciente para outro, porém ficam mais sujeitos a 
fraturas, que são normalmente relacionadas a tentativas de se fazer dobras ou a interferências oclusais e; 5) O custo é um fator a se levar em consideração, como em todo o material ortodôntico de boa qualidade.

Andreasen e Morrow (1978) realizaram testes de dobramento e torção em fios de níquel-titânio, comparando os resultados com os de fios de aço inoxidável. Nos testes de dobramento, o fio de níqueltitânio de secção transversal circular .018" mostrou resistência à deformação (rigidez) similar ao de aço inox .014" até um ângulo de deflexão de 35 a $40^{\circ}$ e momento de dobramento 0,1 pol.lb $(115 \mathrm{~cm} . \mathrm{g})$, quando o fio de aço começou a apresentar deformação permanente. Para um dobramento de $90^{\circ}$, o momento aplicado de 0,18 pol.lb $(230 \mathrm{~cm} . \mathrm{g})$ foi menor que o produzido por um fio de aço de .016", 0,20 pol.lb $(230 \mathrm{~cm} . \mathrm{g})$. A mesma tendência foi observada em fios retangulares. Nos testes de torção, os fios de aço inox apresentaram deformação permanente 10 vezes maior que os de níquettitânio (450ํำ contra $45^{\circ}$, após torção de $720^{\circ}$ ). Tanto no teste de dobramento como no de torção, os fios de níqueltitânio desenvolveram momentos de rotação muito menores do que os fios de aço inox, sob as mesmas condições. O módulo de elasticidade do níquet titânio é cerca de 6 vezes menor que do aço inox (34 GPa e 200 GPa, respectivamente).

O fechamento de espaços é feito tanto por translação dos bráquetes edgewise sobre o arco ou pelo uso de alças de fechamento de algum tipo. Neste trabalho, Andreasen, Bigelow e Andrews (1979) propõem um novo conceito de fechamento dos espaços, utilizando fios de níquel-titânio elásticos, que chamaram de "fios de borracha". As vantagens desse tipo de fio seriam, hipoteticamente, o alinhamento e nivelamento dos dentes concomitante com a condensação dos espaços na dentição com apenas um ou dois arcos "estirados" de níqueltitânio, com 
a faixa de temperatura de transição apropriada. A temperatura da boca faria esses fios retornarem à sua forma inicial, pré-estiramento. Um fio com o tamanho adequado deveria ter rigidez suficiente à temperatura bucal e seria mantido acima ou dentro da faixa de temperatura de transição. O sistema elimina a fricção da translação dos bráquetes e o uso de diversos auxiliares para o fechamento do espaço, além de reduzir o número de trocas de arcos, economizando também o tempo de cadeira.

Lopez, Goldberg e Burstone (1979) avaliaram fios de Nitinol e de aço inoxidável austenítico, com .018" de diâmetro, de três modos diferentes. As características de deformação permanente versus deflexão dos segmentos retos foram medidos com uma máquina Tinius Olsen de testes de rigidez, com os procedimentos recomendados pela especificação $n^{0} 32$ da ADA para fios ortodônticos. Uma segunda série de testes de dobramento foi efetuada em segmentos retos, porém ao invés das condições "instantâneas" de carga usadas no procedimento anterior, as amostras foram submetidas à carga até $60^{\circ}$ de deflexão e mantidas por $0,1,5,20,40$ ou 60 minutos e então liberadas. $O$ terceiro lote de testes considerou as características de deformação permanente versus deflexão dos fios Nitinol e aço inoxidável após dobramento permanente. As amostras inicialmente receberam dobras permanentes de $35^{\circ}$, com o cuidado para se dobrar o fio em uma única direção, usando-se um modelo para garantir a reprodutibilidade. comportamento elástico superior do fio de nitinol comparado aos fios ortodônticos convencionais de aço inoxidável têm sido claramente demonstradas com segmentos retos. Dobramentos em engastamento de amostras desses fios de até $30^{\circ}$ causam deformações permanentes insignificantes, enquanto a deflexão comparável dos fios de aço resultaram em deformações de aproximadamente $10^{\circ}$. Superioridade 
comparável, no entanto, não pode ser esperada quando os fios experimentam manipulação mais elaborada. Quando permanentemente deformados e ativados em direção oposta, os fios de nitinol na verdade mostram mais deformação permanente que os de aço, para ativações de menos de $40^{\circ}$. Clinicamente, se for necessário incorporar uma deformação permanente a um fio de nitinol, esta deve ser sobredobrada e permanentemente deformada na direção em que o aparelho será ativado. Essa técnica é similar à recomendada para fios de aço. Mesmo com essa técnica, entretanto, o clínico deve reconhecer que o nitinol, apesar de superior ao aço, não tem o grau de superioridade demonstrado por comparações feitas em secções retas, sem dobras. O nitinol parece experimentar um inesperado fenômeno de relaxamento dependente do tempo. Aumentos na deformação permanente foram pequenos na avaliação de amostras independentes por períodos de até 60 minutos. Porém, os testes realizados em 48 horas indicaram que o fenômeno de relaxamento continua por pelo menos esse período de tempo. Além disso, as amostras com histórico de deformações permanentes anteriores parecem experimentar esse efeito em grau ainda maior. Nas condições de teste utilizadas neste estudo, a deformação permanente nas amostras reutilizadas dobrou em 60 minutos, de $10^{\circ}$ para $20^{\circ}$. Isso sugere que o dobramento repetido do fio deve ser evitado. Se for usada deformação elástica ao invés de deformação permanente para comparação, o nitinol exibe 2,5 vezes a flexibilidade do aço inoxidável quando sob carga instantânea. Porém, se a carga é mantida por 48 horas, que é mais aplicável a situações clínicas, a superioridade da flexibilidade é reduzida a um fator de 2,0.

Kusy e Greenberg (1982) compararam a resistência elástica, a rigidez e os limites de duas ligas de titânio, comparadas em função da configuração dos arcos. Para tanto, utilizaram 4 arcos - dois redondos (.016" e .018") e dois 
retangulares $(.017 "$ x .025 " e $.019 "$ x $.025 ")$ - de B-titânio e 8 arcos -3 redondos $(.016 ", .018$ " e $.020 ")$, um quadrado (.018") e quatro retangulares $(.016 "$ x $.022 ", .017$ " x .025", .019" x .025" e .021" x .025”) de níquel-titânio, a partir dos quais desenvolveram equações para definir as características mecânicas de cada um. Os resultados mostraram que os fios redondos de B-titânio apresentaram quase o dobro da rigidez dos fios de níquettitânio de mesmas dimensões (0,5 contra 0,3 para o .016", 0,8 contra 0,5 no .018 " e 1,2 contra 0,7 no $.020 ")$. Para os fios quadrados e retangulares, as mesmas regras se aplicam, sendo a rigidez de um fio de níquel-titânio .018" x .018" comparável à de um de ß-titânio .016", o que sugere que com o primeiro é possível a incorporação precoce de torques no tratamento.

Segundo Hazel, Rohan e West (1984), não é adequado que a seleção dos fios em aparelhos ortodônticos seja baseada em impressões clínicas. Essa seleção deve ser feita com base em valores de força medidos dos arcos, tanto inicialmente na inserção do aparelho como durante o tempo em que o movimento dentário se realiza, com o relaxamento das tensões no fio. Assim, os autores utilizaram 5 fios de aço inox, e um de CoCr de secção transversal circular com .016" de diâmetro, dois de aço inox e um de CoCr de secção retangular .016" x .022" e dois de níquel-titânio de $.017 \times$ x.024", todos receberam um ângulo caudal de $45^{\circ}$. Os fios foram testados em um aparato especialmente construído, onde a porção posterior (angulada) do fio era presa e a parte anterior levada ao mesmo nível da posterior. Foi observada uma grande variação nas taxas de relaxamento ou manutenção das forças nos fios testados, sendo que, no geral, os fios de aço inox apresentaram manutenções menores que os de $\operatorname{CoCr}(94,8 \%$ contra $99,4 \%$ após 7 dias). Os fios de níquettitânio exibiram manutenções nos testes a $21^{\circ} \mathrm{C}(89,8 \%$ 
após 7 dias) mas não nos testes a $37^{\circ} \mathrm{C}$ (mantendo 100\%), indicando que essas ligas têm um futuro promissor como materiais para arcos ortodônticos.

A proposta da revisão publicada por Andreasen, Wass e Chan (1985) foi explicar as duas formas distintas pelas quais os fios de níquettitânio podem trabalhar, esclarecendo a confusão desses dois métodos de desempenho. A primeira forma de trabalho do fio é retornando a sua forma original como uma bola de borracha, sem exigir o uso de calor para lembrar essa forma original. Os fios de níquel-titânio retornam a sua forma original de arco após sofrerem um pequeno dobramento. Os fios que se comportam dessa forma são chamados superelásticos. Os fios superelásticos são usados na prática ortodôntica atual e não são experimentais. Outro método de desempenho é a memória de forma, em que o fio retorna à forma original quando aquecido acima de uma certa temperatura. O fio que apresenta uma alteração de forma por esse método, baseado na alteração da temperatura é chamado de níquel-titânio termodinâmico. Esses fios ainda não são usados clinicamente, mas, dependendo de futuras pesquisas, podem ser promissores para o uso clinico prático em ortodontia. Nos anos recentes, os fios de aço inox 18-8 são os fios de uso mais comum em ortodontia. Essa liga contém $18 \%$ de cromo e $8 \%$ de níquel. No início, os fios ortodônticos eram feitos de ouro. Através da historia da ortodontia, foram desenvolvidos arcos mais flexíveis (menos rígidos) e mais resilientes. No início dos anos 70, um novo nitinol (composto intermetálico equiatômico) foi desenvolvido, e não apresentava a propriedade de memória de forma. Foi chamado de fio Nitinol superelástico. Desde sua apresentação, o fio superelástico tem se mostrado útil nos tratamentos ortodônticos. Várias dimensões de fios redondos e retangulares de fios perpetuamente elásticos são fabricados atualmente. Quando usados como arcos ortodônticos, a energia 
superelástica perpétua é a característica mais distintiva dos fios Nitinol superelásticos. Mesmo quando flexionados a grandes amplitudes, eles ainda retornam a muito próximo da sua forma original exercendo forças leves para um eficiente movimento dentário. Limite de elasticidade é a medida de quanto o fio pode ser dobrado antes de sofrer deformação permanente. Um fio superelástico não temperado de 0.019" aceita pelo menos um terço a mais de deflexão sem deformação plástica do que um fio de aço inox ou T-flex de dimensão comparável. Como resultado desse maior limite de trabalho dos fios de níquel-titânio, os slots dos bráquetes de dentes severamente mal posicionados podem ser facilmente alcançados no tratamento pelo arco.

Essa grande flexibilidade a que os autores se referem provavelmente é devida ao bem menor módulo de elasticidade. Ainda o que chamam de superelasticidade, parece não ser exatamente o que atualmente se entende por essa característica.

Burstone, Qin e Morton (1985) estudaram o fio de níquel-titânio Chinês com um teste de dobramento para determinar sua rigidez, efeito mola e momento máximo de dobramento. O fio de níquel-titânio Chinês tem uma curva de desativação pouco comum (diferente dos fios de aço inox e Nitinol) em que forças relativamente constantes são produzidas por uma longa faixa de ativação. A rigidez flexural característica dos fios de níquel-titânio é determinada pela quantidade de ativação. Em grandes ativações, os fios de níquel-titânio têm uma rigidez flexural de apenas $7 \%$ de um fio de aço inox comercial, e em pequenas ativações, $28 \%$ desse fio de aço. Para a mesma ativação em grandes deflexões, as forças produzidas são $36 \%$ comparativamente às de um fio Nitinol. O fio de níquel-titânio Chinês demonstra efeito mola fenomenal. Ele pode ser flexionado 1,6 vezes mais que um 
fio Nitinol ou 4,4 vezes mais que um de aço inox sem mostrar deformação permanente apreciável. O fio de níqueltitânio é largamente usado em situações clinicas que exigem baixa rigidez com efeito mola extremamente grande.

Miura et al. (1986) apresentaram um novo fio de níquettitânio Japonês, desenvolvido pela Furukawa Eletctric Co. Ltd. do Japão. Esse fio foi submetido a testes de tração uniaxial e testes de dobramento em três pontos especialmente desenvolvidos para determinar a rigidez e avaliar o efeito de mola, efeito memória e superelasticidade do fio. O fio Japonês mostrou uma propriedade incomum chamada "superelasticidade", que não se encontra em nenhum outro fio ortodôntico. Esse fenômeno foi pesquisado a fundo. O fio fornece força constante em uma extensa faixa da curva de desativação. Entre todos os fios comparados, o fio Japonês de níquel-titânio foi provavelmente o que menos deformação permanente apresentou durante a ativação. A nova liga exibiu uma curva tensão-deformação específica, diferente de outros materiais testados. A tensão permaneceu praticamente constante, a despeito da alteração da deformação em uma faixa específica. Esse atributo único é a manifestação da superelasticidade. O tratamento térmico permitiu uma magnitude de carga em que a superelasticidade pode ser induzida e controlada, tanto pelo tempo como pela temperatura. Um processo único e útil foi também desenvolvido em que um arco pode desenvolver várias magnitudes de força para uma dada ativação com o mesmo diâmetro. As aplicações clínicas dessa nova liga podem gerar um movimento dentário mais fisiológico, devido à força relativamente constante desprendida por um longo período de tempo durante a desativação do fio. A liga de $\mathrm{Ni}$-Ti Japonesa pode ser considerada uma importante adição de material à metalurgia ortodôntica clínica. 
Segundo Ingram, Gipe e Smith (1986), a especificação da ADA nº 32 para determinação do limite de elasticidade de fios ortodônticos usa testes de dobramento de segmentos dos fios engastados em uma das extremidades.

Um método alternativo para a definição dos intervalos dos fios proposto por Waters (1981), consiste em enrolar segmentos do fio em mandris de variados diâmetros e medir a deformação residual após o desenrolamento. Quatro mandris, cada um com vários diâmetros, variando de 3,5 a 60,0 mm (total de 46 diâmetros de teste) foram usados neste estudo. Os segmentos de fios de $9 \mathrm{~cm}$ de comprimento foram enrolados nos mandris em um torno manual. A secção transversal do mandril necessária para produzir uma quantidade pré-determinada de deformação (um arco de $2 \mathrm{~mm}$ de altura em uma corda de $5 \mathrm{~cm}$ ) foi definida como "diâmetro de deformação" para aquele fio em particular. As amostras de 488 diferentes fios ortodônticos de 9 fabricantes foram avaliadas (total de 4.747 espécimes). Fios de aço inox de dimensões idênticas apresentaram grande variação nos limites, dependendo da quantidade de trabalho a frio e do tratamento térmico. Por exemplo, um fio redondo .020" apresentou diâmetros de deformação entre 22,8 mm e 42,9 $\mathrm{mm}$. Os fios de CrCo tiveram menos variação que os de aço inox antes do tratamento térmico, mas essa variação aumentou muito depois desse tratamento. Os fios Nitinol tiveram as maiores variações de todos os fios testados.

Deformação e comportamento de transição associada com a fase $\mathrm{R}$ (fase romboédrica) de ligas de Ti-Ni foram investigados por Miyazaki e Otsuka (1986). Referiram-se ao fato de que o comportamento de deformação associado à transição da fase $R$ e à subseqüente transformação martensítica tem sido estudado sistematicamente, nas ligas de Ti-Ni, por ensaios de tração ao longo de um intervalo de temperatura, desde $M_{f}$ até acima de TR $\left(>A_{f}\right)$. As características de 
transformação e transição mostraram intensa dependência de tratamento termomecânico e conteúdo de níquel, o que levou ao emprego da microscopia eletrônica para estudar a estrutura. Como resultado precipitados e ou deslocamentos foram revelados em espécimes em que ocorria a transição da fase $R$.

Kusy e Stevens (1987) determinaram as propriedades elásticas de 16 fios de aço trançados e comparadas entre si, bem como com as propriedades de fios de níquel-titânio com aplicação clínica similar. Os resultados experimentais mostraram que as proporções das propriedades elásticas dos fios trançados variaram muito, e que estes se compararam favoravelmente com alguns dos onerosos fios de ligas de titânio. O cálculo dessas proporções envolveu as dimensões físicas e as propriedades mecânicas dos fios. O diâmetro geral medido dos fios foi muito próximo ao alegado pelos fabricantes. Os ângulos das hélices variaram de $60,5^{\circ} \mathrm{a}$ $79,5^{\circ}$. O valor médio de $198 \mathrm{GPa}(28,7 \mathrm{Msi})$ para o módulo de elasticidade foi independente das dimensões do fio. A computação das relações elásticas mostrou que o fio trançado $.0150 "$ foi o menos rígido. Nenhum outro fio pode se comparar quando se exigem grande amplitude e forças leves. Por outro lado, o Nitinol .016" é de 20 a 40\% mais rígido, mas possui maior resistência e amplitude que todos os fios trançados .0175", menos os produtos da Unitek. No geral, o fio trançado .0195" da Unitek é similar ao Nitinol .018".

Harris, Newman e Nicholson (1988) estudaram as alterações nas propriedades mecânicas das ligas de níquel-titânio, nitinol (arcos ortodônticos redondos .016") em um ambiente oral simulado com vários níveis de acidez e em diferentes quantidades de deflexão estática. Foram observadas significantes diminuições nas propriedades mecânicas especificas desses fios incubados, comparados com um grupo mantido como controle. A acidez ( $\mathrm{pH}$ de 3 a 7) e a 
quantidade de deflexão ( 0 a 4 mm em um comprimento de $10 \mathrm{~mm}$ ) não afetaram os fios, mas houve significante diminuição da resistência ao dobramento com o tempo, no ambiente oral simulado. Em 4 meses, a medida da susceptibilidade à deformação permanente aumentou em $15 \%$. Conseqüentemente, o uso a longo prazo (ou a reutilização) dos arcos de níquettitânio pode ser associado a essa modesta, mas estatisticamente significante, degradação do desempenho, principalmente no limite de elasticidade do arco.

Lee et al. (1988) realizaram um estudo preliminar para demonstrar a utilidade de uma técnica combinada de calorimetria diferencial de varredura (Diferential Scanning Calorimetry - DSC) e testes mecânicos para metais com memória de forma de ligas com 54NiTi e 53NiTiCo (3\%). A técnica DSC foi usada para medir com precisão as temperaturas e a quantidade de energia térmica necessária para a correspondente transformação de fase. Os resultados indicaram que a temperatura de transformação martensítica $\left(\mathrm{M}_{\mathrm{s}}\right)$ das ligas $54 \mathrm{Ni}-\mathrm{Ti}$ e $53 \mathrm{Ni}-\mathrm{Ti}$ ficou próxima à temperatura ambiente. A adição de Co à liga diminuiu a temperatura de transformação austenítica $\left(A_{s}\right)$ de $36,8^{\circ} \mathrm{C}$ para $9,6^{\circ} \mathrm{C}$ com dobramento de $0^{\circ} \mathrm{e}$ aumentou o momento de dobramento (de 4,86 a 6,67 $\mathrm{N} ? \mathrm{~m} \times 10^{-3}$ ) em temperatura ambiente $\left(23\right.$ a $\left.26^{\circ} \mathrm{C}\right)$, resultando também em mais baixa energia de transformação.

O mecanismo de memória de forma associado à transição da fase $\mathrm{R}$ (fase romboédrica) foi analisado por Miyazaki e Wayman (1988), empregando monocristais de níquettitânio. Foram realizados testes de tração e observações microscópicas in situ. Foram encontradas quatro variantes distintas da fase R, podendo ser correlacionadas umas com as outras por pareamento. Seis planos de pareamento foram determinados em cada variante usando análise bi-superficial. Uma morfologia especifica consistindo dos quatro tipos de variantes da fase $\mathrm{R}$ foi 
formada durante o resfriamento abaixo do ponto TR. A combinação das quatro variantes produziu deformação macroscópica zero, indicando que a morfologia específica é resultado de auto acomodação. Sob tensão, a variante mais favorável da fase $\mathrm{R}$ foi formada das variantes remanescentes por deformação pareada. No aquecimento após o descarregamento, o espécime mostrou recuperação de forma que é função da temperatura ou do ângulo romboedral da fase R. A maior parte da recuperação de forma se deu por alteração no parâmetro reticulado da fase $R$, mas não por transição reversa. A maneira como se deu a recuperação de forma é diferente daquela associada à transformação martensítica reversa. Com base nos resultados obtidos, o mecanismo de memória de forma associado à transição da fase $R$ nas ligas de níquel-titânio foi esclarecido.

Miura, Mogi e Ohura (1988) apresentaram um método para configuração de forma e controle dos níveis de força superelástica dos fios de níquel-titânio japoneses, consistindo de um aparelho de DERHT (tratamento térmico por resistência elétrica direta), que faz passar uma corrente elétrica pelo fio gerando calor suficiente para o tratamento térmico adequado. Esse método permite que se executem dobras no fio e controle da força. Para testá-lo, utilizaram fios de níquet titânio de 5 diâmetros diferentes .014", .016", .018", .020" e .022" e para comparação, fios de aço inox, $\mathrm{CoCr}$ e níquettitânio trabalhado a frio. Os fios de níqueltitânio Japonês foram dobrados com o sistema DERHT e os outros normalmente, e os resultados demarcados em papel gráfico. O resultado da dobra depende do tempo e da amperagem da corrente elétrica. Para um fio de .016", 1,0 segundo de tratamento requer uma corrente de 5,5 $\mathrm{A}$, ao passo que um tratamento de 5,0 segundos pode ser feito com uma corrente de 3,5 A. Quanto menor o diâmetro do fio, também será menor o tempo e a corrente necessários. Assim, o 
método se mostrou eficaz no dobramento e no controle da força superelástica dos fios, desde que aplicados a corrente e o tempo corretos para cada dimensão de fio.

Kapila e Sachdeva (1989), em artigo de revisão, descreveram as propriedades mecânicas e aplicações clínicas de fios ortodônticos de aço inox, CoCr, níquettitânio, beta-titânio e T-flex. As propriedades desses fios são, geralmente, analisadas através de testes de tração, dobramento e torção. Apesar de que as características determinadas por esses testes não refletem necessariamente o comportamento dos fios sob condições clínicas, eles fornecem uma base para comparações dos fios. As características desejáveis em um fio ortodôntico são bom efeito mola, baixa fricção superficial e a capacidade de ser unido ou soldado. Fios de aço inox continuam populares desde sua apresentação aos ortodontistas, devido a sua formabilidade, biocompatibilidade e estabilidade ambiental, rigidez, resiliência e baixo custo. Fios de Co-Cr podem ser manipulados em um estado amaciado e, então, submetidos a tratamento térmico. O tratamento térmico desses fios resulta em um fio com propriedades similares às dos fios de aço inox. Fios tipo Nitinol têm bom efeito mola e baixa rigidez, características importantes em circunstâncias que exijam grandes deflexões com baixos níveis de força, possuindo maior energia de recuperação do que os fios de aço inox e beta-titânio quando ativados aos mesmos níveis de dobramento ou torque. Da mesma forma, fios de ligas de Ni-Ti produzem forças mais constantes em diferentes níveis de ativação, do que fios de outras composições. Essas ligas, entretanto, apresentam pouca formabilidade e soldabilidade. Fios de beta-titânio combinam efeito mola adequado, rigidez moderada, boa formabilidade e podem ser soldados. Fios tipo Twist-Flex têm alto efeito mola e baixa rigidez, quando comparados com fios de aço inox sólidos. O uso otimizado desses fios ortodônticos pode ser feito pela seleção criteriosa do tipo e 
dimensão apropriados do fio que atendam às demandas de uma situação clínica particular.

Hurst et al. (1990) analisaram quantitativamente o fenômeno de memória de forma de 7 fios comerciais de níquettitânio. A memória de forma foi determinada pelo cálculo da percentagem de recuperação de forma ocorrida quando cada fio foi inicialmente deformado plasticamente abaixo de sua temperatura TTR e então aquecido acima dessa temperatura. Os resultados indicaram que: 1 - a percentagem média de recuperação de forma ficou na faixa de $89 \%$ a $94 \%$ para os fios Ni-Ti, Nitinol, Orthonol, Titanol, Sentinol Light e Sentinol Médium. O fio Sentinol Heavy mostrou recuperação média de $41,3 \%$, que foi significantemente menor que das outras ligas; 2 - parece que o fio Sentinol Heavy mostrou relativamente menor percentagem de recuperação porque sua TTR é próxima à temperatura ambiente. Isso resultou em mínima deformação plástica, pois o fio retornou à sua forma original quase imediatamente, indicando a importância da TTR. Concluiu-se que a TTR deve ser razoavelmente mais alta que a temperatura bucal para aplicação clinica do fenômeno de memória de forma para fios de níquettitânio e; 3 - a temperatura de recuperação de forma foi mantida em $300^{\circ} \mathrm{F}\left(149^{\circ} \mathrm{C}\right)$ neste estudo para se obter o máximo de recuperação possível. Apesar de que os resultados indicam que a recuperação foi de cerca de $90 \%$ para a maioria das ligas testadas, futuros estudos são importantes para se determinar o efeito de recuperação de forma à temperatura bucal ou pouco acima desta.

Oito materiais para fios ortodônticos foram estudados por Kusy e Wilson, (1990): uma liga ortodôntica de titânio-molibdênio (Ti-Mo, TMA), três de níquel-titânio (Nitinol, Titanal e Orthonol), três ligas protótipo sendo uma martensítica, uma austenítica e uma bi-fásica com efeito de memória de forma, e um produto híbrido 
com efeito de memória de forma, o Biometal. Cada fio foi preparado com um comprimento de 3600 vezes a área da secção transversal e analisada com um Autovibron Modelo DDV-II-C no modo de tração, de -120 a $+200^{\circ} \mathrm{C}$ a $2^{\circ} \mathrm{C} / \mathrm{min}$. A partir desses dados, foram gerados gráficos de vários parâmetros. Os resultados mostraram que as propriedades mecânicas dinâmicas das ligas desses sistemas de Ti são muito diferentes. A liga TMA não variou com a temperatura, tendo um módulo de elasticidade de $10,6 \times 10^{6}$ psi (73 GPa). As três ligas de níquel-titânio trabalhadas a frio parecem ser similares entre si, com módulo de $8,32 \times 10^{6}$ psi (57 GPa), enquanto que a liga bi-fásica mostrou transformação de fase próxima à temperatura ambiente e o produto híbrido sofreu uma alteração em comprimento de $3-5 \%$ durante sua transformação entre 95 e $125^{\circ} \mathrm{C}$. Entre os fios de níquel-titânio testados, diversos tipos diferentes de ligas foram representadas por esse material intermetálico.

O trabalho de Miura, Mogi e Okamoto (1990), afirmou que um novo fio retangular de níquel-titânio (Neo Sentalloy) pode ser usado com forças extremamente suaves na fase inicial do tratamento. Isso significa que pode se conseguir controle tridimensional do dente (incluindo torque de raiz) ao mesmo tempo em que se executam o alinhamento e o nivelamento. A curva de cargadeflexão desse novo fio mostra força contínua extremamente baixa (entre 100 e 300 g, dependendo do tipo do fio), a despeito da deflexão. Demonstraram que a força superelástica pode ser aplicada em baixo nível, independentemente das dimensões do fio. Assim, é possível se obter controle tridimensional do movimento dentário, incluindo torque, já nos primeiros estágios do tratamento ortodôntico. Com o tratamento térmico, o fio superelástico não só muda seu nível de força, mas memoriza formas. Essa ultima característica torna possível se condicionar um arco 
de forma que este memorize uma determinada posição, incluindo torque, angulações e movimentos vestibulo-linguais. O arco pode, então, ser modelado no laboratório previamente, ao invés de se utilizar precioso tempo de cadeira. A forma do arco será também mais precisa do que se for moldado na clínica.

Os fios de níquettitânio chineses são comparados com o Nitinol e os fios de aço inox por Mohlin et al. (1991), em um exame combinado, clínico e de laboratório. No teste de laboratório foram determinadas as propriedades de carregamento e descarregamento dos fios em um teste de dobramento em três pontos, e suas propriedades superficiais estudadas em microscópio eletrônico de varredura. Esses testes procuram simular uma situação clinica comum. Os fios chineses de níquel-titânio mostraram comportamento carga-deflexão não linear. O aumento de força até $1 \mathrm{~mm}$ na deflexão foi razoável, mas, daí em diante foi muito pequeno e a força liberada durante o descarregamento a partir de grandes deflexões foi praticamente constante, ficando em cerca de 100gf. Esse comportamento foi um tanto diferente para pequenas deflexões nos fios de níquettitânio. A deformação plástica foi insignificante. O estudo clínico confirmou os resultados obtidos em laboratório, caracterizando o fio Chinês como muito superior ao aço inox e mesmo ao Nitinol para fins de alinhamento. No uso clínico, entretanto, a taxa de fraturas desses fios se mostrou insatisfatoriamente alta. Essa desvantagem não foi prevista no teste de dobramento em três pontos. A MEV revelou defeitos superficiais e inclusões não metálicas nos fios fraturados. Recomendaram a combinação de testes de laboratório, simulando situações clinicas e exame superficial quando um novo material for testado.

Yoneyama et al. (1992) apresentaram uma investigação sobre a superelasticidade e comportamento térmico de 20 fios de ligas de $\mathrm{Ni}$-Ti, para arcos 
ortodônticos. Empregaram o ensaio de dobramento de três pontos e verificaram substancial diferença entre as curvas de força em função da deflexão. Alguns fios apresentaram superelasticidade, quando a força diminuía pouco com a diminuição da deflexão. Outros mostraram apenas propriedades de mola e a carga era aproximadamente proporcional à deflexão. Com alguns fios de comportamento superelástico, com deflexão de $2 \mathrm{~mm}$ as cargas chegaram a cerca de 220 e $280 \mathrm{~g}$ e os platôs no descarregamento ocorreram em torno de 60 a $150 \mathrm{~g}$, conforme o fio. O comportamento térmico, devido à transformação de fases na liga, foi avaliado pela calorimetria diferencial de varredura. Alguns fios não apresentaram temperaturas de transformação adequada, a fim de manifestarem superelasticidade à temperatura do corpo humano. Além do mais, o comportamento térmico estava intimamente relacionado com a superelasticidade. Foram encontrados nitidamente picos térmicos nas curvas obtidas com os fios de superelasticidade. Já com os fios sem superelasticidade não foram encontrados picos térmicos nas respectivas curvas.

Angolkar et al. (1992) tiveram como objetivo determinar a degradação de força de molas helicoidais fechadas, feitas de aço inox (SS), Co-Cr-Ni e níquel-titânio (NiTi), quando ativadas para gerar valores de força iniciais na faixa de 150 a $160 \mathrm{~g}$. Os espécimes foram divididos em dois grupos. O grupo I incluiu SS, Co-Cr-Ni e dois tipos de molas de níquel-titânio (NiTi1 e NiTi2), de .010" x .030" com comprimento inicial de $12 \mathrm{~mm}$. O grupo II era composto por SS, Co-Cr-Ni e uma terceira mola de níqueltitânio (NiTi3) com .010" x .036" e comprimento inicial de 6 mm. Um estudo piloto determinou a extensão requerida para cada tipo de mola, de forma que a força inicial estivesse na faixa de 150 a $160 \mathrm{~g}$. As molas foram deixadas ativadas por $4 \mathrm{e}$ 24 horas e 3, 7, 14, 21 e 28 dias, resultando em um total de 8 períodos de tempo. Entre os intervalos de tempo, todas as molas foram estendias ao mesmo 
comprimento inicial e armazenadas em saliva artificial a $37^{\circ} \mathrm{C}$. Todas as molas mostraram perda de força com o tempo. Do total, a maior perda de força para a maioria das molas ocorreu nas primeiras 24 horas. As molas SS e Co-Cr-Ni mostraram diminuição de força relativamente maior no grupo I, comparadas com as molas de níquettitânio. As molas NiTi3 do grupo II mostraram maior degradação de força que as SS e Co-Cr-Ni nesse grupo. A menor diminuição de força se deu nas molas NiTi1. no geral, o total de perda de força nos 28 dias ficou na faixa de $8 \%$ a $20 \%$ para todas as molas testadas.

Chen, Zhi e Arvystas (1992), apresentaram os resultados de uma investigação, onde compararam fios ortodônticos de Ni-Ti Chinês com outros seis fios de níquel-titânio. Também apresentaram várias aplicações clínicas ortodônticas desse fio Chinês de Ni-Ti. Algumas das conclusões foram: 1) o fio de Ni-Ti Chinês demonstrou $100 \%$ de recuperação em dobramento com ângulo de 90 com espécimes de $12,5 \mathrm{~mm}$ de comprimento e de $19 \%$ de deformação permanente em teste de torção de $720^{\circ}$ em espécime de $25,4 \mathrm{~mm}$ de comprimento; 2) o fio de $\mathrm{Ni}-\mathrm{Ti}$ Chinês demonstrou excelente retenção de memória; 3) o fio de Ni-Ti Chinês apresentou um grande intervalo constante de momentos de dobramento e de torção, isto é, oferece forças quase constantes, o que é desejável em tratamento ortodôntico; 4) o fio de Ni-Ti Chinês possui baixa rigidez alto efeito de mola e superelasticidade; 5) na prática clínica o fio de Ni-Ti Chinês mostrou sucesso no tratamento de várias más-oclusões. É capaz de manter baixa e quase constante força.

Lipshatz, Brockhurst e West (1992) lembraram, também, que o Nitinol foi desenvolvido nos anos 60 no programa espacial da NASA, por Buehler. O nome é um acrônimo derivado dos elementos que compõe a liga: Ni para níquel, Ti para 
titânio e NOL para Naval Ordinance Laboratory. O Nitinol apresenta duas características únicas: excelente elasticidade quando estirado em fios de alta resistência e memória de forma. A memória de forma em um metal é a característica pela qual uma deformação plástica produzida a uma determinada temperatura pode ser recuperada acima de uma temperatura maior, conhecida como temperatura de transição. As propriedades físicas vantajosas para o clínico são o baixo módulo de elasticidade, resistência considerável e larga faixa de trabalho. Essas características permitem ao clínico aplicar uma força quase constante por uma amplitude de deslocamento muito maior do que previamente possível. Enquanto os fios Nitinol trabalhados a frio têm sido largamente utilizados como fios de alta resistência e baixo módulo de elasticidade, suas propriedades termodinâmicas não foram utilizadas até o advento do fio de níquettitânio Japonês, com temperatura de transição próxima à temperatura bucal. Esses fios também possuem superelasticidade, que é definida como uma tensão constante por uma grande extensão de desativação. Quatro diferentes tipos de fios ortodônticos foram avaliados pelos autores para determinar seu comportamento em dobramento. Foram avaliados o fio Japonês, o Nitinol, Tflex e um fio de aço inox. Foi usado um teste de dobramento em 3 pontos com três deflexões diferentes (1, 3 e $5 \mathrm{~mm}$ ) sob diferentes temperaturas $\left(24^{\circ} \mathrm{C}\right.$ e $\left.37^{\circ} \mathrm{C}\right)$. Todos os fios de memória apresentaram superelasticidade no descarregamento, com uma pequena diminuição dos níveis de força com uma substancial diminuição na deflexão. O fio Japonês mostrou o menor módulo de elasticidade - $1422 \mathrm{MPa}$ na região superelástica - no gráfico forçadeflexão, de todos os fios testados. Os níveis de força nessa região variaram de 1,26 a $0,76 \mathrm{~N}$ (123 a 74g). Esse nível de força é consistente com os níveis de força reconhecidos como ótimos para o movimento dentário. O fio Nitinol mostrou rigidez 
não uniforme maior que o fio Japonês na maior parte da curva de descarregamento. Os níveis de força gerados pelo fio no descarregamento foram excessivos, exceto em pequenas deflexões (menos que 0,6 mm). A fricção parece ser bem mais importante nas características de desenvolvimento de força do Nitinol do que nos outros fios. O módulo de elasticidade do T-flex foi de $2860 \mathrm{MPa}$ e foi constante durante toda a curva de descarregamento. O efeito da diminuição da temperatura de 37 para $24{ }^{\circ} \mathrm{C}$ nos fios de memória foi uma diminuição geral nos níveis de força. Foi notada uma deformação plástica no fio Japonês a $24^{\circ} \mathrm{C}$, que pode ser revertida pelo aquecimento à temperatura bucal. Com base nesses resultados iniciais, tanto 0 fio Japonês como o T-flex podem ser considerados para uso como fios iniciais de nivelamento. Ambos os fios têm baixo modulo de elasticidade, excelente resistência e amplitude elástica, suficiente para a maioria das situações clinicas. Ambos são fios retangulares e permitem controle de torque a partir do início do tratamento.

Para Waters (1992), os fios ortodônticos superelásticos de níquel-titânio, ao contrario dos fios convencionais, são capazes de resistir a grandes deflexões produzindo em seu retorno à forma original uma força mais moderada. A região da curva carga-deflexão em que há um platô depende da deflexão e será maior quanto maior for essa deflexão. Com a maioria dos fios, tanto a resistência inicial ao dobramento como o nível de carga do platô de desativação dependem muito da temperatura. As dimensões do fio não são mais uma referência para o comportamento dos valores de força do fio em uma dada temperatura, e para fios do mesmo diâmetro nominal, de diferentes fabricantes, esses valores podem variar em até 6 vezes.

O objetivo do estudo de Han e Quick (1993), foi determinar se as propriedades mecânicas de molas de $\mathrm{Ni}$-Ti são afetadas por exposição prolongada a 
um ambiente oral simulado estático. Para comparação, foram também incluídas no estudo molas de aço inox e cadeias elásticas de poliuretano. As molas foram estiradas até o dobro de seu comprimento inicial em repouso e assim mantidas imersas em saliva artificial à temperatura corporal por $0,2,4$ ou 6 semanas. Os resultados mostraram que as molas de $\mathrm{Ni}$-Ti não sofreram degradação de suas propriedades no ambiente oral simulado, enquanto que as molas de aço inox sofreram discreta diminuição da força e os elásticos de poliuretano perderam grande parte de sua capacidade de gerar forças.

Nardi, Gambarini e Tosti (1993) enfatizaram a necessidade de análise de diversos produtos propostos pelos fabricantes. Com respeito aos fios ortodônticos, uma avaliação adequada de suas propriedades mecânicas é bem vinda, para adequá-los ao uso clinico. Após breve revisão das propriedades mecânicas dos fios comerciais, os autores observaram os fios $\mathrm{Ni}-\mathrm{Ti}$ japoneses superelásticos. Fizeram, assim, uma avaliação dos aspectos falhos dos arcos pré-formados de níquel-titânio com secção circular .018". Os fios testados se destinam ao uso clinico como os primeiros fios de nivelamento, e foram avaliados após 8 semanas do inicio da terapia, quando mostraram falha no controle na $8^{\mathbf{a}}$ semana. Após limpeza e preparação dos espécimes, as zonas de falha foram observadas ao MEV. O aspecto das falhas foi avaliado para se verificar os motivos que as produziram, baseado nas características da superfície. O aspecto da superfície na falha e a ausência de deformação permanente mostraram que é uma falha por fragilidade. Essas falhas ocorrem quanto o material não consegue tolerar deformações plásticas, típico dos fios de níqueltitânio testados, unindo comportamento superelástico e alta resiliência. Isso significa que o fio pode produzir forças leves e contínuas por uma dada faixa de tensão, sendo capaz de absorver energia sem deformação 
permanente. Desde 1971, os fios de níquel-titânio têm sido comercializados, mas sem as propriedades superelásticas e cristalográficas de memória de forma dos fios produzidos pela Furukawa El. Co. em 1978. Esses fios, em altas temperaturas, mostram uma configuração cristalográfica CCC (cúbica de corpo centrado), conhecida como fase beta (fase austenítica), enquanto à temperatura ambiente possuem uma reticula hexagonal compacta, conhecida como fase alfa (fase martensítica). A fase martensítica mostra claras vantagens como a rigidez reduzida, campo de ação aumentado e flexibilidade aumentada, porém também apresenta desvantagens específicas. Assim, a necessidade de direcionar o uso clínico desses fios para o início do alinhamento e/ou correções de rotações, onde não se notam situações de particular esforço mastigatório, é verdadeira. Essas situações são típicas de pacientes braquicéfalos, em que a musculatura mastigatória é particularmente desenvolvida.

Yoneyama et al. (1993) investigaram o efeito da temperatura do tratamento térmico nas propriedades de dobramento e nas temperaturas de transformação de um fio de níquel-titânio com 1,0 mm de diâmetro, para uso em aparelhos ortodônticos que necessitem memória de forma. O tratamento térmico foi efetuado a $713 \mathrm{~K}\left(440^{\circ} \mathrm{C}\right)$ por $1,8 \mathrm{ks}(30 \mathrm{~min})$ e entre $673 \mathrm{~K}\left(400^{\circ} \mathrm{C}\right)$ e $813 \mathrm{~K}\left(540^{\circ} \mathrm{C}\right)$ por $1,8 \mathrm{ks}$ (30 min). Foram efetuados testes de dobramento em três pontos e calorimetria diferencial. As temperaturas de transformação dos fios foram diminuídas com o aumento da temperatura do tratamento térmico. A temperatura final de transformação reversa ficou abaixo da temperatura corporal com o tratamento acima de $753 \mathrm{~K}\left(480^{\circ} \mathrm{C}\right)$. A deflexão residual do arco de níquel-titânio após dobramento foi pequena com o tratamento térmico secundário acima de $733 \mathrm{~K}$ $\left(460^{\circ} \mathrm{C}\right)$. Os valores de descarregamento foram menos afetados e aumentaram com 
a temperatura de tratamento entre $733\left(460^{\circ} \mathrm{C}\right)$ e $813 \mathrm{~K}\left(540^{\circ} \mathrm{C}\right) . \quad \mathrm{O}$ tratamento térmico secundário nessas faixas de temperatura é, assim, útil para o uso de arcos de expansão de fios superelásticos.

Klump et al. (1994) procuraram determinar a quantidade de energia disponível para movimentação dentária ortodôntica a partir da rigidez e da flexibilidade de determinado fio. 25 espécimes de 5 marcas de fios comerciais (aço inox, $\mathrm{CoCr}$, Btitânio e níquel-titânio) foram testados em tração. Os diagramas de força $x$ alongamento foram obtidos e convertidos em dados tensão $x$ deformação. Foram calculadas a relação módulo de resiliência/módulo de elasticidade $(R / E)$ e a proporção módulo de resiliência/acomodação elástica $(R / C)$. As médias do módulo de elasticidade mostraram que os fios com titânio (os autores agruparam B-titânio e níquel-titânio no mesmo grupo) tiveram valores entre 8,3 e 10,7 ×10 $\mathrm{Ibs}^{\mathrm{in}} \mathrm{in}^{2}$, (57 e 74 GPa) enquanto que os fios de aço mostraram média de $31,1 \times 10^{6} \mathrm{lbs} / \mathrm{in}^{2}$ (214 GPa) e os de Co-Cr $19,9 \times 10^{6} \mathrm{lbs} / \mathrm{in}^{2}(137 \mathrm{GPa})$ As proporções R/E R/C foram substancialmente diferentes para os três grupos, mostrando os menores valores para níquel-titânio e B-titânio, e os maiores para o aço inox. A combinação das duas proporções se mostrou eficiente para diferenciar as características dos fios das diversas ligas testadas.

A propriedade de memória única dos fios termodinâmicos é apenas parcialmente compreendida. Bishara et al. (1995) acreditam que esta resulte da capacidade inerente desses fios de alterar suas forças de atração atômica em função da temperatura. Esse fenômeno de recuperação de forma pode ser resultado de uma transição na estrutura cristalina que ocorre pela deformação e resfriamento. Quando a transição é revertida, pelo calor, a estrutura retorna à sua forma original, com a ocorrência abrupta de alterações das propriedades. A 
proposta deste estudo foi determinar as faixas de temperatura de transição (TTR) de três fios ortodônticos termodinâmicos comerciais e determinar a taxa de recuperação dos fios quando dobrados em uma determinada forma. Foi construído um dispositivo para suportar os fios e o conjunto imerso em água em um pote de acrílico. A temperatura da água foi gradualmente aumentada. Um programa foi escrito para capturar um único quadro de vídeo de um vídeo tape, permitindo ao operador cobrir a posição de cada amostra de fio. Os resultados indicaram que as TTR para os três fios comerciais foram similares em magnitude $\left(x=6,7^{\circ} \mathrm{C}, 6,2^{\circ} \mathrm{C}\right.$ e $\left.6,7^{\circ} \mathrm{C}\right)$. As maiores diferenças foram no desvio padrão $\left(1,3^{\circ} \mathrm{C} ; 2,2^{\circ} \mathrm{C}\right.$ e $\left.3,7^{\circ} \mathrm{C}\right)$ que pode ser em função da fabricação da liga ou do tratamento térmico. As ligas com memória de forma podem ser classificadas em ligas martensíticas estabilizadas, ligas martensíticas ativas e ligas austeníticas ativas. O fio nitinol estabilizado tem uma deformação predeterminada de $8 \%$ a $10 \%$. Neste trabalho, a recuperação de forma dos arcos testados foi de aproximadamente $100 \%$.

Segner e lbe (1995) desenvolveram neste estudo mecanismos para testar e comparar arcos de nivelamento cujos fabricantes alegam possuir propriedades superelásticas. Como o modelo de mola e a lei de Hook não podem ser aplicados, novos parâmetros devem ser encontrados. Pode-se demonstrar que 3 parâmetros são necessários para se descrever um arco superelástico adequadamente: a distinção do platô pseudo-elástico, a deflexão no início do platô e o nível de força no platô. Os resultados mostraram que diversos materiais ou não mostraram qualquer propriedade pseudoelástica ou que os parâmetros do fio eram tais que estes não apresentavam qualquer vantagem sobre os fios de níquettitânio trabalhados a frio (encruados). Em diversos fios, o início do platô e, conseqüentemente, as características desejáveis, começavam apenas depois do fio ter sido deslocado por 
$1 \mathrm{~mm}$ ou mais. Para diversos fios, o nível de força nesse platô também provou ser bastante alto, com valores por vezes acima de $500 \mathrm{~g}$.

O comportamento mecânico superelástico dos fios de liga ortodôntica de níquel-titânio é atribuído à transformação cristalográfica de fase austenítica para martensítica, induzida por tensão. O propósito do estudo de Thayer et al. (1995) foi comparar o comportamento superelástico de fios nitinol a alterações de fase induzidas pela tensão. Para tanto, oito arcos de níquel-titânio de secção transversa retangular $(.018 "$ x $.025 ")$ foram tracionados de $0 \%$ a $10 \%$ e analisados por meio de difração de raios-X (XRD). Os resultados indicaram que, sem deformação, os fios se mostraram predominantemente austeníticos, com alguma ocorrência de martensita. Com uma deformação de $6 \%$, os fios superelásticos mostraram transformação de fase de austenita para martensita. Os padrões de XRD foram ranqueados por percentual de transformação e largura dos picos. Os ranqueamentos dos produtos por grau de superelasticidade mostraram correlação positiva com a transformação martensítica $(p<0,05)$. O nível de superelasticidade mostrou correlação negativa com a largura dos picos de XRD $(p<0,01)$. Largura de pico aumentada indica maior grau de trabalho a frio. Vários fios encontrados no mercado apresentaram comportamento superelástico, mas o grau de trabalho mecânico a frio e o tratamento térmico são variáveis importantes a ser controladas durante a manufatura desses arcos.

Manhartsberger e Seidenbusch (1996) investigaram a liberação de forças de molas helicoidais fechadas e abertas. As abertas foram avaliadas por ensaio de compressão e as fechadas por tração. Após o primeiro ensaio, as molas foram mantidas ativadas por um período de 4 semanas e depois novamente testadas com o mesmo procedimento. Com $10 \mathrm{~mm}$ de ativação, na primeira vez a força 
correspondeu a $50 \mathrm{~g}$, que na segunda caiu para cerca de $43 \mathrm{~g}$, em mola com especificação de $50 \mathrm{~g}$, pelo fabricante. Em molas com especificações de maiores forças ocorriam casos semelhantes. Foi assim observado uma nítida diminuição na força entre a primeira e a segunda ativação.

Segundo Barwart (1996), as molas helicoidais de níquel-titânio Japonês exibem propriedades superelásticas similares às propriedades dos fios japoneses. As molas exercem força leve e contínua por uma longa faixa de ativação ou desativação. Essa propriedade permite que a mola seja usada para movimentos ortodônticos fisiológicos. Um valor constante de carga pode ser mantido somente em temperaturas constantes. Entretanto, influencias externas que afetam a boca, por exemplo a ingestão de alimentos ou bebidas, causam flutuações na temperatura que podem ser consideráveis. Neste estudo foram avaliados os efeitos das alterações de temperatura na liberação de força de molas de níquettitânio em sua faixa superelástica. Molas de níquel-titânio Japonês foram aquecidas e resfriadas entre $20^{\circ} \mathrm{C}$ e $50^{\circ} \mathrm{C}$ enquanto mantidas em extensão constante. Durante 0 procedimento, a força foi continuamente medida. Molas comerciais de aço inox foram testadas da mesma forma. Para todas as molas examinadas, os valores de carga aumentaram com o aumento da temperatura e diminuíram com a diminuição desta. Esse relacionamento entre alteração da temperatura e valor de carga foi mais claro no caso das molas de níquettitânio do que de aço inox. A força medida a $37^{\circ} \mathrm{C}$ foi cerca de duas vezes maior que a $20^{\circ} \mathrm{C}$ para um tipo de mola de níquet titânio. No aquecimento, as molas superelásticas mostraram comportamento incomum. Imediatamente após o início da diminuição da temperatura ocorreu uma rápida diminuição na força, para níveis abaixo daqueles encontrados durante 0 aumento da temperatura. Essa diminuição não linear na carga não foi observada 
nas molas de aço inox testadas. Os resultados demonstraram que pequenas alterações na temperatura podem causar alterações significantes na liberação de força das molas superelásticas de níquel-titânio.

O propósito do estudo de Bradley, Brantley e Culertson (1996) foi determinar as temperaturas de transição para as fases estruturais austenítica, martensítica e romboedral $(R)$ em arcos comerciais de níquel-titânio, para avaliar discrepâncias entre publicações recentes. Os espécimes foram examinados por calorimetria diferencial de varredura (DSC) sob uma faixa de temperatura de aproximadamente $-170^{\circ} \mathrm{C}$ a $100^{\circ} \mathrm{C}$, com uma velocidade de varredura de $10^{\circ} \mathrm{C}$ por minuto. Foram observadas duas formas de transformação da fase martensítica para a austenítica, nos fios de níquettitânio, com ou sem a estrutura $R$ intermediária, enquanto a transformação reversa de austenítica para martensítica sempre incluiu a estrutura R. A entalpia $(\Delta \mathrm{H})$ para a transformação de martensita para austenita variou de 0,3 a 3,5 calorias por grama. O menor valor de $\Delta \mathrm{H}$ para o Nitinol não superelástico é consistente com a microestrutura trabalhada a frio, estável, martensítica desse produto. Os resultados da DSC indicam que os processos de transformação são similares nos fios superelásticos termodinâmicos com memória de forma e nos fios de níquettitânio não superelásticos. Diferenças nas propriedades de dobramento nos fios de níquettitânio à temperatura ambiente e a $37^{\circ} \mathrm{C}$ são devidas às proporções relativas das fases metalúrgicas na microestrutura.

Surgimentos recentes na ciência dos materiais têm levado estes a grandes desenvolvimentos na tecnologia de arcos ortodônticos (EVANS; DURNING, 1996). O ritmo das mudanças tem sido rápido, levando o clinico a se confundir na escolha do material correto para a aplicação de força específica. O artigo identifica as propriedades de novas formulações de fios e pretende fornecer um guia para a 
escolha do material dos arcos durante os primeiros estágios da terapia ortodôntica. As fases da liberação de força podem ser divididas em 5, a saber: fase 1 - variação nas dimensões do arco, com liberação de força linear, característica dos arcos de aço inox e ouro; fase 2 - variação no material do arco, mas com a mesma dimensão - força linear - com o uso de fios de beta-titânio, níquettitânio, aço inox e Co-Cr; fase 3 - variação no diâmetro do arco (superelasticidade), com força não linear, com as características de deflexão devidas a alteração estrutural induzida por tensão fios de níquel-titânio superelásticos; fase 4 - variação na composição do material do arco, força não linear e com as características de deflexão ditadas por alteração estrutural induzida por alteração na temperatura em todo o arco - fios de níqueltitânio termoativados; fase 5 - variação na composição e estrutura do material do arco, força não linear e com as características de deflexão ditadas por diferentes alterações estruturais induzidas termicamente em secções específicas do arco.

Para Kusy (1997), o uso dos fios de memória de níquel-titânio, introduzidos na ortodontia por sua capacidade de desenvolver forças leves e contínuas, que se provaram mais eficientes que forças pesadas e intermitentes para a movimentação dentária, requer o domínio das propriedades funcionais desses fios. Mais especificamente, a força de recuperação que age sobre os dentes é uma função sensível da temperatura: o conhecimento das modificações da temperatura oral é, portanto, um requisito para o entendimento das modificações das tensões observadas durante o tratamento ortodôntico. As mudanças de temperatura na cavidade oral induzidas pela ingestão de líquidos frios ou quentes foram estudadas com o uso de arcos, fixados a aparelhos removíveis tipo Hawley, similares aos aparelhos normalmente usados para contenção ortodôntica, através de seis sensores de temperatura, localizados em posições correspondentes a dentes 
específicos. Então, um paciente usando os aparelhos bebeu entre 10 e $20 \mathrm{cl}$ de chá quente $\left(\mathrm{HT}, 60^{\circ} \mathrm{C}\right)$ ou água gelada $\left(\mathrm{CW}, 5^{\circ} \mathrm{C}\right)$, com a temperatura bucal monitorada até atingir novamente a temperatura corporal (10 a $15 \mathrm{~min}$ ). Os resultados mostram uma alteração significante da temperatura nos primeiros segundos da ingestão com posterior estabilização e lento retorno à temperatura corporal. As regiões de maiores alterações foram, no arco superior a região inter-incisal e no inferior a região dos pré-molares. Modificações na força desenvolvida pelos fios de níquettitânio são esperadas nas mesmas proporções. Segundo esse autor, os materiais utilizados pelos ortodontistas têm mudado rapidamente nos últimos anos, e continuarão mudando no futuro. Com a introdução de materiais compósitos estéticos, os fios metálicos provavelmente serão substituídos na maioria das aplicações ortodônticas, da mesma forma que as ligas metálicas têm sido substituídas por compósitos na indústria aeroespacial. Neste trabalho, os fios ortodônticos são revisados em ordem de desenvolvimento, com ênfase específica nas suas propriedades e características como resistência, rigidez, formabilidade e soldabilidade. O autor relata a história das ligas nitinol, acrônimo para Nickel Titanium Naval Ordinance Laboratory, comercializada pela Unitek com o nome de Nitinol. Ironicamente, esse composto equiatômico (50:50 Ni-Ti) era uma liga de memória apenas na composição, pois essa liga era passiva, uma vez que o efeito de memória de forma era suprimido pelo trabalho mecânico a frio pelo qual a liga passava (8 a 10\%) ao ser transformada em fio. A grande atração dessa liga martensítica estabilizada era a baixa força desenvolvida no descarregamento. Já as ligas pseudoelásticas - dois tipos genéricos de nitinol ativos - apresentam algum tipo de memória de forma, sendo, portanto, ativos: uma liga austenítica ativa e uma liga martensítica ativa. A liga austenítica apresenta as duas fases, com a martensita representando a fase de 
baixa rigidez, com módulo de elasticidade de 13 a $35 \mathrm{GPa}$. A austenita representa, assim, a fase de alta rigidez, com módulo de elasticidade de 84 a 98 GPa.

Segundo Airoldi et al. (1997), o uso dos fios de memória de níquel-titânio, introduzidos na ortodontia por sua capacidade de desenvolver forças leves e contínuas, que se provaram mais eficientes que forças pesadas e intermitentes para a movimentação dentária, requer o domínio das propriedades funcionais desses fios. Mais especificamente, a força de recuperação que age sobre os dentes é uma função sensível da temperatura: o conhecimento das modificações da temperatura oral é, portanto, um requisito para o entendimento das modificações das tensões observadas durante o tratamento ortodôntico. As mudanças de temperatura na cavidade oral induzidas pela ingestão de líquidos frios ou quentes foram estudadas com o uso de arcos, fixados a aparelhos removíveis tipo Hawley, similares aos aparelhos normalmente usados para contenção ortodôntica, através de seis sensores de temperatura, localizados em posições correspondentes a dentes específicos. Então, um paciente usando os aparelhos bebeu entre 10 a $20 \mathrm{cl}$ de chá quente $\left(\mathrm{HT}, 60^{\circ} \mathrm{C}\right)$ ou água gelada $\left(\mathrm{CW}, 5^{\circ} \mathrm{C}\right)$, com a temperatura bucal monitorada até atingir novamente a temperatura corporal (10 a $15 \mathrm{~min}$ ). Os resultados mostraram uma alteração significante da temperatura nos primeiros segundos da ingestão com posterior estabilização e lento retorno à temperatura corporal. As regiões de maiores alterações foram, no arco superior a região inter-incisal e no inferior a região dos pré-molares. Modificações na força desenvolvida pelos fios de níqueltitânio são esperadas nas mesmas proporções.

Segundo Ferreira, Mundstock e Muller (1998), no que se refere às ligas de $\mathrm{Ni}-\mathrm{Ti}$, ambos os fios .016" e .018 " podem ser usados como fios iniciais, mas mesmo dessas ligas, os fios .018" são indesejavelmente rígidos. Com o fio .016" a 
desobstrução dentro do bráquete .022", apesar de grande, não é suficiente para causar problemas clínicos. Sendo os valores de rigidez dos fios $\mathrm{Ni}$-Ti .0175" torcido e .016" de aço inox quase semelhantes, se torna de bom senso usar o fio torcido com o aparelho .022", exceto em pacientes com apinhamento mais severo, onde a amplitude e esforço maiores do $\mathrm{Ni}$-Ti são úteis. O fio .016" de níquel-titânio tem propriedades excepcionais de elasticidade e amplitude, porém as ligas marte nsíticas originais possuem muito pouca formabilidade. Os fios de ligas superelásticas, ao serem ativados, provocam um rápido aumento na carga inicialmente, que retorna a um nível constante sobre uma longa extensão, apesar do aumento de ativação. Assim, os fios de $\mathrm{Ni}-\mathrm{Ti}$ podem ser plasticamente deformados em sua fase martensítica. Quando aquecidos, para temperaturas acima da temperatura de transição $\left(A_{f}\right)$, a estrutura do cristal muda para a fase austenítica e o fio retorna à forma prevista em que foi fabricado.

Para Meling e Odegaard (1998a) as ligas de memória de forma podem ser deformadas plasticamente em sua fase martensítica, mas retornarão à fase austenítica, recuperando, assim, sua forma original, se aquecidas acima de certa faixa de temperatura. A forma original do arco é dada "memorizada" com a liga em fase austenítica ou fase mãe, durante o tratamento térmico. Em um arco termoativado, dobras podem ser feitas em um estado martensítico altamente dúctil à temperatura ambiente, para permitir um perfeito acoplamento do fio aos bráquetes em dentes severamente mal posicionados. Com o aquecimento subseqüente à instalação do arco na boca, o fio tentará retornar à sua forma original, exercendo força nos dentes. Entretanto, para ser clinicamente relevante, a temperatura de transição deve ser um pouco abaixo ou bem próxima à temperatura bucal. Em uma liga com memória de forma (superelasticidade), a transformação da fase austenítica 
para martensítica também pode ocorrer pela aplicação de tensões em determinada faixa de temperatura. A fase martensítica formada por esse processo é chamada Martensita Induzida por Tensão (SIM), e a energia usada para a transformação é mecânica, e não térmica. Em determinada faixa de temperatura, a martensita pode se tornar estável com a aplicação de tensão, porém se torna novamente instável quando a tensão é removida. Há uma relação linear entre tensão e temperatura para a indução martensítica, uma diminuição na temperatura é equivalente a um aumento na tensão. O objetivo deste trabalho foi avaliar os efeitos da temperatura, na resposta elástica de fios superelásticos de níquettitânio, à torção longitudinal quando testados em uma situação simulando a aplicação de torque em um dente. Para isso, fios retangulares de cobre-níquel-titânio normalmente usados na técnica edgewise .018" foram testados nas condições em que foram recebidos. Seis fabricantes, quatro dos maiores fabricantes dos EUA e dois da Alemanha, forneceram um total de oito tamanhos e tipos de arcos diferentes, todos com alegadas propriedades superelásticas. De cada grupo foram cortados segmentos de $25 \mathrm{~mm}$ da porção posterior dos arcos, que é quase reta. Esses segmentos foram testados em um instrumento de medição de torque com uma distância interbráquetes de $4 \mathrm{~mm}$. Os corpos de prova foram ligados a três bráquetes com amarrilhos elásticos e ativados em $25^{\circ}$ de torção longitudinal e depois desativados até zero. Os resultados permitiram concluir que a maioria dos fios teve platôs de desativação estreitos, a altos níveis de ativação e apenas um teve um platô largo com ângulo de ativação abaixo do pré-torque recomendado pelas prescrições de bráquetes comuns. Os fios com pequena ou sem pseudo-elasticidade demonstraram platôs de desativação apreciáveis quando ativados de 45 a $60^{\circ}$. Esses resultados suportam a hipótese de que essas ligas têm propriedades superelásticas, porém a 
ativação de $25^{\circ}$ foi insuficiente para induzir a transformação martensítica. Os fios foram flexíveis à temperatura ambiente e se tornaram mais rígidos com o aumento da temperatura. Metade dos fios foram marcadamente influenciados pelas alterações na temperatura, enquanto a outra metade foi relativamente insensível a essas alterações. A sensibilidade térmica de um fio parece estar intimamente relacionada às suas tendências superelásticas.

Meling e Odegaard (1998b) estudaram vinte e cinco arcos de níqueltitânio superelásticos ou convencionais, comumente usados na técnica edgewise .018", fabricados por 7 empresas, além de um fio trançado de níquel-titânio e dois fios de beta-titânio, onde se analisaram as dimensões, biselamento e propriedades mecânicas em torção longitudinal a $37^{\circ} \mathrm{C}$. Os fios foram girados $25^{\circ}$ e estudados na desativação, simulando a aplicação de torque em um dente individual. Como suporte foram usados bráquetes standard com slot .018" declarados e .0187" medidos. A maioria dos fios variaram \pm 0.0005 " das dimensões declaradas pelos fabricantes, porém mostraram mais biselamento que previamente reportado para fios de aço inoxidável e cromo-cobalto. Variações nas dimensões dos fios e no bisel levam a liberação de forças de torção (terceira ordem) variáveis. A resistência à torção variou entre os fabricantes com as várias dimensões dos fios, sendo resultado das diferenças na real geometria transversal dos fios e das propriedades dos materiais. Nenhuma das amostras testadas exibiu propriedades superelásticas sob as condições do teste e apenas um dos fios teve uma tendência superelástica.

A força de recuperação dependente da temperatura, característica das ligas de níquel-titânio foi avaliada por Fukuizumi, Kakigawa e Kozono (1999) em um fio de memória contendo cobre com ponto $A$ (fase austenítica final) nominal de $40^{\circ} \mathrm{C}$, um fio de Ni-Ti superelástico (SE) e um fio de aço inox 18-8 (SS), das mesmas 
dimensões (retangular, .016" x .022”). As características dos fios foram analisadas por DSC e testes de dobramento. O fio de memória (SM) escoava em 0,25 mm de deflexão com força de $65 \mathrm{gf}$, atingindo $2 \mathrm{~mm}$ de deflexão sem aumento significante da força. Forças maiores foram geradas quando o fio foi aquecido acima da temperatura $A_{f}: 40,50$ ou $60^{\circ} \mathrm{C}$. Com o resfriamento da liga abaixo do ponto $A_{f}$, a força diminuiu novamente, e vice-versa. Além disso, a baixas temperaturas, $\left(23^{\circ} \mathrm{C}\right)$, apenas um quarto da deflexão imprimida foi recuperada elasticamente, demonstrando que as características mecânicas dessa liga dependem grandemente da temperatura. A excelente reversibilidade, reprodutibilidade e durabilidade da força de recuperação também foram confirmadas. Esses resultados indicam que os fios de memória podem ser um material razoável para um novo conceito de tratamento ortodôntico intermitente, em que forças suaves são aplicadas aos dentes na maioria das horas do dia e o movimento dos dentes será intermitentemente acelerado por forças maiores geradas apenas quando o paciente ingere bebidas ou alimentos quentes.

Kawashima, Ohno e Sachdeva (1999) fizeram testes simples de dobramento em três pontos em fios de níquel-titânio com três diferentes pontos $A_{f}$ $\left(1^{\circ} \mathrm{C}, 13^{\circ} \mathrm{C}\right.$ e $\left.34^{\circ} \mathrm{C}\right)$ para esclarecer o relacionamento entre a temperatura $A_{f}$ e as alterações de carga sob deformação constante. Cada fio foi deformado a $37^{\circ} \mathrm{C}$ e então foram impostas variações térmicas a temperaturas de $2^{\circ} \mathrm{C}$ ou $60^{\circ} \mathrm{C}$. As alterações de carga com as alterações térmicas de 37 para $2^{\circ} \mathrm{C}$ ou $60^{\circ} \mathrm{C}$ mostraram a mesma tendência em fios com diferentes pontos $A_{f}$ : no estagio de carregamento, a força tornou-se menor que o nível inicial a $37^{\circ} \mathrm{C}$ e no estagio de descarregamento a força se tornou menor que a inicial. A maior alteração de força no estagio de carregamento foi medido no fio com ponto $A$ de $13^{\circ} \mathrm{C}$. Deve-se ter cuidado ao 
manipular fios de níquettitânio com ponto $A_{f}$ menor que $1^{\circ} \mathrm{C}$, a fim de prevenir que 0 fio alcance o limite crítico de tensão de deformação plástica, quando a temperatura da boca sobe a mais de $40^{\circ} \mathrm{C}$.

Barwart, Rollinger e Burger (1999) usaram o método de calorimetria diferencial de varredura (DSC) para se determinar as faixas de temperaturas de transição (TTR) de 4 tipos de molas ortodônticas de Ni-Ti (Sentalloy). O conhecimento das faixas de temperatura de transição fornece informação sobre a temperatura em que o fio ou mola de $\mathrm{Ni}-\mathrm{Ti}$ pode assumir as propriedades superelásticas e quando essa qualidade desaparece. Os tipos de mola neste estudo podem ser distinguidos um do outro por sua TTR característica durante o resfriamento ou aquecimento. Para cada tipo de mola testado, foi avaliado um TTR durante o aquecimento (transformação austenítica) ou resfriamento (transformação martensítica). A histerese da temperatura de transição, entre o resfriamento e o aquecimento, foi de 3,4 a 5,2 K. Dependendo do tipo de mola, a temperatura inicial da transformação austenítica $\left(A_{s}\right)$ ficou entre 29,2 e $37^{\circ} \mathrm{C}$. A temperatura inicial da transformação martensítica $\left(M_{s}\right)$ ficou entre 32,6 e $25,4^{\circ} \mathrm{C}$, enquanto a $M_{f}$ (temperatura final da transformação martensítica) foi de 12,7 a $6,5^{\circ} \mathrm{C}$. Os resultados mostraram que as molas se tornam superelásticas quando a temperatura aumenta e alcança $A_{s}$. Elas passam por uma perda das propriedades superelásticas e uma rápida diminuição na força desenvolvida quando resfriadas até M. Para as molas testadas, $A_{f}$ e $M_{f}$ ficaram abaixo da temperatura ambiente. Assim, à temperatura ambiente e alguns graus abaixo, todas as molas exerceram propriedades superelásticas. Para o tratamento ortodôntico isso significa a manutenção do comportamento superelástico, mesmo quando a temperatura bucal desce para 
próxima à temperatura ambiente, como pode ocorrer, por exemplo, durante as refeições.

O objetivo do trabalho de Baldwin, Pender e Last (1999) foi determinar os efeitos in vivo, do movimento dentário com fios de níqueltitânio, no periodonto durante os estágios iniciais do tratamento ortodôntico. Foram medidos a extensão do movimento, a severidade da inflamação gengival, a profundidade de bolsa, o fluxo de fluido crevicular e a quantidade de dois componentes desse fluido: sulfato de condroitina (CS) e glicosaminoglicano (GAG), em um canino superior de cada um dos 33 pacientes tratados com aparelhos pré ajustados. Foram feitas medições antes e durante 4 estágios das primeiras 22 semanas do tratamento. Os resultados mostraram que o fluxo do fluido crevicular aumentou após 4 semanas de movimento dentário, enquanto o aumento de CS, que indica metabolismo tissular periodontal, ocorreu no estágio final da $10^{\mathrm{a}}$ semana. Os dentes que mostraram as maiores quantidades de movimento continuaram a exprimir grandes quantidades de CS em grandes volumes de fluido até a $22^{\underline{a}}$ semana, enquanto os níveis de CS nos dentes com menor movimento diminuíram. Esses dados sugerem que os fios de níquet titânio podem produzir efeito de platô superelástico in vivo em dentes, que apresentam grandes movimentações nas primeiras 22 semanas de tratamento.

Nakano et al. (1999) procuraram esclarecer as propriedades mecânicas de 42 marcas de fios ortodônticos de níquettitânio de 9 fabricantes com testes de dobramento em 3 pontos sob condições uniformes. Os fabricantes foram ACompany, Hoya Medical, Lancer, Ormco, Rocky Mountain, Sankin, Tomy (GAC), TP, e 3M/Unitek. Fios de Co-Cr e TMA também foram testados como referência para comparação dos níveis de força. Todos os dados foram registrados durante o processo de descarregamento, para simular a força que o fio exerce no dente 
durante seu movimento no arco dental. Os seguintes resultados foram obtidos dos fios de níqueltitânio testados: (1) Entre os fios redondos .016 " testados sob deflexão máxima de $1,5 \mathrm{~mm}$, a diferença entre o menor (Copper Ni-Ti 35) e o maior (Aline) valor de carga foi de $136 \mathrm{~g}$. Para os fios retangulares $.016 \times .022 "$, a diferença entre o menor valor de carga (Copper Ni-Ti 40) e o maior (Aline) foi de 337g. (2) A alteração da carga entre 1,5 e 0,5 mm de deflexão foi examinada para esclarecer a propriedades superelásticas dos fios testados. Para os fios redondos $.016 ", 17$ marcas produziram uma diferença de carga de menos de $100 \mathrm{~g}$, e duas marcas produziram uma diferença de pelo menos $100 \mathrm{~g}$ (Aline e Titanal) Para os fios .016 "x .022 ", 15 marcas produziram diferença de menos de $100 \mathrm{~g}$ e oito de pelo menos 100g. A maior e a menor diferença foram de $3 \mathrm{~g}$ (Copper $\mathrm{Ni}-\mathrm{Ti} 35)$ e de $200 \mathrm{~g}$ (Aline). (3) A maioria das amostras com as menores diferenças entre deflexões de 1,5 mm e $0,5 \mathrm{~mm}$ no processo de descarga estavam entre os fios superelásticos, enquanto as maiores diferenças se encontraram predominantemente entre os fios trabalhados a frio. Comparados com os fios de Co-Cr e TMA, os fios de níquettitânio exerceram forças significantemente menores. Entretanto, a quantidade de força variou muito de marca para marca. Conseqüentemente, a marca do fio de níquettitânio deve ser cuidadosamente selecionada, levando-se em consideração a severidade da máoclusão e o estágio do tratamento ortodôntico em cada caso. É intenção deste estudo oferecer ao clínico um guia imparcial para a seleção do fio de níquel-titânio apropriado.

Thayer, Fox e Meyer (1999) apresentaram um novo tipo de liga, Nitinol Total Control (NTC), e comparam suas propriedades com ligas de TMA, TiNB, níqueltitânio superelástico e aço inox, usando arcos comerciais .016" x .022" em testes de fricção, dobramento em três pontos e dobrabilidade. Nos testes de fricção, 
as maiores forças foram mostradas pelo fio TiNB, seguido pelo TMA, NTC, SE NiTi e o menor pelo aço inox. Já nos testes de dobramento, as maiores forças foram desenvolvidas pelos fios de aço inox, que também mostrou a maior deformação permanente, sendo que os fios NTC e SE Ni-Ti mostraram as menores forças sem deformação permanente. Esses resultados demonstraram que o novo produto alia a superelasticidade do níquettitânio com a dobrabilidade das ligas tradicionais, sem dependência de temperatura.

Minervino et al. (2000), após uma revisão bibliográfica chegaram a uma série de conclusões em relação aos fios de memória de forma. Segundo os autores, apresentam duas propriedades fundamentais: memória de forma e superelasticidade. Clinicamente, essas características resultam em alinhamento e nivelamento mais eficazes, com menor tempo de cadeira do paciente e menos desconforto (menos dor). Quando utilizados fios retangulares no início do tratamento já pode ser esperado um controle de torque dos dentes, tornando a mecânica mais eficiente. Essas ligas de memória facilitam o tratamento ortodôntico pela dissipação de forças leves e constantes, necessária à movimentação dentária mais fisiológica.

Melling e Odegaard (2001) argumentaram que a resistência ao dobramento dos fios superelásticos de níquel-titânio é influenciada pelas alterações na temperatura bucal. As fases de ativação e desativação de um gráfico de cargadeflexão de um fio superelástico têm diferentes magnitudes de tensão. Esta investigação comparou o efeito do resfriamento e do aquecimento rápidos na força de dobramento exercida por arcos de níquel-titânio. Dois arcos retangulares superelásticos e um convencional de níquettitânio foram testados em dobramento a $37^{\circ} \mathrm{C}$. Os espécimes foram testados durante as fases de ativação e desativação. 
Os arcos foram mantidos sob deformação constante e a força de dobramento medida continuamente, enquanto os espécimes ativados eram submetidos a água fria $\left(10^{\circ} \mathrm{C}\right)$ ou quente $\left(80^{\circ} \mathrm{C}\right)$. As situações de teste simulam um arco instalado na boca de um paciente que é submetido a variações de temperatura por ingestão de alimentos ou bebidas, quentes ou frios, durante uma refeição. O fio de níquel-titânio convencional foi muito pouco afetado pelas alterações rápidas de temperatura, qualquer que fosse a fase de ativação. Em contraste, os fios superelásticos foram fortemente afetados pela aplicação rápida de água quente ou fria. Quando testados na fase de ativação, o efeito do aquecimento foi transitório, com o fio exercendo força abaixo da inicial durante a aplicação de água fria por curto período. Quando testado na fase de desativação, o efeito também foi transitório, com o fio exercendo força acima da inicial após aplicação de água quente por curto período. O efeito de alterações rápidas na temperatura sobre a rigidez dos fios de níquel-titânio superelásticos depende da fase de dobramento. O resfriamento induz a efeitos transitórios em um fio na fase de desativação, porém esses efeitos são prolongados quando o fio é testado na fase de ativação. Em contraste, os efeitos do aquecimento rápido são transitórios quando o fio é testado na fase de ativação, porém prolongados na fase de desativação.

Muraviev, Ospanova e Shlyakhova (2001) propuseram um método para estimar as forças produzidas por arcos de níquel-titânio superelásticos sob grandes deflexões. O método é baseado nas seguintes hipóteses: (1) a transição da deformação elástica para o platô martensítico ocorre a certa quantidade de deflexão e (2) a força no platô não depende da deflexão. Essas constatações são ambas aproximadas, de forma que o método é aproximado. Os principais parâmetros do método são o módulo de elasticidade e a deformação critica que induz a 
transformação martensítica. Esses parâmetros para os fios de níquettitânio podem ser determinados em uma curva de dobramento experimental de um fio feito dessa liga. Após a determinação desses parâmetros, podem-se estimar as forças que agem sobre os dentes em qualquer fio redondo ou retangular dessa liga, em qualquer distância entre dentes. Devido ao efeito da superelasticidade, a relação da força com a secção transversal e a distância entre dentes em grandes deflexões é diferente daquela das deformações elásticas. O método proposto pode ser aplicado a fios de qualquer liga superelástica de níquettitânio. Para se determinar o módulo de elasticidade e a deformação crítica da liga, pode-se usar uma curva de dobramento experimental para o fio. Notourse que os resultados de dobramento em 2 pontos ou com geometria de engastamento também são apropriados para esse fim. Nesses casos, podem-se obter equações similares às usadas no método proposto.

Segundo Santoro, Nicolay e Cangialosi (2001b), dois fenômenos concomitantes são responsáveis pelo comportamento superelástico dos fios ortodônticos de níquettitânio: uma transformação de fase relacionada à temperatura (TTR) em determinada faixa de temperatura transicional (termoelasticidade) e a formação de fase martensítica induzida por tensão (SIM - Stress Induced Martensite) em áreas localizadas do arco devido à deflexão (pseudoelasticidade). O efeito de memória de forma é derivado da transformação termoelástica de martensita para austenita e as aplicações clínicas exigem que a TTR esteja localizada pouco abaixo da temperatura oral. Esse tipo de liga termoelástica, entretanto, será completamente austenítica à temperatura oral e essa fase apresenta alto módulo de elasticidade, o que resulta em rigidez aumentada do fio. Em ligas austeníticas, a formação de SIM garante a presença do comportamento superelástico necessário 
para a liberação de forças leves e continuas. Conseqüentemente, a temperatura final da fase austenítica $\left(A_{f}\right)$ não pode ser muito abaixo da temperatura bucal ou a SIM não ocorrerá. Na verdade, recomenda-se a avaliação da liga com base na temperatura de transição relacionada à tensão, pois a aplicação de tensão normalmente aumenta a $A_{f}$ da liga. De acordo com os dados disponíveis na literatura, a maioria dos fios superelásticos disponíveis comercialmente exibem $A_{f}$ relacionada à tensão na faixa de $22^{\circ} \mathrm{C}$ a $28^{\circ} \mathrm{C}$, e a TTR dos fios termoelásticos fica situada em temperaturas mais altas, de $35^{\circ} \mathrm{C}$ a $40^{\circ} \mathrm{C}$. Em resumo, duas propriedades fundamentais devem ser levadas em consideração para se fazer uma seleção racional de um fio de níqueltitânio: uma TTR relacionada à tensão apropriada, correspondente a uma temperatura pouco abaixo da temperatura oral, e liberação de força de desativação leve sobre a estrutura dento-alveolar, para prevenir efeitos colaterais deletérios, como dor após hialinização do ligamento periodontal e possível reabsorção radicular.

Neste outro trabalho, Santoro, Nicolay e Cangialosi (2001a) abordaram as características mecânicas para a liberação de um nível fisiológico de forças. Esta liberação é relacionada à presença da martensita na liga e é, portanto dependente da TTR, bem como da quantidade de tensão induzida. O tipo de aplicação de carga nos ensaios deve reproduzir de forma o mais próximo possível situações clínicas. Consideram que o modelo de dobramento de três bráquetes representa um design consistente. Para avaliar a superelasticidade deve ocorrer no mínimo uma deflexão de $2 \mathrm{~mm}$ para formar SIM em fios austeníticos. Uma deflexão menor que $2 \mathrm{~mm}$ se traduzirá em liberação de maior força devido à fase austenítica mais rígida. Em dentes com comprometimento periodontal, cada dente na região incisal inferior não deverá suportar mais de 100g. Mas dados mostram que um fio Ni-Ti .016" x .022" 
superelástico austenítico disponibiliza de 200 a $300 \mathrm{~g}$. No entanto fios com as mesmas dimensões mas termoativados entre 35 e $40^{\circ} \mathrm{C}$ fornece forças em torno de $100 \mathrm{~g}$.

Gurgel et al. (2001c) avaliaram os momentos de torção na ativação e desativação de fios comerciais de níquel-titânio indicados para uso nas fases iniciais do tratamento ortodôntico. Nove fios de níquel-titânio retangulares (.017" x .025”) foram testados em torção. Um fio era de níquel-titânio convencional e os outros superelásticos. Os espécimes foram testados em um torquímetro para rotações entre 10 e 40 graus na ativação e na desativação. Os fios E27, Rf e R tiveram os maiores momentos, sem evidência do platô típico do efeito superelástico. Platôs de momentos constantes foram observados nos fios C27, C35, E35, MO, NS e NI. Os momentos de torção variaram entre os fios superelásticos, mesmo entre fios com a mesma faixa de temperatura de transição.

Gurgel et al. (2001b) compararam, neste estudo in vitro, o comportamento de força-deflexão de 8 fios ortodônticos superelásticos de níquel-titânio (.017" x .025 ”) sob momento e temperatura controlados. Para simular o nivelamento de um incisivo lateral, foram usados bráquetes e tubos de molares sem torque ou angulação. Os fios $(n=5)$ foram amarrados a esses bráquetes de aço inox colados a um dispositivo plástico que simulava o arco mandibular, com distância interbráquetes de $5 \mathrm{~mm}$, escolhida arbitrariamente como distância inter-bráquetes clínica média. Uma máquina de testes Instron aplicou deflexões de 0,2 a $2,0 \mathrm{~mm}$ a $35^{\circ} \mathrm{C}$ na área do incisivo lateral. Os diagramas de força-deflexão foram determinados a partir da posição passiva até uma ativação de $2,0 \mathrm{~mm}$ e durante a desativação. As forças na desativação a uma deflexão de $1 \mathrm{~mm}$ foram comparadas por análise de variância. Foram observadas diferenças significantes $(P<0,05)$ nas forças entre os fios. As 
menores forças de desativação foram dos fios Elastinol 35 (Masel) e Morelli (SP, Brasil), com médias de 190gf, enquanto as maiores foram do fio Rematitan Lite (Dentaurum, Ge), com média de 834gf. Todos os fios exibiram comportamento superelástico, em níveis de carga estratificados.

Hemingway et al. (2001) idealizaram um manequim para realizar testes sobre a influência do tipo de bráquete sobre as forças exercidas por fios de níquet titânio, em um ambiente de simulação clínica. Para isso usaram 4 tipos de bráquetes e testaram os fios em 4 pontos diferentes do manequim, que representavam as localizações do incisivo lateral, canino, segundo pré-molar e primeiro molar. Os resultados mostraram que as forças de pico e do platô dependem de uma série de fatores, com $20 \%$ dos arcos do mesmo tipo e fabricante, desenvolvendo forças de pico mais altas. Houve diferenças significantes entre os 4 tipos de bráquetes testados para a força máxima, mas essas diferenças foram muito pequenas para as forças de descarga. Argumentaram que os fios desenvolveram forças previsíveis nas curvas de descarregamento, mas os bráquetes auto-fechantes podem não permitir deslocamento suficiente para provocar tensão no arco que aproveite completamente os efeitos dos fios de níquel-titânio.

A proposta do estudo de lijima et al. (2002b) foi investigar as propriedades mecânicas de fios ortodônticos de níquel-titânio sob condições controladas de tensão e temperatura. Três fios superelásticos de níquel-titânio (Ormco Ni-Ti e Ti-NiCu-Cr e GAC Sentalloy, todos nas dimensões nominais de .016" x .022") foram examinados usando calorimetria diferencial de varredura (DSC) e micro difração de raio $X$ (micro-XRD). Os testes de dobramento em três pontos (distância interbráquetes de $14 \mathrm{~mm})$ foram feitos em temperatura constante $\left(23,37\right.$ e $\left.60^{\circ} \mathrm{C}\right)$ e com alterações graduais de temperatura $\left(37^{-60^{\circ}} \mathrm{C}\right.$ e para $\left.37^{\circ} \mathrm{C}\right)\left(37^{-} 2^{\circ} \mathrm{C}\right.$ e para $\left.37^{\circ} \mathrm{C}\right)$. 
Cinco espécimes de cada fio foram testados. O espectro do micro-XRD foi medido no lado de tensão dos fios quando a temperatura mudava de 37 para 60 ou $2^{\circ} \mathrm{C}$. A carga durante as alterações graduais de temperatura foi consistente com as medidas a temperaturas constantes. O espectro do micro XRD mostrou claramente que a fase austenítica foi transformada em martensítica quando a temperatura diminuiu de 37 para $2^{\circ} \mathrm{C}$. Na alteração de 37 para 60 e para $37^{\circ} \mathrm{C}$, a carga se tornou maior que a carga original a cada temperatura constante correspondente. Entretanto, não houve alteração detectável no espectro micro XRD quando a temperatura aumentou de 37 para $60^{\circ} \mathrm{C}$. Os fios superelásticos de níquettitânio exibiram propriedades mecânicas complicadas e inesperadas sob alteração gradual de temperatura. Este estudo mostra a possibilidade de análise qualitativa usando o micro XRD para se compreender as propriedades mecânicas desses fios de níquel-titânio.

lijima et al. (2002a) estudaram os comportamentos de transformação de fase de três arcos comerciais de níquel-titânio com diferentes temperaturas de transformação com micro-difração de raios-X (micro-XRD). O espectro foi obtido a partir de 3 diferentes ângulos de dobramento $\left(135^{\circ}, 146^{\circ}\right.$ e $\left.157^{\circ}\right)$ e temperaturas $\left(25^{\circ} \mathrm{C}, 37^{\circ} \mathrm{C}\right.$ e $\left.60^{\circ} \mathrm{C}\right)$. A proporção da intensidade (M002/A110) entre o pico 002 do $\mathrm{Ni}-\mathrm{Ti}$ martensítico e o pico 110 do austenítico foi usada como índice para as quantidades de fase austenítica e martensítica. A proporção de fase martensítica aumentou em todos os fios com a diminuição do ângulo de dobramento (maior deformação permanente), e foi menor na área de compressão do que na área de tração, para todos os fios e ângulos de dobramento. O exame de micro-XRD provou-se um método efetivo para a avaliação quantitativa das proporções dos fios bifásicos de níquettitânio, mesmo que existam orientações cristalográficas preferenciais devido ao processo de trefilação do fio. 
Brantley, lijima e Grentzer (2003) referiram-se ao método DSC (differntial scanning calorimetry -calorimetria diferencial de varredura) como um bem conhecido método de investigação de transformação de fases em fios ortodônticos de níquet titânio. Como o estudo das fases microestruturais e suas transformações são de grande importância clínica, propuseram empregar a recente desenvolvida técnica DSC modulada por temperatura (TMDSC - temperature-modulated differntial scanning calorimetry). Avaliaram 3 fios ortodônticos de níqueltitânio (Neo Sentalloy, $35^{\circ} \mathrm{C}$ Cobre Ni-Ti e Nitinol SE). No meio bucal, os 2 primeiros são fios superelásticos e apresentam memória de forma e o terceiro apresenta comportamento superelástico, mas não memória de forma. Conduziram os ensaios entre -125 e $100^{\circ} \mathrm{C}$. Dos resultados, os autores chegaram a algumas conclusões. O método TMDSC mostra que os processos de transformação de fases em fios ortodônticos de $\mathrm{Ni}$-Ti são bem mais complexos que as transformações observadas com o método DSC. Enquanto o método convencional DSC sugeriu, que no fio Neo Sentalloy, a transformação ocorre entre Ni-Ti martensítico e austenítico, no TMDSC verificourse que em aquecimento há uma transformação inicial de martensita $\mathrm{Ni}-\mathrm{Ti}$ em fase R (fase romboédrica), seguida por transformação da fase $\mathrm{R}$ em austenita $\mathrm{Ni}$ Ti. A seqüência reversa ocorre das 2 transformações parece ocorrer durante o resfriamento. Com os outros fios, o comportamento é um pouco diverso. Em alguns casos, o dobramento do fio em $135^{\circ}$, os picos martensíticos em baixa temperatura são maiores. Sugeriram que futuros estudos de transformação de fases devem ser realizados com o método TMDSC para melhor conhecimento da complexa transformação de fases na estrutura dos fios de níquel-titânio.

Yanuru et al. (2003) observaram as forças ortodônticas dos fios de níqueltitânio amarrados aos arcos dentais, com variações na temperatura e deflexão. Os 
espécimes testados foram um fio superelástico comercial (W1) e dois fios de memória com ponto $A_{f}$ nominal de $35^{\circ} \mathrm{C}(\mathrm{W} 2)$ e $40^{\circ} \mathrm{C}(\mathrm{W} 3)$, respectivamente. Estes mostraram curvas superelásticas típicas, com histerese quando amarrados, a $40^{\circ} \mathrm{C}$. Os níveis de força foram significantemente maiores que aqueles geralmente obtidos em testes de dobramento em 3 pontos. As forças de recuperação na região do platô com $1 \mathrm{~mm}$ de ativação foram bem maiores do que as indicadas clinicamente, à temperatura bucal. No fio de memória $W 3$, a força de recuperação diminuiu rapidamente até zero, com pequena redução da deflexão a partir do máximo. Entretanto, o fio voltou a exercer força com a deflexão permanente remanescente pelo aumento da temperatura. Esta foi comparável às forças clinicamente desejáveis e parecem ser úteis, especialmente em pacientes hipersensíveis.

Já Parvizi e Rock (2003) investigaram as características de cargadeflexão de três fios ortodônticos de níquel-titânio termoativos usando um arco comum de níquettitânio como controle. Fios redondos de $0,4 \mathrm{~mm}$ e retangulares de $0,4 \times 0,56 \mathrm{~mm}$ foram submetidos a 2 e $4 \mathrm{~mm}$ de deflexão submersos em água a temperaturas de 20,30 e $40^{\circ} \mathrm{C}$. As forças foram medidas em dobramento em três pontos e em manequim. As análises demonstram que, a despeito do tipo de teste e fio, as dimensões do arco tiveram efeito significante $(P<0,001)$ nas forças produzidas. Um aumento da dimensão do fio do $0,4 \mathrm{~mm}$ redondo para o $0,4 \times 0,56$ $\mathrm{mm}$ retangular quase dobrou os valores de força para a mesma deflexão. $\mathrm{O}$ efeito da deflexão nos valores de força variou de acordo com o sistema de teste, sendo as forças muito mais altas no manequim do que nos testes de dobramento simples. Nestes últimos, um aumento na deflexão de 2 para $4 \mathrm{~mm}$ não teve efeito significante nas forças exercidas, mas no manequim as forças produzidas por cada arco com deflexão de $4 \mathrm{~mm}$ foram quatro ou cinco vezes maiores que as produzidas com 
deflexão de $2 \mathrm{~mm}$. Todos os fios termoativos produziram menores forças que os fios comuns. Entretanto, houve grande variação entre os três tipos de fios termoativos. Nos testes de dobramento, cada $10^{\circ} \mathrm{C}$ de aumento na temperatura de 20 para $40^{\circ} \mathrm{C}$ teve efeito significante na força produzida $(P<0,001)$. No manequim houve aumento de força significante entre os $20^{\circ} \mathrm{C}$ e os $30^{\circ} \mathrm{C}(\mathrm{P}<0,001)$, mas entre os $30^{\circ} \mathrm{C}$ e os $40^{\circ} \mathrm{C}$ as forças não aumentaram significantemente.

Fischer-Brandies et al. (2003) utilizaram cinco fios ortodônticos comerciais de níquel-titânio nas dimensões .016" x .022" (Neo Sentalloy F80, Thermo-Active Copper NiTi 35ㄷ, Rematitan "Lite", Titanol SE S e Titanal) para estudar seus comportamentos de transformação, composição química, topografia superficial e propriedades mecânicas nas temperaturas de 22,37 e $60^{\circ} \mathrm{C}$. A composição química e topografia superficial foram analisadas por espectroscopia dispersiva de raios- $x$ utilizando um microscópio eletrônico de varredura analítico. As temperaturas de transição foram medidas por DSC em uma faixa de $-80^{\circ} \mathrm{C}$ a $+80^{\circ} \mathrm{C}$. As propriedades mecânicas e sua dependência da temperatura foram determinadas por testes de dobramento em 3 pontos. Os materiais binários dos arcos foram caracterizados por uma estrutura de duas fases (uma matriz de $\mathrm{Ni}$-Ti e precipitados de $\mathrm{Ni}_{3} \mathrm{Ti}_{4}$ ). A análise do MEV revelou resíduos abrasivos, enquanto que o exame DSC revelou propriedades de transformação complexas. Além disso, foi detectada a ocorrência de fase $R$ nas transformações austeníticas e martensíticas. Os testes de dobramento mostraram platôs pronunciados tanto no carregamento como no descarregamento. Os arcos martensíticos (Neo Sentalloy F80 e Thermo-Active Copper $\mathrm{NiTi} 35^{\circ} \mathrm{C}$ ) apresentaram menor resistência que os arcos austeníticomartensítico (Rematitan "Lite") e austeníticos (Titanol SE S e Titanal). Com o aumento da temperatura (na faixa de 22 a $60^{\circ} \mathrm{C}$ ), foi registrado um aumento linear 
nas forças dos platôs. Assim, ao analisar a qualidade dos arcos de níquettitânio, deve-se levar em conta a qualidade superficial, uma vez que esta determina a resistência à corrosão, características de biocompatibilidade e fricção. As propriedades mecânicas dependem do estado inicial; forças moderadas no platô e os momentos do platô só podem ser observados em arcos martensíticos. Ao contrário dos arcos convencionais de aço inox, as características de resistência são fortemente dependentes da temperatura e devem ser conhecidas para se obter o melhor efeito dos arcos de níquettitânio. Finalmente, a propriedade de superelasticidade é apenas parcialmente utilizada, se muito, quando a necessidade de nivelamento é mínima.

A fim de determinar se a temperatura de transição de arcos de $\mathrm{Cu}-\mathrm{Ni}-\mathrm{Ti}$ influencia na quantidade de movimentação dentária, Dalstra e Melsen (2004) instalaram aparelhos ortodônticos em 50 pacientes com níveis idênticos de desalinhamentos dentários. Os pacientes foram tratados com arcos de $\mathrm{Cu}-\mathrm{Ni}-\mathrm{Ti}$ divididos em duas metades, uma com temperatura de transição de $27^{\circ} \mathrm{C}$ e outra com $40^{\circ} \mathrm{C}$, unidas na região central. $\mathrm{O}$ movimento dentário, expresso em duas translações e uma rotação no plano oclusal, foi medido em fotografias intra-orais tomadas logo após a instalação dos aparelhos e um mês depois. O movimento dentário foi maior no lado de $40^{\circ} \mathrm{C}$, apesar de que essa tendência só foi estatisticamente significante em casos de translação total dos pré-molares. No geral, os pacientes não notaram diferenças entre os dois lados dos arcos, apesar de que uma paciente considerou o lado de $27^{\circ} \mathrm{C}$ mais confortável, uma vez que o lado de $40^{\circ} \mathrm{C}$ a incomodava quando ela bebia algo quente. Assim, os resultados demonstram que a temperatura de transição dos arcos de Cu-Ni-Ti tem influência 
sobre a quantidade de movimentação dentária conseguida, apesar de que a diferença é tão pequena que, na prática, inexiste.

A fim de determinar a resistência ao dobramento de fios superelásticos em função das dimensões transversais dos fios, Garrec e Jordan (2004) selecionaram 15 espécimens de uma liga ortodôntica de níquel-titânio (Thermo NITI, Ortho-Force, Paris, France) em 3 secções transversais diferentes (.016" x .016", $.018 " \times .018 "$ e $.020 " x .020 ")$. Os testes de dobramento em 3 pontos foram realizados em segmentos de $14 \mathrm{~mm}$, em máquina GT (GT-Test Gmbh Universal testing machine, model 112) até uma deflexão de $3 \mathrm{~mm}$ a velocidade de $2 \mathrm{~mm} / \mathrm{min}$. As medições foram feitas sob água em temperatura constante de $37^{\circ} \mathrm{C} \pm 0,5^{\circ} \mathrm{C}$ nas fases de carregamento e descarregamento. O fio .020" apresentou força máxima de aproximadamente $4,0 \mathrm{~N}(392 \mathrm{~g})$ a $3 \mathrm{~mm}$ de ativação, com média no platô de desativação de 1,5N (147g). Esses valores foram de, respectivamente, 2,8N (274g) e $0,7 \mathrm{~N}(67 \mathrm{~g})$ para o fio .018 " e de 2,0N (196g) e 0,7N (67g) para o .016". Esses resultados demonstraram que o fator de maior importância é a transformação martensítica, onde a rigidez da liga colapsa e o módulo de elasticidade diminui. A resistência ao dobramento não pode ser diretamente relacionada à dimensão transversal do fio, onde existe processo de superelasticidade, apesar de que essa dimensão influi nos valores de força desenvolvidos pelo fio.

Stamm et al. (2004) avaliaram em seu estudo a precisão de dobras de terceira ordem em fios de níquettitânio e determinou o efeito do uso de pressão alta ou baixa para manter a forma do fio durante o tratamento térmico de memorização de forma. Uma máquina computadorizada foi usada para incorporar 200 ângulos de torção entre $0^{\circ}$ e $60^{\circ}$ em 30 segmentos lineares de fio $.016^{\prime \prime} \times .022$ " (NeoSentalloy F80, GAC International, Central Islip, NY). Os dobramentos de torção foram 
distribuídos aleatoriamente em 2 grupos. Os fios do grupo 1 ( $n=100)$ receberam tratamento térmico sob pressão de 1,6 MPa (16 bar) e os do grupo $2(n=100)$ sob pressão de $50 \mathrm{MPa}$ (500 bar). Os resultados mostraram que dobras de torque de até $30^{\circ}$ podem ser executadas com precisão clínica adequada com erro de $1,89^{\circ} \pm$ $1,75^{\circ}\left(0^{\circ}\right.$ a $\left.10^{\circ}\right)$ e de $3,5^{\circ}\left(20^{\circ}\right.$ a $\left.30^{\circ}\right)$, independentemente da pressão aplicada. Para dobras entre $30^{\circ}$ e $40^{\circ}$, o método com alta pressão oferece, fundamentalmente, maior precisão do que aquele com baixa pressão. Com dobras acima de $40^{\circ}$ ambos os métodos mostraram erros clinicamente inaceitáveis. Além disso, devido à variabilidade em dimensão e composição dos arcos de níquettitânio, o nível de deformação plástica incorporada contribuiu substancialmente para os níveis de erro. Assim, as dobras de terceira ordem deveriam ser distribuídas pela maior extensão possível do fio, se a situação clínica permitir. 


\section{PROPOSIÇÃO}

O presente estudo teve por objetivo avaliar a super-elasticidade de fios ortodônticos de níquel-titânio, abordando os fatores e níveis:

3.1 Ativar e desativar os fios por meio de diferentes deflexões máximas $(1,2,3$ e $4 \mathrm{~mm}$ ), registrando os pares de valores força x deflexão para análise.

3.2 Ensaiar 3 marcas de fios (Forestadent, GAC e Morelli).

3.3 Realizar os ensaios em 3 diferentes temperaturas $\left(32,37\right.$ e $\left.40^{\circ} \mathrm{C}\right)$. 


\section{MATERIAL E MÉTODOS}

\subsection{Material, Instrumental, Dispositivos e Aparelhos}

Os materiais, instrumental, dispositivos e aparelhos são apresentados em lista, a fim de evitar no texto a citação dos dados dos fabricantes, tornando a leitura mais fluida.

\subsection{1 material, instrumental e dispositivos}

- $\quad$ Arcos de ligas de níqueltitânio (NiTi) com propriedades de superelasticidade, de secção circular com diâmetro de.016" (16 milésimos de polegada - ou $0,406 \mathrm{~mm}$ )

- 60 arcos Forestadent (Forestadent - Pforzheim, Germany), lote $294 / 26384$

- 60 arcos GAC (GAC - Islip, NY, EUA), lote G15083

- 60 arcos Morelli (Morelli - São Paulo, Brasil), lote 581445

- Um conjunto de bráquetes de aço inoxidável, para a técnica Edgewise Standard, sem torque ou angulações incorporados, slot .022" ou 0,559 mm (Morelli, São Paulo, Brasil)

- Amarrilhos elásticos standard incolor (Uniden - São Carlos, Brasil)

- Cola rápida de cianoacrilato em gel (Super Bonder, Henkel/Loctite - Brasil)

- Pinça para colagem

- Posicionador de bráquetes 
- Alicate de corte

- Instrumento para instalar e remover amarrilhos elásticos

- Termômetro digital para controlar a temperatura no ambiente do ensaio

- Chave de fenda

- Modelo de simulação clínica (Figuras 4.1 a 4.5)

\subsubsection{Aparelhos}

- Máquina de ensaios universal Instron modelo 5565 (Instron Co., Canton, MA, USA), com ponta adaptada para o deslocamento do braquete com o fio, durante os ensaios

- Câmera térmica Eurotherm (Eurotherm Controls Ltd, Faraday Close, Durrington, UK), para manutenção da temperatura.

\subsection{Métodos}

Os ensaios de força, em função da deflexão do fio ortodôntico, foram realizados em um modelo de simulação clínica, uma vez que o ensaio simples de três pontos se afasta muito da realidade encontrada no meio bucal (Figuras $4.1 \mathrm{a}$ 4.5).

O modelo de simulação clínica baseou-se em trabalhos de autores (ROCK; WILSON, 1988; GURGEL et al., 2001b; HEMINGWAY et al., 2001), que o empregaram em várias pesquisas.

A Figura 4.1 representa uma placa de resina acrílica com 12 perfurações, correspondentes ao mesmo número de cilindros metálicos, que representam os 
dentes, com os bráquetes colados com cianoacrilato em gel (Figuras 4.2 e 4.3). No outro lado da placa, os dentes foram fixados por meio de parafusos (Figura 4.4).

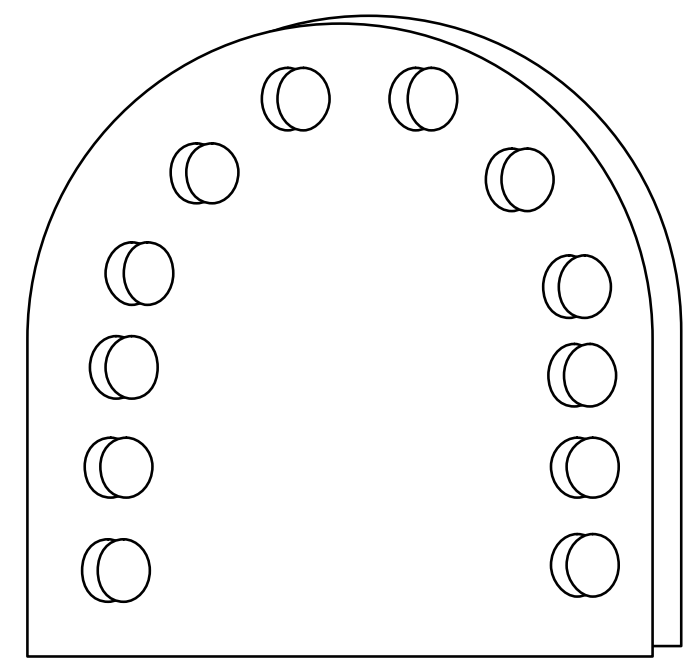

Figura 4.1 - Placa de resina acrílica perfurada

Os arcos foram amarrados com os amarrilhos elásticos. A Figura 4.4 mostra o modelo de simulação clínica.

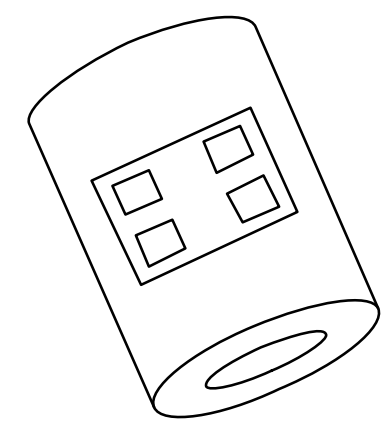

Figura 4.2 - Cilindro metálico com bráquete colado

O espaço entre os braquetes foi de $8 \mathrm{~mm}$, que foi mantido constante, uma vez que a relação força deflexão é dependente, entre outros aspectos, dessa distância. 
Os ensaios foram feitos em sítio correspondente a incisivo central superior. O cilindro correspondente ao dente de ensaio foi desparafusado da placa de resina, continuando, porém, amarrado ao arco, para não alterar a distância interbraquetes.

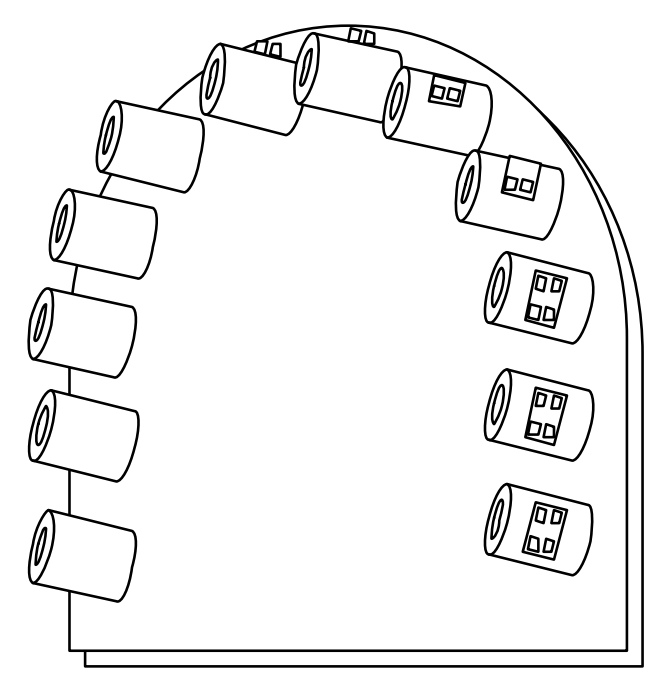

Figura 4.3 - Placa de resina acrílica com os cilindros metálicos parafusados e bráquetes colados

A deflexão, ou afastamento do bráquete com o arco, foi feita com uma ponta com terminação retangular, para se apoiar nas 4 aletas desse bráquete. A outra extremidade da ponta ativadora foi fixada na máquina de ensaios para promover o deslocamento. O modelo de simulação clínica foi fixado com nivelamento adequado, para que a linha de ação da força ativadora atuasse perpendicularmente ao plano do bráquete. A Figura 4.5 mostra a condução dos ensaios.

A velocidade da máquina de ensaio para o deslocamento, tanto no carregamento como no descarregamento, foi de $0,5 \mathrm{~mm} / \mathrm{min}$. 
A movimentação do braquete com o arco corresponderia à ativação, clinicamente, no aumento da força e a desativação seria após cessar essa força que provocou a deflexão. Esta corresponderia ao período clínico da movimentação dentária.

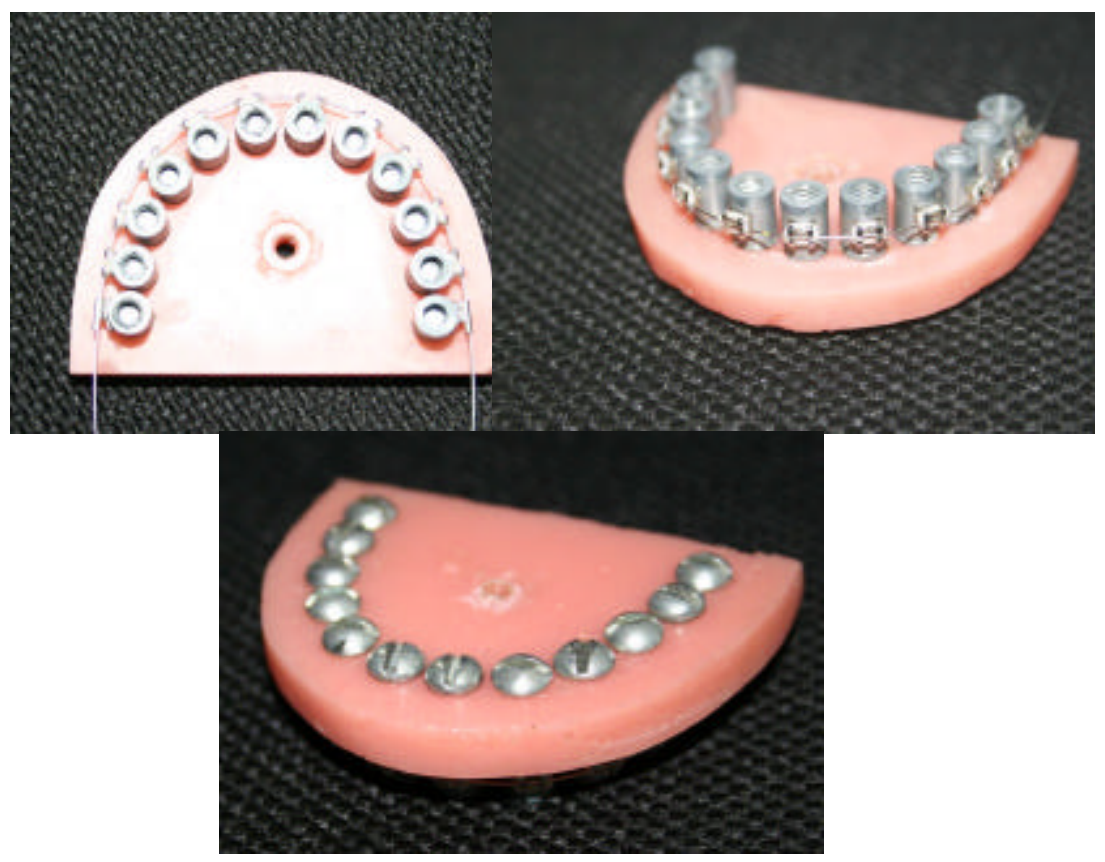

Figura 4.4 - Modelo de simulação clínica

A ativação no presente trabalho, também, pode ser chamada de carregamento e a desativação de descarregamento. O deslocamento em relação à origem (a partir da posição inicial do bráquete), é chamado de afastamento.

Os registros, dentro da programação da máquina com o software, da força e afastamento correspondente, durante a ativação e desativação, foram feitos de 0,10 em $0,10 \mathrm{~mm}$ que forneceram os valores numéricos e os gráficos correspondentes a esses valores. 


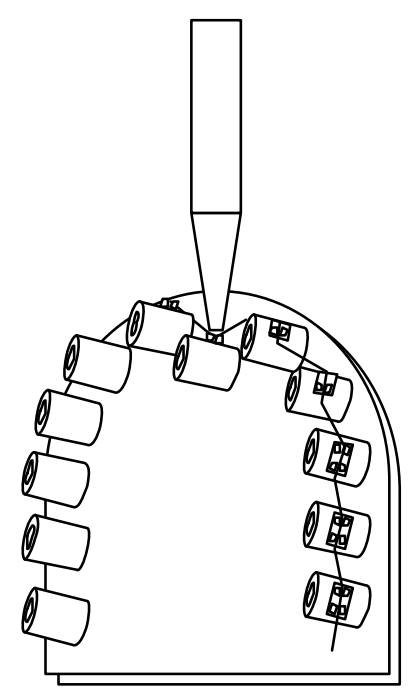

Figura 4.5 - Ponta da máquina Instron executando deslocamento sobre o cilindro metálico desparafusado

As ativações e desativações até força zero foram feitas até os afastamentos máximos de 1, 2, 3 e 4 mm.

As temperaturas de ensaio foram: 32,37 e $42^{\circ} \mathrm{C}\left( \pm 1^{\circ} \mathrm{C}\right)$.

Os fios, conforme visto, foram de 3 marcas.

O esquema fatorial, portanto, foi: 4 ativações $\times 3$ marcas $\times 3$ temperaturas $=36$ condições experimentais. Com 5 repetições $(n=5)$, fizeram-se 180 ensaios.

Os pares de valores (força e afastamento) obtidos durante os ensaios conduziram aos gráficos como representados na Figura 4.6.

A quantidade de números obtidos foi muito grande e sua análise seria extensa demais, além de não ter tanto interesse prático. Em virtude disso, tomourse valores particulares da desativação dos gráficos e tabelas, que conduzissem a informações de interesse clínico. A figura 4.6 mostra que com ativações de 1 e 2 $\mathrm{mm}$ nem sequer manifestourse a superelasticidade, o que foi observado apenas com 3 e 4 mm de ativação máxima. 
Pontos escolhidos para avaliação

Os pontos escolhidos para fazer avaliação foram de A a G. Pela ausência da manifestação da superelasticidade, nas ativações de 1 e $2 \mathrm{~mm}$ não aparecem os pontos C, D e E (Figura 4.6).

- Ponto A - Corresponde às forças máximas nas ativações máximas.

- Ponto B - Diminuição da força com desativação de 0,20 mm, a partir da máxima.

- Ponto C - Diminuição da força com desativação de 0,70 mm, a partir da máxima (3 e 4mm de ativação).

- Pontos D a E - Extensão e força do platô de superelasticidade. O segmento correspondente ao platô nem sempre era rigorosamente paralelo ao eixo do afastamento. Assim, para obtê-lo foram fixados os seguintes critérios: início do platô-com registros de pelo menos 2 forças iguais em seqüência (distância mínima de 0,10 mm); final do platô, quando a força registrada era \pm 20 g, em relação à inicial. A extensão era o segmento entre essas forças. A força no platô de cada ensaio foi obtido por média ponderada das forças (extensão e força avaliadas apenas nas ativações máximas de 3 e 4 mm).

- Ponto $\mathrm{F}$ - Corresponde à desativação até registrar $50 \mathrm{~g}$ de força a partir de 0,80 e 1,80 $\mathrm{mm}$ (respectivamente 1 e $2 \mathrm{~mm}$ de ativação) e a partir do final do platô (com ativação de 3 e 4 mm). Em relação a esse ponto foram feitas 3 avaliações: 1) valor da extensão de desativação até registrar $50 \mathrm{~g}$ de força; 2) força registrada ao 
iniciar-se a referida extensão; 3) valor do afastamento da origem ao atingir $50 \mathrm{~g}$ de força.

- Ponto G - Afastamento (da origem) ao atingir a força zero. Corresponde à deformação residual. 

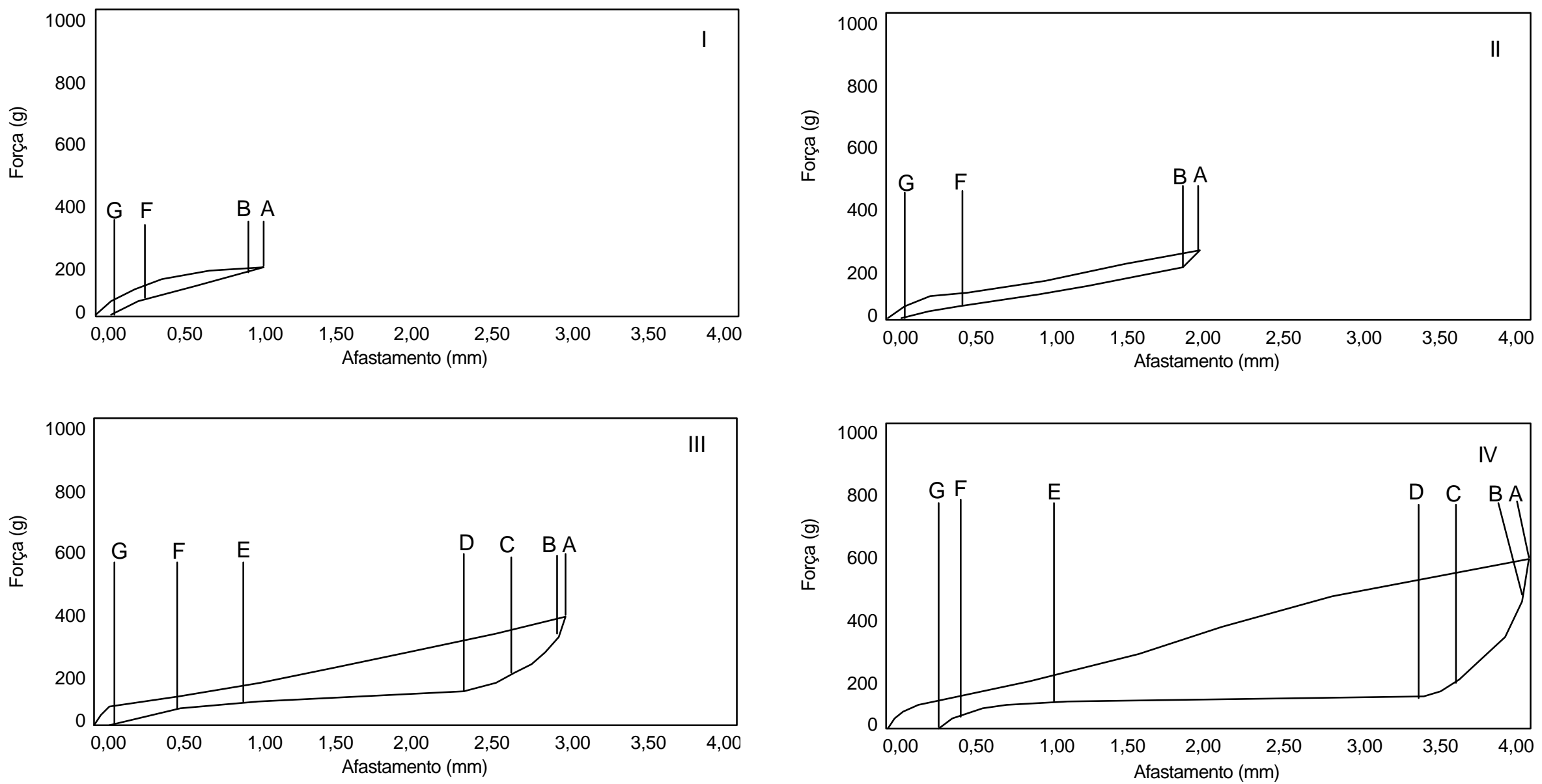

Figura 4.6 - Curvas de ativação e desativação (força = função do afastamento da origem). Afastamento até (mm): I, 1mm; II, 2mm; III, 3mm; IV, $4 \mathrm{~mm}$ 
Análise estatística dos dados colhidos

Os dados individuais colhidos, conforme visto, encontram-se nas Tabelas do Apêndice. Os gráficos das médias das 36 condições experimentais encontram-se no capítulo de resultados (Figuras 5.1 a 5.4)

Os dados colhidos foram submetidos a análise de variância para cada grandeza determinada. As médias, quando pertinente, foram contrastadas pelo teste de Tuckey, com a $=5 \%$. Nos casos em que apareciam as 4 ativações máximas (1, 2, 3 e $4 \mathrm{~mm})$, a análise consistia de 36 condições experimentais. Já nos casos em que só foram envolvidas as ativações máximas de 3 e $4 \mathrm{~mm}$, a análise era conduzida com 18 condições experimentais. 


\section{RESULTADOS}

Os resultados serão apresentados por grandeza analisada. Entretanto, as tabelas serão colocadas no final do capítulo em seqüência, devido ao grande número. Para melhor visualização das grandezas, foram colocados os gráficos das médias de cada uma das 36 condições experimentais (Figuras 5.1 a 5.4), localizadas antes das Tabelas.

Para cada grandeza foram apresentadas a análise de variância, as medidas correspondentes aos fatores principais e as correspondentes à interação dos três fatores estudados. São 36 condições experimentais quando incluir as 4 ativações máximas e apenas 18, quando as grandezas envolvidas forem relacionadas apenas com 3 e 4mm de ativação máxima.

\subsection{Forças nas ativações máximas}

As Tabelas 5.1 a 5.3 apresentam os resultados das forças nas ativações máximas. A tabela 5.1 apresenta a análise de variância. A Tabela 5.2 apresenta as médias correspondentes aos fatores principais (ativação, marca e temperatura) e a Tabela 5.3 contém as médias correspondentes à interação ativação $x$ marca $x$ temperatura ou das 36 condições experimentais.

A análise de variância (Tabela 5.1) mostra que todos os fatores principais, bem como as interações correspondentes foram significantes. 
A Tabela 5.2 mostra que o fator ativação foi significante e há diferenças significantes entre as 4 médias, que são crescentes da ativação de $1 \mathrm{~mm}(213 \mathrm{~g})$ até $4 \mathrm{~mm}$ (537g). As três marcas de material também apresentaram diferenças significantes entre si. O menor corresponde à Morelli $(320 \mathrm{~g})$ e o maior à GAC (399g). A temperatura de ensaio mostrou valores crescentes significantemente com a mesma. De $32^{\circ} \mathrm{C}(333 \mathrm{~g})$ a $42^{\circ} \mathrm{C}(389 \mathrm{~g})$.

Os resultados vistos para os fatores principais, notam-se, em linhas gerais, nas médias das diferentes condições experimentais (Tabela 5.3), quer apenas numericamente, quer significantemente. Notam-se os valores crescentes com o aumento da temperatura de ativação, embora nem sempre a diferença caracterize significância. A marca GAC chegou a $680 \mathrm{~g}\left(37^{\circ} \mathrm{C}\right)$, ou $674 \mathrm{~g}\left(42^{\circ} \mathrm{C}\right)$, valores bem altos e não diferentes significantemente entre si.

\subsection{Diminuição da força com desativação de $0,20 \mathrm{~mm}$, a partir da máxima}

As Tabelas 5.4 a 5.6 apresentam os resultados das análises.

A Tabela 5.4 mostrou que todos os fatores principais foram significantes, bem como todas as interações correspondentes.

A Tabela 5.5, que apresenta as médias dos fatores principais mostra que quanto maior a força necessária para a ativação máxima, maior é a diminuição nos primeiros $0,20 \mathrm{~mm}$ de desativação. Na ativação de $4 \mathrm{~mm}$ a força caiu $264 \mathrm{~g}$ enquanto na ativação de $1 \mathrm{~mm}$, a queda foi apenas de $52 \mathrm{~g}$. quanto à marca, nota-se um certo paralelismo entre força máxima alcançada e queda no início da desativação. 
A marca GAC apresentou a maior força na ativação e também a maior na queda. Por sua vez, com a menor força de ativação máxima, menor foi a queda na desativação inicial da marca Morelli. A temperatura também influenciou semelhantemente na queda inicial como na ativação máxima.

A Tabela 5.6, correspondente às médias das 36 condições experimentais mostra, também, as diferenças vistas para as médias dos fatores principais (Tabela 5.5), quer significantemente, quer apenas numericamente.

\subsection{Diminuição da força com desativação de $0,70 \mathrm{~mm}$ a partir da máxima}

Conforme já foi lembrado, devido às características das curvas de ativação/desativação, no caso foram analisadas apenas aquelas de ativação de 3 e $4 \mathrm{~mm}$. Os valores de forças correspondentes à desativação de $0,70 \mathrm{~mm}$ encontramse próximas dos inícios dos platôs.

As Tabelas 5.7 a 5.9 apresentam os resultados dessas análises.

A análise de variância (Tabela 5.7) mostrou diferenças significantes em todos os fatores principais e também todas as interações correspondentes.

A Tabela 5.8 apresenta as médias correspondentes aos fatores principais. Verifica-se que, na ativação de 4mm, a diminuição foi muito acentuada (436g), quando a força na ativação máxima foi de $537 \mathrm{~g}$ (Tabela 5.2). A marca GAC apresentou a maior queda, que também parece estar relacionada com a força máxima na ativação (Tabela 5.2). O menor valor corresponde à marca Morelli (307g) que, também, apresenta relação com os valores da Tabela 5.2. 
A queda da força tem, também, relação com a temperatura. Entretanto, entre as de $37^{\circ} \mathrm{C}(353 \mathrm{~g})$ e $42^{\circ} \mathrm{C}(361 \mathrm{~g})$ não houve diferença significante.

A Tabela 5.9 apresenta as médias correspondentes à interação ativação $x$ marca $x$ temperatura, ou seja, às 18 condições experimentais (ativação máxima de 3 e $4 \mathrm{~mm}$ ). Nas três temperaturas e com os três materiais, sempre houve grandes diferenças e, significantemente, entre as ativações de 3 e $4 \mathrm{~mm}$. Entre temperaturas, para mesmas ativações, encontram-se diferenças apenas com o material GAC, na ativação máxima de $4 \mathrm{~mm}$.

\subsection{Extensão dos platôs}

As Tabelas 5.10 e 5.12 apresentam os valores das análises dos platôs da superelasticidade, nas ativações máximas de 3 e $4 \mathrm{~mm}$.

Essa grandeza, juntamente com a do seguinte item (força durante o platô) representam grande importância relativamente à superelasticidade e suas implicações clínicas.

Os resultados da análise de variância (Tabela 5.10) mostraram que os três fatores principais foram significantes. Das interações apenas não foi significante a ativação $\times$ marca.

A Tabela 5.11 apresenta as médias correspondentes aos três fatores principais. A ativação máxima de $4 \mathrm{~mm}$ apresenta uma extensão bem maior que a de $3 \mathrm{~mm}$ e altamente significante. O fato é quase autoexplicativo, já que a deformação foi menor nessa última. As marcas Forestadent e GAC apresentam valores maiores que a Morelli $(1,76$ e 1,82mm, respectivamente, contra 1,22 da 
Morelli). A temperatura de $32^{\circ} \mathrm{C}$ apresentou o menor valor significantemente comparada com 37 e $42^{\circ} \mathrm{C}$.

A Tabela 5.12 apresenta as médias correspondentes à interação ativação $x$ marca $x$ temperatura. Verifica-se que a $32^{\circ} \mathrm{C}$, tanto na ativação de $3 \mathrm{~mm}$ como na de $4 \mathrm{~mm}$, a marca Morelli apresentou as menores extensões dos platôs, significantemente. Nas demais temperaturas $\left(37\right.$ e $\left.42^{\circ} \mathrm{C}\right)$ os três materiais apresentaram valores semelhantes, tanto na de 3 como na de $4 \mathrm{~mm}$ de ativação.

As médias correspondentes à ativação máxima de $3 \mathrm{~mm}$, apresentaram o início do platô,geralmente um pouco acima do afastamento de $2 \mathrm{~mm}$ (cerca de 10\% a mais) e o término ocorria, em geral, um pouco acima de $1 \mathrm{~mm}$. Com a ativação máxima de $4 \mathrm{~mm}$, com platô mais extenso, o seu início ocorria pelo afastamento de $3 \mathrm{~mm}$ (com mais 10\%), mas o término,geralmente era até com menos de $1 \mathrm{~mm}$.

\subsection{Força média ponderada ao longo do platô}

As Tabelas 5.13 a 5.15 apresentam os resultados das análises das forças no platô. Sem dúvida esta grandeza é de grande importância clínica.

A análise de variância (Tabela 5.13) mostrou significância para os três fatores principais e a interação ativação $x$ marca, não tendo sido significante nenhuma outra interação.

As médias da Tabela 5.14 mostram que a força média, com $4 \mathrm{~mm}$ de ativação, foi bem menor do que com 3mm (3mm: 132g; 4mm: 103g). A marca Morelli conduziu a um valor bem baixo, significativamente. Por outro lado, quanto maior a temperatura, maior significantemente foi a força ao longo do platô. 
A Tabela 5.15 apresenta as médias correspondentes às 18 condições experimentais. Verifica-se que sempre a marca Morelli apresenta menor valor, quando comparada com as demais, isso para as três temperaturas e duas ativações.

\subsection{Extensão na desativação até atingir a força de $50 \mathrm{~g}$, a partir de $0,80 \mathrm{e}$ $1,80 \mathrm{~mm}$ (respectivamente 1 e $2 \mathrm{~mm}$ de ativação) e a partir do final do platô} (3 e $4 \mathrm{~mm}$ de ativação)

As Tabelas 5.16 a 5.18 contem os resultados da análise da extensão até atingir a força de $50 \mathrm{~g}$.

A análise de variância da Tabela 5.16 mostra que foram significantes todos os fatores principais, bem como todas as interações correspondentes.

A Tabela 5.17 contém as médias dos fatores principais. A ativação de $2 \mathrm{~mm}$ apresenta uma extensão de $1,27 \mathrm{~mm}$, desde aquém de $1,8 \mathrm{~mm}$ até a força diminuir até $50 \mathrm{~g}$. Com ativação de $1 \mathrm{~mm}$, fica disponível o valor de 0,40mm. Por outro lado, após terminarem os platôs, nas ativações de 3 e 4mm, os valores, também, são bem mais baixos, principalmente no caso da ativação de $4 \mathrm{~mm}$. Todos os valores, nas 4 ativações, foram significantemente diferentes entre si. A marca Forestadent apresentou o valor maior significantemente $(0,67 \mathrm{~mm})$, comparado com a $\operatorname{GAC}(0,52 \mathrm{~mm})$ e a Morelli $(0,54 \mathrm{~mm})$. A temperatura de $32^{\circ} \mathrm{C}$ apresentou o menor valor significantemente e entre $37^{\circ} \mathrm{C}$ e $42^{\circ} \mathrm{C}$ não houve diferença.

A Tabela 5.18, correspondentes às 36 condições experimentais, mostra que houve muitos valores bem baixos (menor que 0,20mm). Um deles foi, inclusive, negativo (Morelli, com ativação de $4 \mathrm{~mm}$ e temperatura de $32^{\circ} \mathrm{C}$ ). Isto se explica pelo 
fato do platô ter alcançado força menor de $50 \mathrm{~g}$ antes de terminar, ou seja, $0,48 \mathrm{~mm}$ antes. A Tabela 5.18 mostra ainda que, em linhas gerais, a temperatura influenciou mais na marca Morelli com ativação de $4 \mathrm{~mm}$.

\subsection{Força ao iniciar a desativação até $50 \mathrm{~g}$, em 0,80 e 1,80mm (respectivamente 1 e $2 \mathrm{~mm}$ de ativação) e no final do platô ( 3 e $4 \mathrm{~mm}$ de ativação)}

As Tabelas 5.19 a 5.21 apresentam os resultados dessas forças. A Tabela 5.19 mostra significância para todos os fatores principais. Das interações com exceção de marca $x$ temperatura, todas, também, foram significantes.

A Tabela 5.20 apresenta o maior valor para a ativação de $2 \mathrm{~mm}(217 \mathrm{~g})$ e o menor para $4 \mathrm{~mm}$ de ativação (81g). As 4 ativações apresentam valores significantemente diferentes entre si. A marca Forestadent apresenta, em média, o maior valor (163g) e a Morelli o menor (122g). O aumento da temperatura mostrou nitidamente aumento médio das forças: $32^{\circ} \mathrm{C}(123 \mathrm{~g}) ; 37^{\circ} \mathrm{C}(149 \mathrm{~g}) ; 42^{\circ} \mathrm{C}(166 \mathrm{~g})$.

A Tabela 5.21 apresenta as médias correspondentes às 36 condições experimentais. Verifica-se o baixo valor (28g) para a condição Morelli $4 \mathrm{~mm} / 32^{\circ} \mathrm{C}$, o que está coerente com o valor negativo correspondente à extensão da Tabela 5.18. A Tabela 5.21 mostra ainda que a ativação de $1 \mathrm{~mm}$ sofreu influência significante da temperatura apenas na marca GAC. O mesmo já não foi válido para a ativação de $2 \mathrm{~mm}$, onde se observam maiores valores com maior temperatura. Com ativação de 3 e $4 \mathrm{~mm}$, o comportamento, também, depende de outros fatores.

\subsection{Afastamento da origem ao registrar $50 \mathrm{~g}$ de força na desativação}


As Tabelas 5.22 e 5.24 apresentam os resultados das análises dessa grandeza.

A Tabela 5.22, correspondente à análise de variância, mostrou que, também, todos os fatores principais e todas as interações correspondentes foram altamente significantes $(p<0,000)$.

As médias da Tabela 5.23 mostraram um aumento gradativo conforme ativação de $0,40 \mathrm{~mm}$ ( $1 \mathrm{~mm}$ de ativação) até $0,94 \mathrm{~mm}$ ( $4 \mathrm{~mm}$ de ativação). Essa Tabela ainda mostra que a marca Morelli apresentou o maior afastamento e a Forestadent o menor. A temperatura influenciou pouco, havendo semelhança entre as médias correspondentes a $37^{\circ} \mathrm{C}$ e $42^{\circ} \mathrm{C}$. A $32^{\circ} \mathrm{C}$ o valor foi significantemente maior.

As médias correspondentes às 36 condições experimentais (Tabela 5.24) mostraram que,geralmente, há com grande freqüência semelhança entre elas. Um valor que chama atenção é o correspondente à marca Morelli, com ativação de 4mm e temperatura de $32^{\circ} \mathrm{C}$. O valor se destaca dos demais pela grande diferença numérica e significa isto que os $50 \mathrm{~g}$ de força já foram atingidos com afastamento ainda bem grande da origem.

\subsection{Afastamento ou deformação permanente ou residual ao alcançar força zero na desativação}

As Tabelas 5.25 a 5.27 apresentam as análises dessa grandeza, com força zero. 
A análise de variância (Tabela 5.25) mostrou significância para os fatores principais e interações de 2 fatores. Não tendo sido significante a interação dos 3 fatores (ativação x marca x temperatura).

As médias correspondentes aos fatores principais (Tabela 5.26) mostraram que, embora diferença significante entre as 4 ativações, a diferença numérica, a rigor não é tão acentuada. A menor diferença residual foi da marca Forestadent $(0,23 \mathrm{~mm})$ e a maior corresponde às marcas GAC e Morelli, não diferentes entre si significantemente. A menor deformação permanente corresponde à temperatura de $37^{\circ} \mathrm{C}$ e a maior à de $32^{\circ} \mathrm{C}$, não tendo sido encontrados valores crescentes ou decrescentes com as 3 temperaturas.

A Tabela 5.27 corresponde à interação ativação $x$ marca $x$ temperatura, ou às 36 condições experimentais. Mostra a Tabela que,geralmente não foram encontradas diferenças significantes, havendo bastante semelhança entre muitas delas. Na temperatura de $37^{\circ} \mathrm{C}$ foram encontrados os maiores valores em ativações maiores e com as marcas GAC e Morelli. 


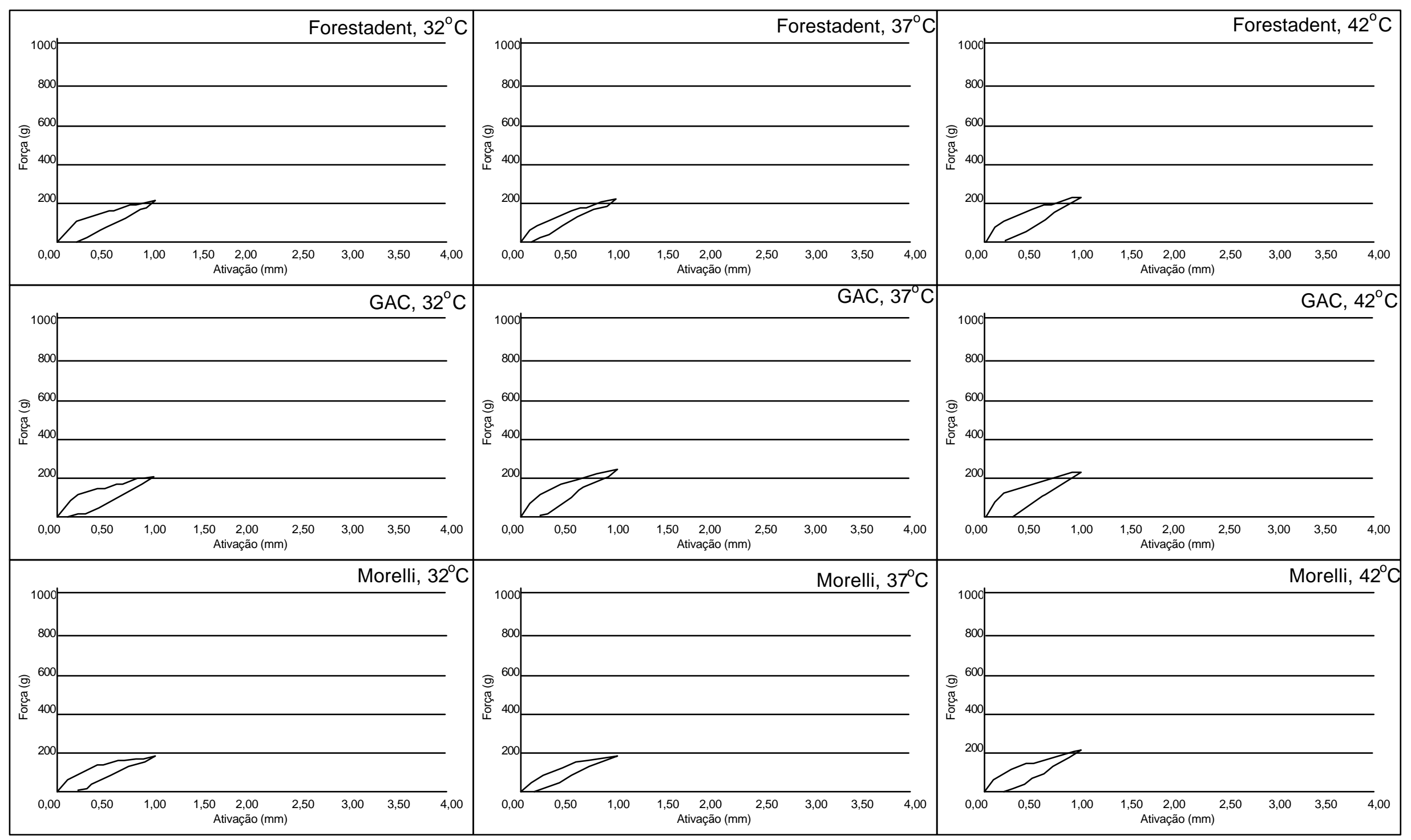

Figura 5.1 - Curvas de ativação e desativação (força = função do afastamento da origem) para os fios Forestadent, GAC e Morelli, nas temperaturas de $32^{\circ} \mathrm{C}$, $37^{\circ} \mathrm{C}$ e $42^{\circ} \mathrm{C}$, com ativação de $1,0 \mathrm{~mm}$ 

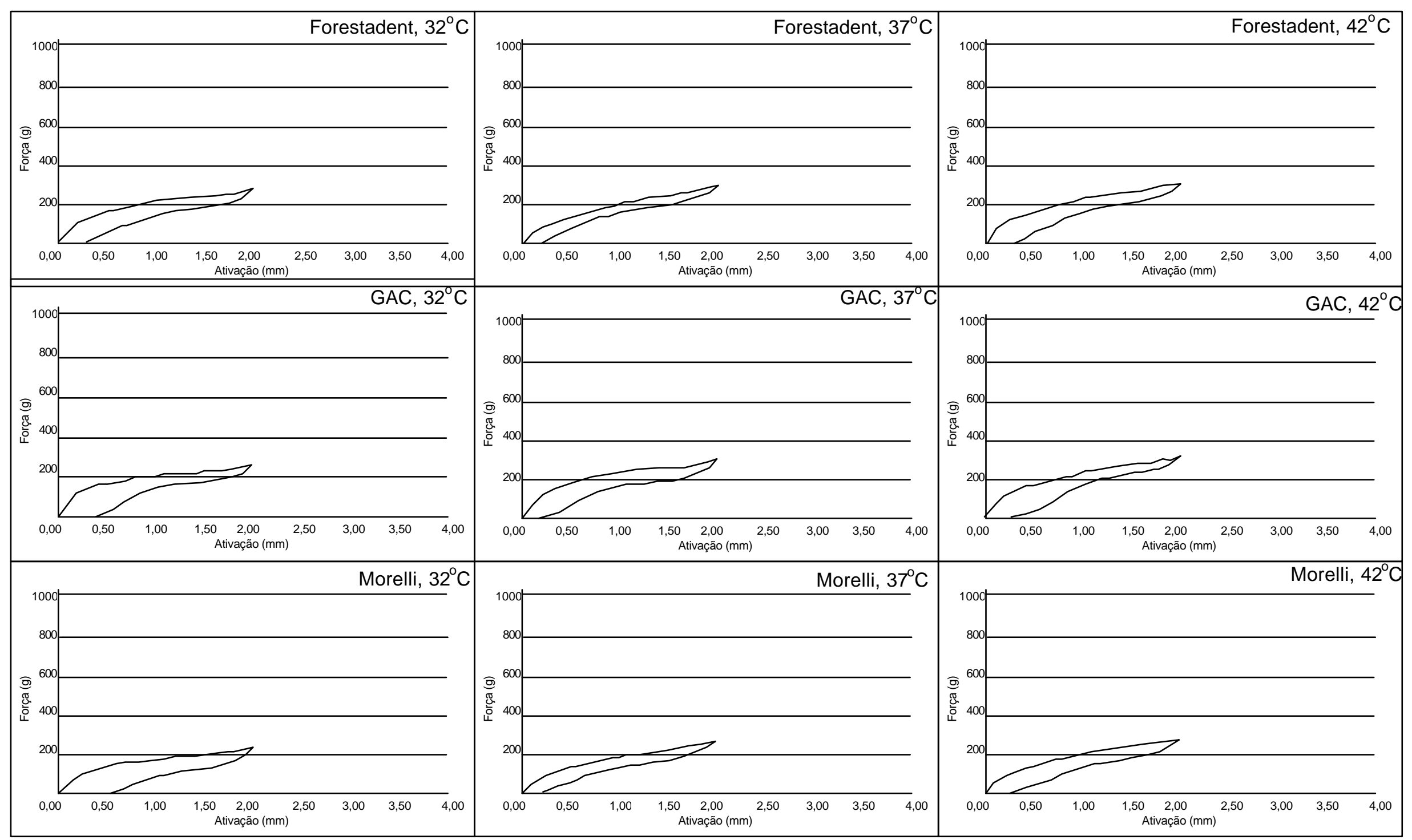

Figura 5.2 - Curvas de ativação e desativação (força = função do afastamento da origem) para os fios Forestadent, GAC e Morelli, nas temperaturas de $32^{\circ} \mathrm{C}$, $37^{\circ} \mathrm{C}$ e $42^{\circ} \mathrm{C}$, com ativação de $2,0 \mathrm{~mm}$ 


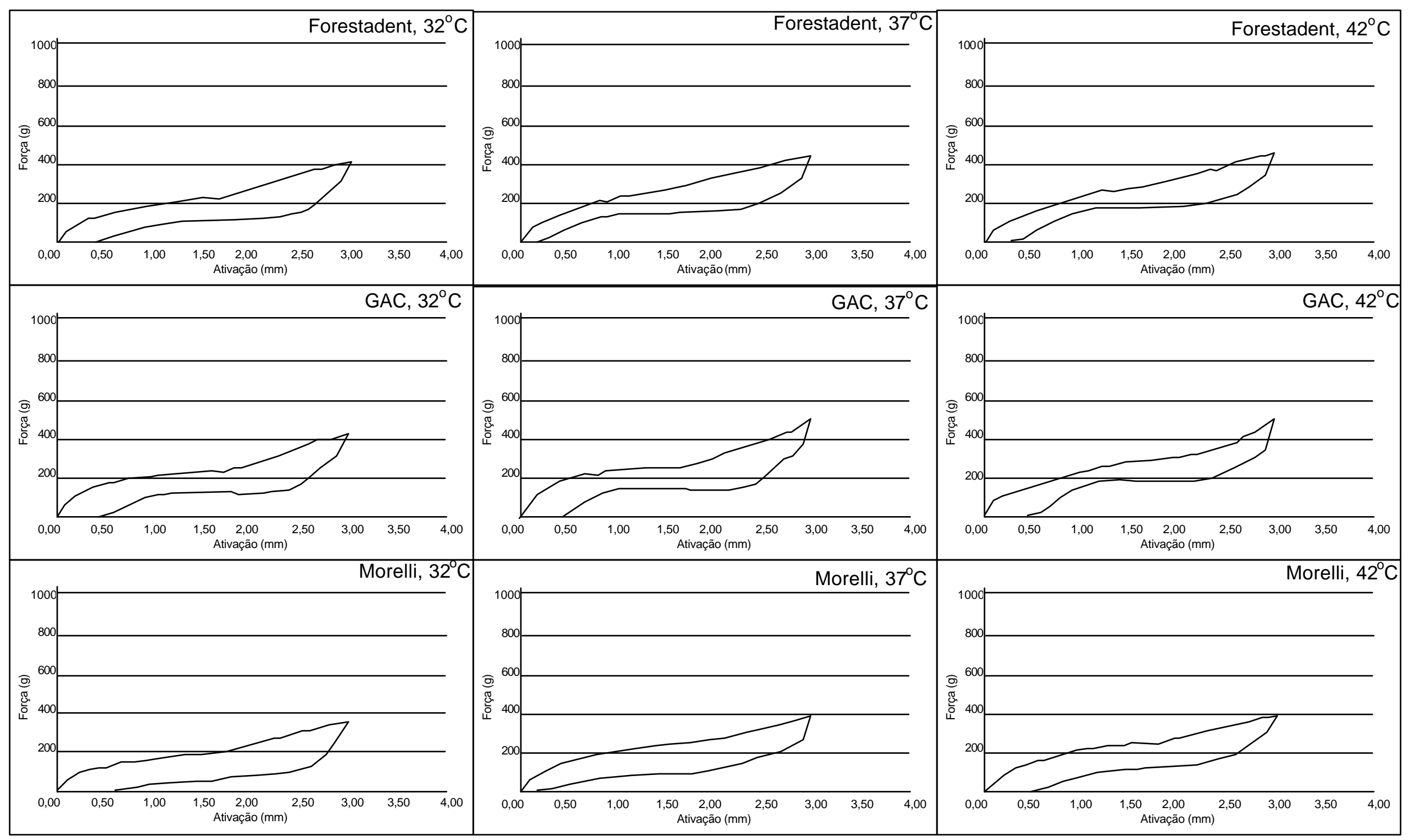

Figura 5.3 - Curvas de ativação e desativação (força = função do afastamento da origem) para os fios Forestadent, GAC e Morelli, nas temperaturas de $32^{\circ} \mathrm{C}$, $37^{\circ} \mathrm{C}$ e $42^{\circ} \mathrm{C}$, com ativação de $3,0 \mathrm{~mm}$ 


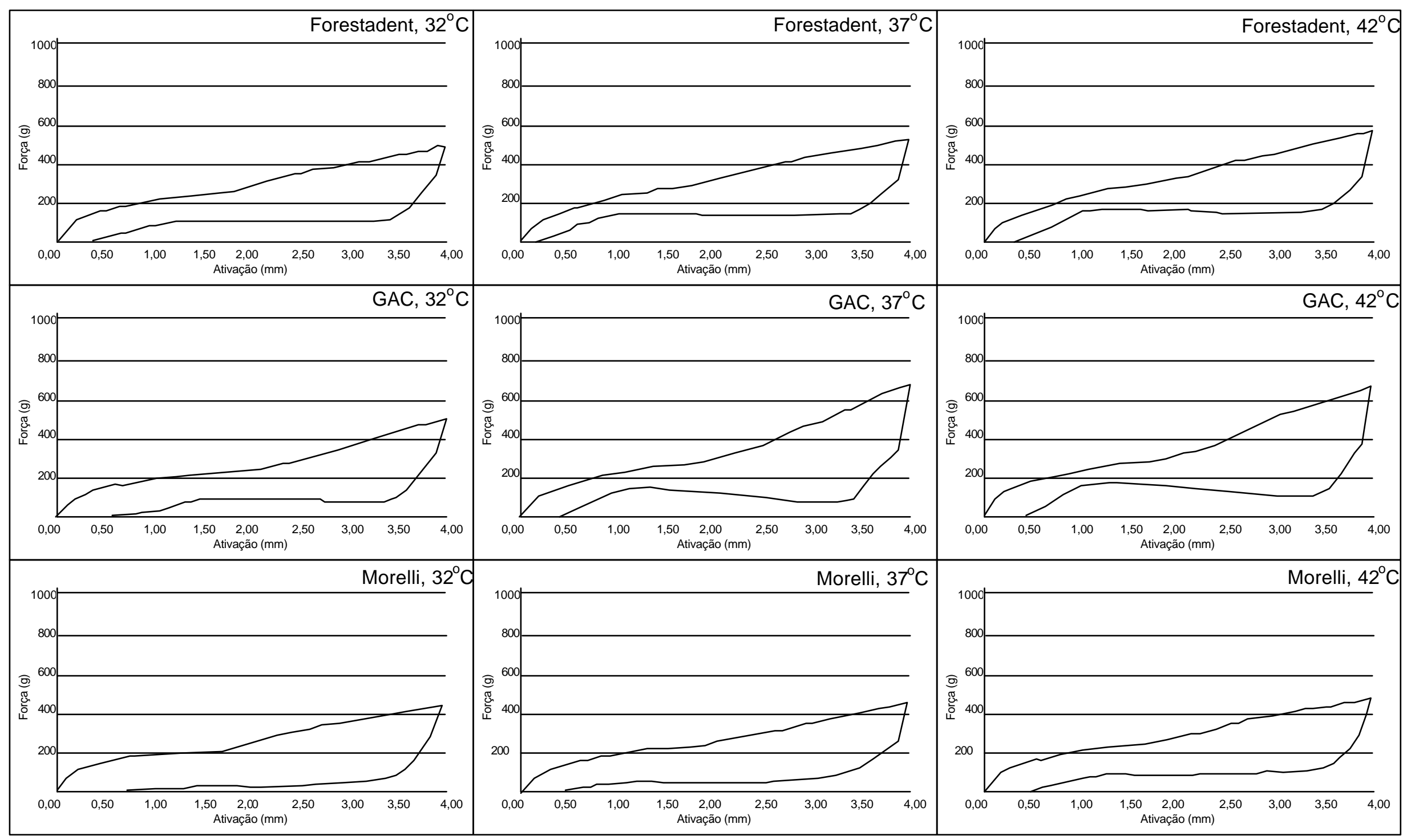

Figura 5.4 - Curvas de ativação e desativação (força = função do afastamento da origem) para os fios Forestadent, GAC e Morelli, nas temperaturas de $32^{\circ} \mathrm{C}$, $37^{\circ} \mathrm{C}$ e $42^{\circ} \mathrm{C}$, com ativação de $4,0 \mathrm{~mm}$ 
Tabela 5.1 - Análise de variância das forças máximas registradas nas diversas ativações

\begin{tabular}{l|c|c|r|c}
\hline Fonte de variação & G.L. & Quadrados médios & R.Q.M. & $\begin{array}{c}\text { Probabilidade } \\
\left(\mathrm{H}_{0}-\%\right)\end{array}$ \\
\hline Ativação (A) & 3 & $940.090,0625$ & $1.592,46$ & 0,000 \\
Marca do fio (M) & 2 & $95.707,3359$ & 162,12 & 0,000 \\
Temperatura (T) & 2 & $49.407,6016$ & 83,69 & 0,000 \\
Interação A x M & 6 & $15.610,7803$ & 26,44 & 0,000 \\
Interação M x T & 4 & $4.675,1313$ & 7,92 & 0,005 \\
Interação A x T & 6 & $3.375,0466$ & 5,72 & 0,009 \\
Interação A x M x T & 12 & $2.344,2991$ & 3,97 & 0,009 \\
Resíduo & 144 & 590,3389 & - & - \\
Total & 179 & - & - & - \\
\hline
\end{tabular}

Tabela 5.2 - Médias (g) das forças máximas dos fatores principais (ativação, marca e temperatura) e valores críticos para contrastes *

\begin{tabular}{|c|c|c|c|c|}
\hline \multicolumn{4}{|c|}{ Ativação (mm) } & \multirow{2}{*}{ Tuckey (5\%) } \\
\hline 1 & 2 & 3 & 4 & \\
\hline $213 d$ & $283 \mathrm{c}$ & $422 \mathrm{~b}$ & $537 \mathrm{a}$ & 13,3 \\
\hline \multicolumn{4}{|c|}{ Marca } & - \\
\hline Forestadent & & & Morelli & - \\
\hline $372 \mathrm{f}$ & & & $320 \mathrm{~g}$ & 10,5 \\
\hline \multicolumn{4}{|c|}{ Temperatura $\left({ }^{\circ} \mathrm{C}\right)$} & - \\
\hline 32 & & & 42 & - \\
\hline $333 j$ & & & $389 \mathrm{~h}$ & 10,5 \\
\hline
\end{tabular}

${ }^{*}$ Médias com mesmas letras em mesmo fator são semelhantes $(p>0,05)$

Tabela 5.3 - Médias e desvios padrões das forças máximas (g) correspondentes à interação ativação $x$ marca $x$ temperatura e valor crítico para contrastes *

\begin{tabular}{c|c|l|l|l}
\hline \multirow{2}{*}{ Marca } & Ativação $(\mathrm{mm})$ & \multicolumn{3}{|c}{ Temperatura $\left({ }^{\circ} \mathrm{C}\right)$} \\
\cline { 2 - 5 } & & \multicolumn{1}{|c}{32} & \multicolumn{1}{|c}{37} \\
\hline \multirow{5}{*}{ Forestadent } & 1 & $210(17)$ op & $214(13)$ op & $238(22) \mathrm{mnop}$ \\
& 2 & $278(20) \mathrm{Imn}$ & $296(29) \mathrm{Im}$ & $314(11) \mathrm{kl}$ \\
& 3 & $410(16) \mathrm{ghij}$ & $444(23) \mathrm{efg}$ & $466(24) \mathrm{cdefg}$ \\
& 4 & $494(29) \mathrm{cdef}$ & $524(23) \mathrm{bc}$ & $574(19) \mathrm{b}$ \\
\hline \multirow{3}{*}{ GAC } & 1 & $206(13) \mathrm{op}$ & $236(11) \mathrm{nop}$ & $232(8) \mathrm{nop}$ \\
& 2 & $256(21) \mathrm{Imno}$ & $314(30) \mathrm{kl}$ & $314(15) \mathrm{kl}$ \\
& 3 & $418(44) \mathrm{ghi}$ & $446(39) \mathrm{efg}$ & $500(34) \mathrm{cde}$ \\
& 4 & $514(40) \mathrm{cd}$ & $680(41) \mathrm{a}$ & $674(11) \mathrm{a}$ \\
\hline \multirow{3}{*}{ Morelli } & 1 & $182(13) \mathrm{p}$ & $190(19) \mathrm{p}$ & $212(27) \mathrm{op}$ \\
& 2 & $226(27) \mathrm{nop}$ & $264(15) \mathrm{Imn}$ & $282(19) \mathrm{Imn}$ \\
& 3 & $356(11) \mathrm{jk}$ & $378(28) \mathrm{ij}$ & $382(20) \mathrm{hij}$ \\
& 4 & $440(29) \mathrm{fgh}$ & $456(30) \mathrm{defg}$ & $478(13) \mathrm{cdef}$ \\
\hline
\end{tabular}

* Tuckey $(p=0,05)=59,2$. Médias com mesmas letras são semelhantes $(p>0,05)$ 
Tabela 5.4 - Análise de variância da diminuição da força com desativação de 0,20mm, a partir da ativação máxima

\begin{tabular}{l|c|c|r|c}
\hline Fonte de variação & G.L. & Quadrados médios & R.Q.M. & $\begin{array}{c}\text { Probabilidade } \\
\left(\mathrm{H}_{0}-\%\right)\end{array}$ \\
\hline Ativação (A) & 3 & $425.648,7500$ & 529,78 & 0,000 \\
Marca do fio (M) & 2 & $23.695,4492$ & 33,00 & 0,000 \\
Temperatura (T) & 2 & $11.500,5166$ & 16,02 & 0,001 \\
Interação A x M & 6 & $13.686,6025$ & 19,06 & 0,000 \\
Interação M x T & 4 & $2.715,6421$ & 3,78 & 0,617 \\
Interação A x T & 6 & $7.162,7808$ & 9,98 & 0,000 \\
Interação A x M x T & 12 & $2.052,2874$ & 2,86 & 0,176 \\
Resíduo & 144 & 718,0555 & - & - \\
Total & 179 & - & - & - \\
\hline
\end{tabular}

Tabela 5.5 - Médias da diminuição da força (g) dos fatores principais (ativação, marca e temperatura), com desativação de $0,20 \mathrm{~mm}$, a partir da ativação máxima e valores críticos para contrastes *

\begin{tabular}{|c|c|c|c|c|}
\hline \multicolumn{4}{|c|}{ Ativação (mm) } & \multirow{2}{*}{ Tuckey (5\%) } \\
\hline 1 & 2 & 3 & 4 & \\
\hline $52 \mathrm{c}$ & $66 \mathrm{c}$ & $148 \mathrm{~b}$ & $264 a$ & 14,7 \\
\hline \multicolumn{4}{|c|}{ Marca } & - \\
\hline Forestadent & & & Morelli & - \\
\hline $131 \mathrm{e}$ & & & $113 \mathrm{f}$ & 11,6 \\
\hline \multicolumn{4}{|c|}{ Temperatura $\left({ }^{\circ} \mathrm{C}\right)$} & - \\
\hline 32 & & & 42 & - \\
\hline $118 \mathrm{~h}$ & & & $145 q$ & 11,6 \\
\hline
\end{tabular}

* Médias com mesmas letras em mesmo fator são semelhantes $(p>0,05)$

Tabela 5.6 - Médias e desvios padrões da diminuição da força $(\mathrm{g})$ correspondentes à interação ativação $x$ marca $x$ temperatura, com desativação de $0,20 \mathrm{~mm}$, a partir da ativação máxima e valor crítico para contrastes*

\begin{tabular}{c|c|l|l|l}
\hline \multirow{2}{*}{ Marca } & Ativação $(\mathrm{mm})$ & \multicolumn{3}{|c}{ Temperatura $\left({ }^{\circ} \mathrm{C}\right)$} \\
\cline { 3 - 5 } & & \multicolumn{1}{|c}{32} & 37 & \multicolumn{1}{c}{42} \\
\hline \multirow{4}{*}{ Forestadent } & 1 & $054(11) \mathrm{jk}$ & $042(04) \mathrm{k}$ & $060(17) \mathrm{jk}$ \\
& 2 & $072(13) \mathrm{jjk}$ & $064(24) \mathrm{jk}$ & $074(11) \mathrm{jk}$ \\
& 3 & $144(21)$ efgh & $152(18)$ efg & $160(29)$ efg \\
& 4 & $206(29) \mathrm{cde}$ & $248(22) \mathrm{bc}$ & $296(13) \mathrm{b}$ \\
\hline \multirow{3}{*}{$\mathrm{GAC}$} & 1 & $058(18) \mathrm{jk}$ & $050(07) \mathrm{k}$ & $056(11) \mathrm{jk}$ \\
& 2 & $062(13) \mathrm{jk}$ & $080(21) \mathrm{hijk}$ & $056(14) \mathrm{jk}$ \\
& 3 & $130(29) \mathrm{fghi}$ & $154(25) \mathrm{efg}$ & $188(28) \mathrm{cdef}$ \\
& 4 & $250(89) \mathrm{bc}$ & $386(33) \mathrm{a}$ & $366(23) \mathrm{a}$ \\
\hline \multirow{3}{*}{ Morelli } & 1 & $040(00) \mathrm{k}$ & $046(05) \mathrm{k}$ & $062(13) \mathrm{jk}$ \\
& 2 & $066(23) \mathrm{jjk}$ & $054(09) \mathrm{jk}$ & $066(19) \mathrm{jk}$ \\
& 3 & $146(49) \mathrm{efg}$ & $146(21) \mathrm{efg}$ & $112(08) \mathrm{ghij}$ \\
& 4 & $182(23) \mathrm{def}$ & $198(58) \mathrm{cde}$ & $242(22) \mathrm{bcd}$ \\
\hline
\end{tabular}

\footnotetext{
${ }^{*}$ Tuckey $(p=0,05)=65,2$. Médias com mesmas letras são semelhantes $(p>0,05)$
} 
Tabela 5.7 - Análise de variância da diminuição da força com desativação de $0,70 \mathrm{~mm}$, a partir da ativação máxima (3 e 4mm)

\begin{tabular}{l|c|c|r|c}
\hline Fonte de variação & G.L. & Quadrados médios & R.Q.M. & $\begin{array}{c}\text { Probabilidade } \\
\left(\mathrm{H}_{0}-\%\right)\end{array}$ \\
\hline Ativação (A) & 1 & $658.776,8125$ & 697,94 & 0,000 \\
Marca do fio (M) & 2 & $88.314,6328$ & 93,56 & 0,000 \\
Temperatura (T) & 2 & $4.067,7000$ & 4,31 & 1,674 \\
Interação A x M & 2 & $35.014,2617$ & 37,10 & 0,000 \\
Interação M x T & 4 & $9.731,0840$ & 10,31 & 0,002 \\
Interação A x T & 2 & $9.040,3936$ & 9,58 & 0,040 \\
Interação A x M x T & 4 & $7.148,4688$ & 7,57 & 0,012 \\
Resíduo & 72 & 943,8889 & - & - \\
Total & 89 & - & - & \multicolumn{1}{|c}{-} \\
\hline
\end{tabular}

Tabela 5.8 - Médias da diminuição da força (g) dos fatores principais (ativação, marca e temperatura), com desativação de $0,70 \mathrm{~mm}$, a partir da ativação máxima (3 e $4 \mathrm{~mm})$ e valores críticos para contrastes *

\begin{tabular}{|c|c|c|c|}
\hline \multicolumn{3}{|c|}{ Ativação (mm) } & \multirow{2}{*}{ Tuckey (5\%) } \\
\hline 3 & & 4 & \\
\hline 265 & & 436 & $P<0,000$ \\
\hline \multicolumn{3}{|c|}{ Marca } & - \\
\hline Forestadent & GAC & Morelli & - \\
\hline $334 \mathrm{~b}$ & $412 \mathrm{a}$ & $307 c$ & 19,0 \\
\hline \multicolumn{3}{|c|}{ Temperatura $\left({ }^{\circ} \mathrm{C}\right)$} & - \\
\hline 32 & 37 & 42 & - \\
\hline $338 \mathrm{~b}$ & $353 a b$ & $361 \mathrm{a}$ & 19,0 \\
\hline
\end{tabular}

* Médias com mesmas letras em mesmo fator são semelhantes $(p>0,05)$

Tabela 5.9 - Médias e desvios padrões da diminuição da força $(\mathrm{g})$ correspondentes à interação ativação $\times$ marca $\times$ temperatura, com desativação de $0,70 \mathrm{~mm}$, a partir da ativação máxima ( 3 e $4 \mathrm{~mm})$ e valor crítico para contrastes*

\begin{tabular}{c|c|c|c|c}
\hline \multirow{2}{*}{ Marca } & Ativação $(\mathrm{mm})$ & \multicolumn{3}{|c}{ Temperatura $\left({ }^{\circ} \mathrm{C}\right)$} \\
\cline { 3 - 5 } & & 32 & 37 & 42 \\
\hline \multirow{2}{*}{ Forestadent } & 3 & $274(17)$ ef & $266(19)$ ef & $262(26)$ ef \\
& 4 & $390(21) \mathrm{bc}$ & $390(25) \mathrm{bc}$ & $420(07) \mathrm{bc}$ \\
\hline \multirow{2}{*}{$\mathrm{GAC}$} & 3 & $284(43) \mathrm{ef}$ & $266(32) \mathrm{ef}$ & $310(37) \mathrm{de}$ \\
& 4 & $434(59) \mathrm{b}$ & $602(40) \mathrm{a}$ & $574(19) \mathrm{a}$ \\
\hline \multirow{2}{*}{ Morelli } & 3 & $260(16) \mathrm{ef}$ & $234(30) \mathrm{f}$ & $232(20) \mathrm{f}$ \\
& 4 & $388(29) \mathrm{bc}$ & $360(44) \mathrm{cd}$ & $370(22) \mathrm{bcd}$ \\
\hline
\end{tabular}

* Tuckey $(p=0,05)=70,3$. Médias com mesmas letras são semelhantes $(p>0,05)$ 
Tabela 5.10 - Análise de variância das extensões dos platôs com ativação máxima de 3 e $4 \mathrm{~mm}$

\begin{tabular}{l|c|c|r|c}
\hline Fonte de variação & G.L. & Quadrados médios & R.Q.M. & $\begin{array}{c}\text { Probabilidade } \\
\left(\mathrm{H}_{0}-\%\right)\end{array}$ \\
\hline Ativação (A) & 1 & 32,4001 & 483,18 & 0,000 \\
Marca do fio (M) & 2 & 3,2761 & 48,86 & 0,000 \\
Temperatura (T) & 2 & 1,0511 & 15,67 & 0,003 \\
Interação A x M & 2 & 0,1293 & 1,93 & 15,089 \\
Interação M x T & 4 & 0,3230 & 4,82 & 0,202 \\
Interação A x T & 2 & 0,6763 & 10,09 & 0,031 \\
Interação A x M x T & 4 & 0,1937 & 2,89 & 2,773 \\
Resíduo & 72 & 0,0671 & - & - \\
Total & 89 & - & - & \multicolumn{1}{|c}{-} \\
\hline
\end{tabular}

Tabela 5.11 - Médias das extensões dos platôs $(\mathrm{mm})$ dos fatores principais (ativação, marca e temperatura), com ativação máxima de 3 e $4 \mathrm{~mm}$ e valores críticos para contrastes *

\begin{tabular}{|c|c|c|c|}
\hline \multicolumn{3}{|c|}{ Ativacão (mm) } & \multirow{2}{*}{ Tuckey (5\%) } \\
\hline 3 & & 4 & \\
\hline 1,00 & & 2,20 & $P<0,000$ \\
\hline \multicolumn{3}{|c|}{ Marca } & - \\
\hline Forestadent & GAC & Morelli & - \\
\hline $1,76 \mathrm{a}$ & $1,82 \mathrm{a}$ & $1,22 b$ & 0,160 \\
\hline \multicolumn{3}{|c|}{ Temperatura $\left({ }^{\circ} \mathrm{C}\right)$} & - \\
\hline 32 & 37 & 42 & - \\
\hline $1,39 d$ & $1,74 \mathrm{c}$ & $1,68 \mathrm{c}$ & 0,160 \\
\hline
\end{tabular}

* Médias com mesmas letras em mesmo fator são semelhantes $(p>0,05)$

Tabela 5.12 - Médias e desvios padrões dos platôs $(\mathrm{mm})$, correspondentes à interação ativação $\mathrm{x}$ marca $x$ temperatura, com ativação de 3 e $4 \mathrm{~mm}$, médias das ativações no início e final dos platôs e valor crítico para contrastes*

\begin{tabular}{|c|c|c|c|c|c|c|c|}
\hline \multirow{2}{*}{$\begin{array}{c}\text { Temp } \\
\left({ }^{\circ} \mathrm{C}\right)\end{array}$} & \multirow{2}{*}{ Marca } & \multicolumn{3}{|c|}{ Platô/ativação 3mm } & \multicolumn{3}{|c|}{ Platô/ativação $4 \mathrm{~mm}$} \\
\hline & & Extensão & Início & Final & Extensão & Início & Final \\
\hline \multirow{3}{*}{32} & Forestadent & $1,08(0,16) b c$ & 2,20 & 1,12 & $2,36(0,18) a$ & 3,32 & 0,96 \\
\hline & GAC & $1,22(0,08) b$ & 2,26 & 1,04 & $2,10(0,22) a$ & 3,34 & 1,24 \\
\hline & Morelli & $0,58(0,13) c$ & 2,22 & 1,64 & $0,98(0,82) b c$ & 3,26 & 2,28 \\
\hline \multirow{3}{*}{37} & Forestadent & $1,16(0,09) b c$ & 2,16 & 1,00 & $2,50(0,12) a$ & 3,34 & 0,84 \\
\hline & GAC & $1,22(0,04) b$ & 2,20 & 0,98 & $2,58(0,08) a$ & 3,26 & 0,68 \\
\hline & Morelli & $0,76(0,31) b c$ & 1,98 & 1,22 & $2,20(0,23) a$ & 3,10 & 0,90 \\
\hline \multirow{3}{*}{42} & Forestadent & $1,08(0,13) b c$ & 2,16 & 1,08 & $2,38(0,16) a$ & 3,30 & 0,92 \\
\hline & GAC & $1,16(0,05) b c$ & 2,22 & 1,06 & $2,64(0,13) a$ & 3,38 & 0,74 \\
\hline & Morelli & $0,74(0,13) b c$ & 2,14 & 1,40 & $2,06(0,36) \mathrm{a}$ & 3,36 & 1,30 \\
\hline
\end{tabular}

Tuckey $(p=0,05)=0,593$. Médias com mesmas letras são semelhantes $(p>0,005)$ 
Tabela 5.13 - Análise de variância das médias ponderadas das forças nos platôs com ativação máxima de 3 e $4 \mathrm{~mm}$

\begin{tabular}{l|c|c|r|c}
\hline Fonte de variação & G.L. & Quadrados médios & R.Q.M. & $\begin{array}{c}\text { Probabilidade } \\
\left(\mathrm{H}_{0}-\%\right)\end{array}$ \\
\hline Ativação (A) & 1 & $18.748,9277$ & 149,96 & 0,000 \\
Marca do fio (M) & 2 & $28.777,5742$ & 230,17 & 0,000 \\
Temperatura (T) & 2 & $21.575,4414$ & 172,57 & 0,000 \\
Interação A x M & 2 & 919,6036 & 7,36 & 0,160 \\
Interação M x T & 4 & 206,9547 & 1,66 & 16,881 \\
Interação A x T & 2 & 49,0697 & 0,39 & 68,238 \\
Interação A x M x T & 4 & 21,9064 & 0,18 & 94,821 \\
Resíduo & 72 & 125,0278 & - & - \\
Total & 89 & - & - & - \\
\hline
\end{tabular}

Tabela 5.14 - Médias ponderadas das forças (g) nos platôs dos fatores principais (ativação, marca e temperatura), com ativação máxima de 3 e $4 \mathrm{~mm}$ e valores críticos para contrastes *

\begin{tabular}{|c|c|c|c|}
\hline \multicolumn{3}{|c|}{ Ativação $(\mathrm{mm})$} & \multirow{2}{*}{ Tuckey (5\%) } \\
\hline 3 & & 4 & \\
\hline 132 & & 103 & $P<0,000$ \\
\hline \multicolumn{3}{|c|}{ Marca } & - \\
\hline Forestadent & GAC & Morelli & - \\
\hline $140 \mathrm{a}$ & $131 \mathrm{~b}$ & $82 \mathrm{c}$ & 6,9 \\
\hline \multicolumn{3}{|c|}{ Temperatura $\left({ }^{\circ} \mathrm{C}\right)$} & - \\
\hline 32 & 37 & 42 & - \\
\hline $91 \mathrm{f}$ & $117 \mathrm{e}$ & $145 d$ & 6,9 \\
\hline
\end{tabular}

* Médias com mesmas letras em mesmo fator são semelhantes $(p>0,05)$

Tabela 5.15 - Médias ponderadas e desvios padrões das forças $(\mathrm{g})$ nos platôs, correspondentes à interação ativação $x$ marca $x$ temperatura, com ativação de 3 e $4 \mathrm{~mm}$ e valor crítico para contrastes*

\begin{tabular}{c|c|c|c}
\hline Temp. & \multirow{2}{*}{$\begin{array}{c}\text { Marca } \\
\left({ }^{\circ} \mathrm{C}\right)\end{array}$} & \multicolumn{2}{|c}{ Ativação (mm) } \\
\cline { 3 - 4 } 32 & Forestadent & $116(10) \mathrm{defg}$ & 4 \\
& GAC & $125(05) \mathrm{cde}$ & $099(23) \mathrm{fghi}$ \\
& Morelli & $076(12) \mathrm{ij}$ & $087(14) \mathrm{hij}$ \\
& Forestadent & $151(05) \mathrm{b}$ & $043(10) \mathrm{k}$ \\
\hline \multirow{3}{*}{37} & GAC & $147(07) \mathrm{bc}$ & $137(07) \mathrm{bcd}$ \\
& Morelli & $093(16) \mathrm{ghi}$ & $111(06) \mathrm{efgh}$ \\
& Forestadent & $178(05) \mathrm{a}$ & $064(08) \mathrm{jk}$ \\
\hline \multirow{3}{*}{42} & GAC & $180(11) \mathrm{a}$ & $157(18) \mathrm{ab}$ \\
& Morelli & $123(08) \mathrm{cdef}$ & $136(07) \mathrm{bcd}$ \\
& &
\end{tabular}

* Tuckey $(p=0,05)=25,6$. Médias com mesmas letras são semelhantes $(p>0,05)$ 
Tabela 5.16 - Análise de variância da desativação até registrar a força de $50 \mathrm{~g}$, a partir de 0,80 e $1,80 \mathrm{~mm}$ (respectivamente 1 e $2 \mathrm{~mm}$ de ativação) e a partir do final do platô (com 3 e $4 \mathrm{~mm}$ de ativação)

\begin{tabular}{l|c|c|r|c}
\hline Fonte de variação & G.L. & Quadrados médios & R.Q.M. & $\begin{array}{c}\text { Probabilidade } \\
\left(\mathrm{H}_{0}-\%\right)\end{array}$ \\
\hline Ativação (A) & 3 & 10,3655 & 495,08 & 0,000 \\
Marca do fio (M) & 2 & 0,4023 & 19,22 & 0,000 \\
Temperatura (T) & 2 & 0,6133 & 29,30 & 0,000 \\
Interação A x M & 6 & 0,0926 & 4,42 & 0,061 \\
Interação M x T & 4 & 0,1576 & 7,53 & 0,007 \\
Interação A x T & 6 & 0,1117 & 5,34 & 0,015 \\
Interação A x M x T & 12 & 0,0747 & 3,57 & 0,024 \\
Resíduo & 144 & 0,0209 & - & - \\
Total & 179 & - & - & - \\
\hline
\end{tabular}

Tabela 5.17 - Médias $(\mathrm{mm})$ para desativar até $50 \mathrm{~g}$, a partir de 0,80 e 1,80mm (respectivamente 1 e $2 \mathrm{~mm}$ de ativação) e a partir do final do platô (3 e $4 \mathrm{~mm}$ de ativação), correspondentes aos fatores principais (ativação, marca e temperatura), e valores críticos para contrastes*

\begin{tabular}{|c|c|c|c|c|}
\hline \multicolumn{4}{|c|}{ Ativação (mm) } & \multirow{2}{*}{ Tuckey (5\%) } \\
\hline 1 & 2 & 3 & 4 & \\
\hline $0,40 \mathrm{c}$ & $1,27 \mathrm{a}$ & $0,50 \mathrm{~b}$ & $0,15 d$ & 0,079 \\
\hline \multicolumn{4}{|c|}{ Marca } & - \\
\hline Forestadent & & & Morelli & - \\
\hline $0,67 \mathrm{e}$ & & & $0,54 \mathrm{f}$ & 0,063 \\
\hline \multicolumn{4}{|c|}{ Temperatura $\left({ }^{\circ} \mathrm{C}\right)$} & - \\
\hline 32 & \multicolumn{2}{|c|}{37} & 42 & - \\
\hline $0,46 \mathrm{~h}$ & \multicolumn{2}{|c|}{$0,65 g$} & $0,62 \mathrm{~g}$ & 0,063 \\
\hline
\end{tabular}

* Médias com mesmas letras em mesmo fator são semelhantes $(p>0,05)$ 
Tabela 5.18 - Médias e desvios padrões $(\mathrm{mm})$ para desativar até $50 \mathrm{~g}$ a partir de 0,80 e 1,80 $\mathrm{mm}$ (respectivamente 1 e $2 \mathrm{~mm}$ de ativação) e a partir do final do platô ( 3 e $4 \mathrm{~mm}$ de ativação) correspondentes à interação ativação x marca $\mathrm{x}$ temperatura, e valor crítico para contrastes*

\begin{tabular}{|c|c|c|c|c|}
\hline \multirow{2}{*}{ Marca } & \multirow{2}{*}{$\begin{array}{l}\text { Ativação } \\
\text { (mm) }\end{array}$} & \multicolumn{3}{|c|}{ Temperatura $\left({ }^{\circ} \mathrm{C}\right)$} \\
\hline & & 32 & 37 & 42 \\
\hline \multirow{4}{*}{ Forestadent } & 1 & $0,39(0,05)$ defg & $0,50(0,07) \mathrm{de}$ & $0,40(0,08)$ defg \\
\hline & 2 & $1,27(0,04) a b$ & $1,41(0,02) a$ & $1,32(0,10) a b$ \\
\hline & 3 & $0,45(0,09)$ def & $0,69(0,17) \mathrm{cd}$ & $0,58(0,14) d$ \\
\hline & 4 & $0,21(0,16)$ efg & $0,49(0,22) \mathrm{de}$ & $0,36(0,07)$ defg \\
\hline \multirow{4}{*}{ GAC } & 1 & $0,35(0,14)$ defg & $0,40(0,07)$ defg & $0,37(0,04)$ defg \\
\hline & 2 & $1,19(0,07) a b$ & $1,36(0,11) \mathrm{a}$ & $1,21(0,16) a b$ \\
\hline & 3 & $0,34(0,10)$ defg & $0,42(0,12)$ def & $0,40(0,11)$ defg \\
\hline & 4 & $0,06(0,07) \mathrm{g}$ & $0,06(0,03) \mathrm{g}$ & $0,11(0,04) \mathrm{fg}$ \\
\hline \multirow{4}{*}{ Morelli } & 1 & $0,38(0,03)$ defg & $0,46(0,04)$ def & $0,34(0,14)$ defg \\
\hline & 2 & $1,00(0,09) b c$ & $1,36(0,07) \mathrm{a}$ & $1,27(0,15) a b$ \\
\hline & 3 & $0,40(0,22)$ defg & $0,60(0,40) d$ & $0,60(0,07) d$ \\
\hline & 4 & $-0,48(0,26) h$ & $0,08(0,15) \mathrm{q}$ & $0,49(0,35) \mathrm{de}$ \\
\hline
\end{tabular}

* Tuckey $(p=0,05)=0,352$. Médias com mesmas letras são semelhantes $(p>0,05)$

Tabela 5.19 - Análise de variância da força ao iniciar a desativação até $50 \mathrm{~g}$, em 0,80 e 1,80mm (respectivamente 1 e $2 \mathrm{~mm}$ ) de ativação e a partir do final do platô (com 3 e $4 \mathrm{~mm}$ de ativação)

\begin{tabular}{l|c|c|r|c}
\hline Fonte de variação & G.L. & Quadrados médios & R.Q.M. & $\begin{array}{c}\text { Probabilidade } \\
\left(\mathrm{H}_{\mathrm{o}}-\%\right)\end{array}$ \\
\hline Ativação (A) & 3 & $151.048,5469$ & 662,33 & 0,000 \\
Marca do fio (M) & 2 & $27.800,7832$ & 121,90 & 0,000 \\
Temperatura (T) & 2 & $28.170,5176$ & 123,52 & 0,000 \\
Interação A x M & 6 & $2.098,3018$ & 9,20 & 0,000 \\
Interação M x T & 4 & 25,4746 & 0,11 & 97,524 \\
Interação A x T & 6 & $1.241,7681$ & 5,45 & 0,013 \\
Interação A x M x T & 12 & 497,8271 & 2,18 & 1,533 \\
Resíduo & 144 & 228,0556 & - & - \\
Total & 179 & - & - & - \\
\hline
\end{tabular}


Tabela 5.20 - Médias das forças (g) ao iniciar a desativação até $50 \mathrm{~g}$, em 0,80 e 1,80mm (respectivamente 1 e $2 \mathrm{~mm}$ de ativação) e no final do platô ( 3 e $4 \mathrm{~mm}$ de ativação), correspondentes aos fatores principais (ativação, marca e temperatura), e valores críticos para contrastes *

\begin{tabular}{|c|c|c|c|c|}
\hline \multicolumn{4}{|c|}{ Ativação (mm) } & \multirow[t]{2}{*}{ Tuckey (5\%) } \\
\hline 1 & 2 & 3 & 4 & \\
\hline $161 \mathrm{~b}$ & $217 a$ & $122 \mathrm{c}$ & $81 \mathrm{~d}$ & 8,3 \\
\hline \multicolumn{4}{|c|}{ Marca } & - \\
\hline Forestadent & & & Morelli & - \\
\hline $163 \mathrm{e}$ & & & $122 \mathrm{~g}$ & 6,5 \\
\hline \multicolumn{4}{|c|}{ Temperatura $\left({ }^{\circ} \mathrm{C}\right)$} & - \\
\hline 32 & & & 42 & - \\
\hline $123 j$ & & & $166 \mathrm{~h}$ & 6,5 \\
\hline
\end{tabular}

* Médias com mesmas letras em mesmo fator são semelhantes $(p>0,05)$

Tabela 5.21 - Médias das forças e desvios padrões (g) ao iniciar a desativação até $50 \mathrm{~g} \mathrm{em} 0,80 \mathrm{e}$ $1,80 \mathrm{~mm}$ (respectivamente 1 e $2 \mathrm{~mm}$ de ativação) e no final do platô ( 3 e $4 \mathrm{~mm}$ de desativação), correspondentes à interações ativação $x$ marca $x$ temperatura, e valor crítico para contrastes*

\begin{tabular}{|c|c|c|c|c|}
\hline \multirow{2}{*}{ Marca } & \multirow{2}{*}{$\begin{array}{c}\text { Ativação } \\
(\mathrm{mm})\end{array}$} & \multicolumn{3}{|c|}{ Temperatura $\left({ }^{\circ} \mathrm{C}\right)$} \\
\hline & & 32 & 37 & 42 \\
\hline \multirow{4}{*}{ Forestadent } & 1 & 156 (11) hij & 172 (13) fghi & 178 (27) efghi \\
\hline & 2 & $206(09)$ cdef & 232 (13) abc & $246(05) \mathrm{ab}$ \\
\hline & 3 & $110(00) \mathrm{Im}$ & 144 (05) ijkl & 172 (04) fghij \\
\hline & 4 & $084(24) \mathrm{mn}$ & $118(04) \mathrm{klm}$ & $138(28) \mathrm{jkl}$ \\
\hline \multirow{4}{*}{ GAC } & 1 & 148 (26) ijk & 186 (15) defgh & 176 (11) efghi \\
\hline & 2 & 194 (09) defg & 234 (17) abc & $258(11) \mathrm{a}$ \\
\hline & 3 & $110(07) \mathrm{Im}$ & 136 (09) jkl & 164 (18)ghij \\
\hline & 4 & $066(22) n$ & $068(08) n$ & $086(09) \mathrm{mn}$ \\
\hline \multirow{4}{*}{ Morelli } & 1 & 142 (13) ijkl & 144 (18) ijkl & 150 (38) hijk \\
\hline & 2 & 160 (10)ghij & 210 (10) bcde & 216 (05) bcd \\
\hline & 3 & $066(11) n$ & 084 (15) mn & $114(09) \mathrm{klm}$ \\
\hline & 4 & $028(04) 0$ & 056 (11) no & $088(11) \mathrm{mn}$ \\
\hline
\end{tabular}

\footnotetext{
${ }^{*}$ Tuckey $(p=0,05)=36,8$. Médias com mesmas letras são semelhantes $(p>0,05)$
} 
Tabela 5.22 - Análise de variância do afastamento da origem ao registrar $50 \mathrm{~g}$ de força na desativação

\begin{tabular}{l|c|c|r|c}
\hline \multicolumn{1}{c|}{ Fonte de variação } & G.L. & Quadrados médios & R.Q.M. & $\begin{array}{c}\text { Probabilidade } \\
\left(\mathrm{H}_{0}-\%\right)\end{array}$ \\
\hline Ativação (A) & 3 & 2,4427 & 62,51 & 0,000 \\
Marca do fio (M) & 2 & 1,9437 & 49,74 & 0,000 \\
Temperatura (T) & 2 & 2,4078 & 61,62 & 0,000 \\
Interação A x M & 6 & 0,5898 & 15,09 & 0,000 \\
Interação M x T & 4 & 0,6987 & 17,88 & 0,000 \\
Interação A x T & 6 & 0,6830 & 17,48 & 0,000 \\
Interação A x M x T & 12 & 0,2824 & 7,23 & 0,000 \\
Resíduo & 144 & 0,0391 & - & - \\
Total & 179 & - & - & - \\
\hline
\end{tabular}

Tabela 5.23 - Médias dos afastamentos $(\mathrm{mm})$ da origem, ao registrar $50 \mathrm{~g}$ de força, correspondentes aos fatores principais (ativação, marca e temperatura), e valor crítico para contrastes*

\begin{tabular}{|c|c|c|c|c|}
\hline \multicolumn{4}{|c|}{ Ativação (mm) } & \multirow[t]{2}{*}{ Tuckey (5\%) } \\
\hline 1 & 2 & 3 & 4 & \\
\hline $0,40 \mathrm{~d}$ & $0,53 \mathrm{c}$ & $0,70 \mathrm{~b}$ & $0,94 \mathrm{a}$ & 0,108 \\
\hline \multicolumn{4}{|c|}{ Marca } & - \\
\hline Forestadent & & & Morelli & - \\
\hline $0,49 \mathrm{~g}$ & & & $0,84 \mathrm{e}$ & 0,085 \\
\hline \multicolumn{4}{|c|}{ Temperatura $\left({ }^{\circ} \mathrm{C}\right)$} & - \\
\hline 32 & & & 42 & - \\
\hline $0,87 \mathrm{~h}$ & & & $0,57 \mathrm{i}$ & 0,085 \\
\hline
\end{tabular}

* Médias com mesmas letras em mesmo fator são semelhantes $(p>0,05)$

Tabela 5.24 - Médias e desvios padrões dos afastamentos $(\mathrm{mm})$ da origem ao atingir $50 \mathrm{~g}$ de força, correspondentes à interação ativação $\mathrm{x}$ marca $\mathrm{x}$ temperatura, e valor crítico para contrastes ${ }^{\star}$

\begin{tabular}{c|c|c|c|c}
\hline \multirow{2}{*}{ Marca } & Ativação & \multicolumn{3}{|c}{ Temperatura $\left({ }^{\circ} \mathrm{C}\right)$} \\
\cline { 3 - 5 } & $(\mathrm{mm})$ & 32 & 37 & 42 \\
\hline \multirow{5}{*}{ Forestadent } & 1 & $0,41(0,05) \mathrm{de}$ & $0,30(0,07) \mathrm{e}$ & $0,40(0,08) \mathrm{de}$ \\
& 2 & $0,53(0,04) \mathrm{de}$ & $0,39(0,02) \mathrm{de}$ & $0,48(0,10) \mathrm{de}$ \\
& 3 & $0,67(0,14) \mathrm{cde}$ & $0,43(0,07) \mathrm{de}$ & $0,50(0,09) \mathrm{de}$ \\
& 4 & $0,75(0,24) \mathrm{cde}$ & $0,45(0,08) \mathrm{de}$ & $0,56(0,09) \mathrm{de}$ \\
\hline \multirow{4}{*}{$\mathrm{GAC}$} & 1 & $0,45(0,14) \mathrm{de}$ & $0,40(0,07) \mathrm{de}$ & $0,43(0,04) \mathrm{de}$ \\
& 2 & $0,61(0,07) \mathrm{de}$ & $0,44(0,11) \mathrm{de}$ & $0,59(0,16) \mathrm{de}$ \\
& 3 & $0,66(0,10) \mathrm{cde}$ & $0,60(0,05) \mathrm{de}$ & $0,66(0,08) \mathrm{cde}$ \\
& 4 & $1,10(0,26) \mathrm{bc}$ & $0,64(0,08) \mathrm{cde}$ & $0,63(0,11) \mathrm{cde}$ \\
\hline \multirow{4}{*}{ Morelli } & 1 & $0,42(0,03) \mathrm{de}$ & $0,34(0,04) \mathrm{de}$ & $0,46(0,14) \mathrm{de}$ \\
& 2 & $0,80(0,09) \mathrm{cd}$ & $0,44(0,07) \mathrm{de}$ & $0,53(0,15) \mathrm{de}$ \\
& 3 & $1,32(0,08) \mathrm{b}$ & $0,62(0,23) \mathrm{cde}$ & $0,80(0,10) \mathrm{cd}$ \\
& 4 & $2,72(0,97) \mathrm{a}$ & $0,82(0,16) \mathrm{cd}$ & $0,81(0,13) \mathrm{cd}$ \\
\hline
\end{tabular}

${ }^{*}$ Tuckey $(p=0,05)=0,481$. Médias com mesmas letras são semelhantes $(p>0,05)$ 
Tabela 5.25 - Análise de variância da deformação permanente ao alcançar força zero na desativação

\begin{tabular}{l|c|c|r|c}
\hline Fonte de variação & G.L. & Quadrados médios & R.Q.M. & $\begin{array}{c}\text { Probabilidade } \\
\left(\mathrm{H}_{0}-\%\right)\end{array}$ \\
\hline Ativação (A) & 3 & 0,6497 & 35,49 & 0,000 \\
Marca do fio (M) & 2 & 0,5309 & 29,00 & 0,000 \\
Temperatura (T) & 2 & 0,8057 & 44,01 & 0,000 \\
Interação A x M & 6 & 0,0430 & 2,35 & 3,348 \\
Interação M x T & 4 & 0,0986 & 5,39 & 0,070 \\
Interação A x T & 6 & 0,0948 & 5,18 & 0,019 \\
Interação A x M x T & 12 & 0,0330 & 1,80 & 5,236 \\
Resíduo & 144 & 0,0183 & - & - \\
Total & 179 & - & - & \multicolumn{1}{|c}{} \\
\hline
\end{tabular}

Tabela 5.26 - Médias da deformação permanente $(\mathrm{mm})$ ao alcançar a força zero dos fatores principais (ativação, marca e temperatura), e valores críticos para contrastes*

\begin{tabular}{|c|c|c|c|c|}
\hline \multicolumn{4}{|c|}{ Ativação (mm) } & \multirow[t]{2}{*}{ Tuckey (5\%) } \\
\hline 1 & 2 & 3 & 4 & \\
\hline $0,20 \mathrm{~d}$ & $0,30 \mathrm{c}$ & $0,38 \mathrm{~b}$ & $0,48 \mathrm{a}$ & 0,074 \\
\hline \multicolumn{4}{|c|}{ Marca } & - \\
\hline Forestadent & & & Morelli & - \\
\hline $0,23 \mathrm{f}$ & & & $0,38 \mathrm{e}$ & 0,059 \\
\hline \multicolumn{4}{|c|}{ Temperatura $\left({ }^{\circ} \mathrm{C}\right)$} & - \\
\hline 32 & & & 42 & - \\
\hline $0,46 \mathrm{~g}$ & & & $0,35 \mathrm{~h}$ & 0,059 \\
\hline
\end{tabular}

* Médias com mesmas letras em mesmo fator são semelhantes $(p>0,05)$ 
Tabela 5.27 - Médias e desvios padrões da deformação permanente $(\mathrm{mm})$ ao alcançar a força zero na desativação, correspondentes à interação ativação $x$ marca $x$ temperatura, e valor crítico para contrastes*

\begin{tabular}{|c|c|c|c|c|}
\hline \multirow{2}{*}{ Marca } & \multirow{2}{*}{$\begin{array}{l}\text { Ativação } \\
(\mathrm{mm})\end{array}$} & \multicolumn{3}{|c|}{ Temperatura $\left({ }^{\circ} \mathrm{C}\right)$} \\
\hline & & 32 & 37 & 42 \\
\hline \multirow{4}{*}{ Forestadent } & 1 & $0,18(0,08)$ def & $0,10(0,07) \mathrm{f}$ & $0,18(0,08)$ def \\
\hline & 2 & $0,28(0,08)$ def & $0,16(0,05)$ ef & $0,26(0,09)$ def \\
\hline & 3 & $0,34(0,11)$ def & $0,14(0,05)$ ef & $0,24(0,18)$ def \\
\hline & 4 & $0,40(0,22)$ cdef & $0,18(0,08)$ def & $0,34(0,11)$ def \\
\hline \multirow{4}{*}{ GAC } & 1 & $0,28(0,15)$ def & $0,22(0,08)$ def & $0,24(0,05)$ def \\
\hline & 2 & $0,40(0,12)$ cdef & $0,22(0,13)$ def & $0,44(0,18)$ cde \\
\hline & 3 & $0,44(0,11)$ cde & $0,42(0,04)$ cdef & $0,50(0,10) \mathrm{bcd}$ \\
\hline & 4 & $0,80(0,32) a b$ & $0,46(0,09) \mathrm{cde}$ & $0,46(0,09) \mathrm{cde}$ \\
\hline \multirow{4}{*}{ Morelli } & 1 & $0,20(0,07)$ def & $0,10(0,00) f$ & $0,28(0,15)$ def \\
\hline & 2 & $0,50(0,07) \mathrm{bcd}$ & $0,18(0,08)$ def & $0,30(0,14)$ def \\
\hline & 3 & $0,68(0,13) a b c$ & $0,20(0,12)$ def & $0,46(0,15)$ cde \\
\hline & 4 & $0,96(0,27) \mathrm{a}$ & $0,30(0,22)$ def & $0,44(0,15)$ cde \\
\hline
\end{tabular}

${ }^{*}$ Tuckey $(p=0,05)=0,329$. Médias com mesmas letras são semelhantes $(p>0,05)$ 


\section{DISCUSSÃO}

A discussão será feita por grandeza avaliada, como no capítulo de Resultados. No entanto, nos casos em que for pertinente e houver interesse, na discussão, podem ser abordadas várias grandezas.

\subsection{Forças máximas nas diversas ativações}

Os resultados das forças máximas alcançadas nas diversas ativações (Tabelas 5.1 a 5.3 e Figuras 5.1 a 5.4 e 4.6 , letra A) mostraram que com os fios .016" de níquettitânio com as propriedades de superelasticidade, as forças necessárias para a ativação foram relativamente pequenas. Mesmo com deflexão de $4 \mathrm{~mm}$ alcançou $680 \mathrm{~g}$ no máximo, com o fio da marca GAC na temperatura de $37^{\circ} \mathrm{C}$. Geralmente os valores ficaram abaixo de $500 \mathrm{~g}$.

Clinicamente, em princípio parece não ser uma força exagerada, se comparada com fios tradicionais como de aço inoxidável ou de ligas a base de níquel, cromo e cobalto, que apresentam uma rigidez, para condições semelhantes, bem maior, pelo fato do módulo de elasticidade ser algumas vezes maior. Também, uma ativação de $4 \mathrm{~mm}$, seria pouco comum encontrar um desnivelamento dessa magnitude. O fato talvez explique a dificuldade de encontrar dados na literatura. Mohlin et al. (1991), com ativação de $4 \mathrm{~mm}$ apresentaram um valor não muito diferente $(420 \mathrm{~g})$, também com fio $.016 "$. Entretanto comparando a força de cerca de $600 \mathrm{~g}$ com fios de alta rigidez, o valor não é grande. Assim, Lino (1970) encontrou 
com alças de retração tipo clínica, $1200 \mathrm{~g}$, para uma ativação de $2 \mathrm{~mm}$ apenas e, nas condições, já tinha sido alcançado o limite de proporcionalidade e uma ativação além desse valor $(2 \mathrm{~mm})$ já teria ultrapassado o limite de escoamento, ocorrendo deformação permanente.

Em outros trabalhos (MIURA et al., 1986; MIURA, MOGI e OHURA, 1988; MIURA, MOGI e OKAMOTO, 1990), quer em ensaios de deflexão em 3 pontos, quer em dobramentos angulares, sempre os fios de aço inoxidável e a base de Ni-Cr-Co requeriam força bem maior para as mesmas ativações.

A força máxima necessária para a ativação de $3 \mathrm{~mm}$, em geral, foi de 80 a $100 \mathrm{~g}$ menor do que na de $4 \mathrm{~mm}$. O valor médio foi de $422 \mathrm{~g}$. Esse valor é comparável com os resultados de lijima et al. (2002b), com ativação de $3 \mathrm{~mm}$ e em ensaio a $37^{\circ} \mathrm{C}$ (fio $.016 " \times \cdot 022^{\prime \prime}$ ). Com $A_{f}$ da liga a $16^{\circ} \mathrm{C}$, encontraram uma força máxima de cerca de $400 \mathrm{~g}$, com $\mathrm{A}_{f}$ a $22^{\circ} \mathrm{C}$, cerca de $320 \mathrm{~g}$ e com $\mathrm{Ar} 37^{\circ} \mathrm{C}$, cerca de 220g. Por esses resultados pode-se verificar o quanto é crítica a natureza da liga, onde pode influenciar a composição e tratamento térmicos e de trabalho mecânico (encruamento).

A ativação de até $2 \mathrm{~mm}$ necessitou uma força média de $283 \mathrm{~g}$, cerca de $140 \mathrm{~g}$ menos do que a de $3 \mathrm{~mm}$. Ativações de até $2 \mathrm{~mm}$ são encontradas na literatura com freqüência razoável, mesmo mudando as dimensões dos fios e, às vezes, apresentados tratamentos diversos dos mesmos. Miura et al. (1986) testaram um fio .016" de NiTi Japonês e o submeteram a diversos tratamentos térmicos antes dos ensaios de deflexão, variando o tempo de 5 a 120 min. A temperatura controle (sem tratamento térmico) para a deflexão de $2 \mathrm{~mm}$ necessitou cerca de $650 \mathrm{~g}$; com tratamento térmico a $400^{\circ} \mathrm{C}$, a força necessária chegou em torno de $590 \mathrm{~g}$; a $500^{\circ} \mathrm{C}$, os valores variaram de 570 a $450 \mathrm{~g}$ (quanto maior o tempo, menor a força); a $600^{\circ} \mathrm{C}$ 
os valores variaram de 550 a 340g. Em outro trabalho, Miura, Mogi e Ohura (1988) encontraram valores em torno de 400 a 650g. Ainda Miura, Mogi e Okamoto (1990), com fio Sentalloy retangular .018" x .025" e 2 mm de deflexão, encontraram força de cerca de 750g. Mohlin et al. (1991) com fio Chinês TiNi .016" apresentaram valor em torno de 350g. Gurgel et al. (2001b) com fio .017" x .025" e 2 mm de deflexão encontraram valores de força de 1600 a $2000 \mathrm{~g}$, conforme o fio. Ainda Yanuru et al. (2003), com fios .016" x .022", em ensaios até $2 \mathrm{~mm}$ de deflexão em temperaturas diferentes, encontraram valores nos intervalos: de 400 a 1300g, conforme marca de fio e temperatura de ensaio.

A deflexão até $1 \mathrm{~mm}$, apresentou o menor valor médio (213g). Para esta ativação não foram encontradas diferenças significantes entre marcas e nem entre temperaturas (Tabela 5.3). Clinicamente esta força não é alta, quando comparada com a de outros materiais. Lino (1970), com fio retangular .021" x .025" de liga a base de níquetcromo, pesquisando alças de retração e não de flexão, como na presente investigação, com $1 \mathrm{~mm}$ de ativação, a força correspondente era de $600 \mathrm{~g}$. Miura et al. (1986), com fio .016" de liga de NiTi Japonesa, correspondente à ativação de $1 \mathrm{~mm}$, encontraram valores de 250 a $500 \mathrm{~g}$, conforme o tratamento térmico, quanto à temperatura e tempo, realizado com o material antes dos ensaios. Ainda com $1 \mathrm{~mm}$ de ativação e dimensões semelhantes, Miura, Mogi e Okamoto (1990) encontraram para o aço inoxidável 3000g e para o NiTi (GAC, Neo Sentalloy F100) cerca de $500 \mathrm{~g}$. Com fio superelástico, também com dimensão .016", como na presente pesquisa, Mohlin et al. (1991) encontraram cerca de $200 \mathrm{~g}$ com $1 \mathrm{~mm}$ de ativação. Gurgel et al. (2001b) encontraram valores, para $1 \mathrm{~mm}$ de ativação, de 930 a 1340g. Pesquisaram com condições semelhantes aos da presente pesquisa, entretanto utilizaram fios retangulares (.017" x .025"), o que explica a diferença. 
Pelas Figuras 5.1 a 5.4 observa-se uma não linearidade entre força de ativação e ativação (afastamento), tanto na ativação como na desativação, o que é característica dos fios de níquel-titânio com superelasticidade e está de acordo com os resultados de vários autores que pesquisaram sobre o assunto (MIURA et al., 1986; MIURA; MOGl; OKAMOTO, 1990, MOHLIN et al., 1991; GURGEL et al., 2001b).

As 3 marcas de fios conduziram em média, geralmente a valores diferentes entre si significativamente. O maior valor pertence à marca GAC e o menor à Morelli. Isto deve ter ocorrido devido a composições diferentes, já que as dimensões foram as mesmas. As diferenças também podem ser atribuídas a tratamentos térmicos realizados pelos fabricantes (MIURA et al., 1986). Mas as diferenças não ocorrem em todas as temperaturas de ensaio. No ensaio a $32^{\circ} \mathrm{C}$, as médias entre as três ligas, para ativações semelhantes, não apresentaram diferenças significantes entre si, o que não ocorreu nas demais temperaturas de ensaio.

O aumento das temperaturas apresentou progressivamente aumento de ativação, que está de acordo com resultados de outros autores (WATERS, 1992; IIJIMA, et al., 2002b; YANURU et al., 2003). Isto ocorre, provavelmente, devido a uma maior ativação térmica dos átomos, que por sua vez pode ativar a mudança das fases austenita e martensita (IIJIMA et al., 2002b).

\subsection{Diminuição da força com desativação de $0,20 \mathrm{~mm}$, a partir da ativação máxima}


Os resultados podem ser observados nas Tabelas 5.4 a 5.6. As Figuras 5.1 a 5.4 fornecem uma visão do fenômeno. As ativações até 1 e $2 \mathrm{~mm}$ não apresentaram quedas muito acentuadas de força, com a desativação de $0,20 \mathrm{~mm}$. Entretanto, elas foram bastante acentuadas nos casos da ativação até 3 e 4mm, principalmente nesta última. O gradiente de diminuição de força, considerando a unidade $1 \mathrm{~mm}$, seria $740 \mathrm{~g} / \mathrm{mm}$ para a ativação de $3 \mathrm{~mm}$ e $1320 \mathrm{~g} / \mathrm{mm}$ no caso da ativação de $4 \mathrm{~mm}$. Isto significa uma rigidez até maior do que aquela de fios de aço inoxidável ou similares (Lino (1970) - cerca de $600 \mathrm{~g} / \mathrm{mm}$, com fio de dimensões maiores). Assim, um dente fora do alinhamento de $4 \mathrm{~mm}$, no início ficaria sob uma força de cerca de $500 \mathrm{~g}$, mas que diminuiria, após movimentação de $0,20 \mathrm{~mm}$, para cerca da metade dessa carga. É provável que clinicamente isto até seria benéfico, segundo consenso, que sugere que forças menores aplicadas aos dentes são mais favoráveis (GURGEL et al., 2001b). Observando os resultados numéricos em geral e os gráficos, verifica-se que, quando com ativações que cegam a manifestar superelasticidade (ativações de 3 e $4 \mathrm{~mm}$ ), a queda inicial é mais acentuada, e tanto maior, quanto maior a ativação feita. As ativações de 1 e $2 \mathrm{~mm}$ apresentaram ua queda pequena, nos primeiros $0,20 \mathrm{~mm}$ de desativação (gradiente de $260 \mathrm{~g} / \mathrm{mm}$ com $1 \mathrm{~mm}$ de ativação ; $330 \mathrm{~g} / \mathrm{mm}$ com $2 \mathrm{~mm}$ de ativação). Foram justamente estas duas ativações que não apresentaram os platôs de superelasticidade.

Em média a marca GAC apresentou uma queda significantemente maior, mas que depende, também, de variáveis como o grau de ativação e da temperatura dos ensaios.

A diminuição acentuada da força, após ativação máxima, parece ser uma característica dos fios com superelasticidade, pois vários dos autores que apresentam gráficos com essas ligas, mostram esse comportamento (MIURA et al., 
1986; MIURA; MOGI; OKAMOTO, 1990; MOHLIN et al., 1991; WATERS, 1992; HEMINGWAY et al., 2001; GURGEL et al., 2001b; IIJIMA et al., 2002b; YANARU et al., 2003).

\subsection{Diminuição da força para desativação de $0,70 \mathrm{~mm}$, a partir da ativação máxima (3 e 4mm)}

O valor de $0,70 \mathrm{~mm}$ bi escolhido por corresponder, aproximadamente ao início dos platôs de superelasticidade. Foram tomadas as ativações de 3 e $4 \mathrm{~mm}$, pois apenas estas mostraram platôs (Tabelas 5.7 a 5.9 e Figuras 5.1 a 5.4).

A análise das Figuras 5.3 e 5.4 mostra que a diminuição das forças na desativação entre $0,20 \mathrm{~mm}$ e $0,70 \mathrm{~mm}$ é bem menor do que na desativação apenas até $0,20 \mathrm{~mm}$. Considerando-se gradientes médios (da ativação máxima até a desativação de $0,70 \mathrm{~mm}$ ) seria da ordem de $379 \mathrm{~g} / \mathrm{mm}$ ( $3 \mathrm{~mm}$ de ativação) e $623 \mathrm{~g} / \mathrm{mm}$ (4mm de ativação). São valores médios já bem menores do que no caso da desativação de $0,20 \mathrm{~mm}$.

Comparando a diminuição da força com $0,70 \mathrm{~mm}$ de desativação, verifica-se que esses valores tendem a se aproximar das forças de ativação máxima, com cerca de $100 \mathrm{~g}$ a menos. Para a ativação de $3 \mathrm{~mm}$, a força média foi de $422 \mathrm{~g}$ e a diminuição de $265 \mathrm{~g}$, diferença de $157 \mathrm{~g}$, valor já próximo da força no platô. A ativação de $4 \mathrm{~mm}$ necessitou uma força média de $537 \mathrm{~g}$ e a diminuição de $0,70 \mathrm{~mm}$ implicou numa diminuição de $436 \mathrm{~g}$, apresentando uma força de $101 \mathrm{~g}$, praticamente ao valor médio do platô (103g). Verificou-se, assim (Figuras 5.3 e 5.4), que com 
0,70mm de desativação já se aproximava o platô, principalmente na ativação de $4 \mathrm{~mm}$.

Entre marcas foram encontradas diferenças significantes, cabendo o maior valor ao material GAC e o menor ao Morelli.

A temperatura de ensaio influenciou, mas parece que não muito acentuadamente. $\mathrm{O}$ valor aumenta com o aumento da temperatura, porém foi detectada diferença significante apenas com os valores correspondentes às temperaturas de $32^{\circ} \mathrm{C}(338 \mathrm{~g})$ e $42^{\circ} \mathrm{C}(361 \mathrm{~g})$. Isto ocorreu essencialmente com a marca GAC e 4mm de ativação máxima.

Conforme já lembrado, é difícil encontrar na literatura ativações maiores como realizado nesta investigação. No entanto, lijima et al. (2002b) com 3mm de ativação apresentaram resultados com que os da presente pesquisa concordam. Com 4mm de ativação, Mohlin et al. (1991) também apresentaram características semelhantes na curva de desativação.

\subsection{Extensão máxima dos platôs (ativação máxima de 3 e $4 \mathrm{~mm}$ )}

Esta grandeza, juntamente com a força ao longo dos platôs são as mais importantes, do ponto de vista clínico, quando do emprego de fios com superelasticidade (Tabelas 5.10 a 5.12 ).

Assim existe grande interesse em conhecer-se a extensão durante a qual se manifesta força constante. Ainda é importante conhecer-se em que valores quanto ao afastamento existem os platôs. Assim, na ativação de $3 \mathrm{~mm}$ interessa saber se o platô começa no afastamento de 2,5 ou 2,0mm e termina em 1,5 ou 1,0mm. Ou o de 
ativação de $4 \mathrm{~mm}$ começa no afastamento de 3,5 ou $2,5 \mathrm{~mm}$ e termina em 1,5 ou 0,5mm. Estes conhecimentos por parte do ortodontista podem auxiliar em muito a escolha do tipo, dimensão e geometria do fio, em cada fase do tratamento.

A ativação máxima até $4 \mathrm{~mm}$ conduziu a uma extensão média do platô, de força constante de $2,2 \mathrm{~mm}$. Se inicia em torno do afastamento de $3,3 \mathrm{~mm}$ e termina em torno de $0,9 \mathrm{~mm}$ ou menos. Por sua vez, a ativação de $3 \mathrm{~mm}$ apresenta uma extensão de cerca de apenas $1,0 \mathrm{~mm}$ e se inicia em torno do afastamento de $2,2 \mathrm{~mm}$ e termina em torno de $1,1 \mathrm{~mm}$. As médias de extensão foram influenciadas pela marca Morelli, que apresentaram valores muito baixos na extensão (dentro do critério fixado, conforme visto em Materiais e Métodos). Isto ocorreu principalmente na temperatura de ensaio de $32^{\circ} \mathrm{C}$. Contanto que a média geral da marca Morelli foi a menor das três ensaiadas.

A temperatura de $32^{\circ} \mathrm{C}$ conduziu à menor média significativamente, não tendo sido encontrada diferença entre as temperaturas de 37 e $42^{\circ} \mathrm{C}$. A marca Morelli apresentou, na temperatura de ensaio de $32^{\circ} \mathrm{C}$, um final de platô com afastamento ainda muito grande, o que fez com que as extensões se tornassem relativamente pequenas. A Figura 5.3 ilustra bem esse comportamento. Assim as marcas Forestadent e GAC apresentaram em todas as temperaturas razoável paralelismo dos platôs nas três temperaturas de ensaio na ativação máxima de $3 \mathrm{~mm}$. Já com a marca Morelli fica bem mais difícil caracterizar um platô com paralelismo ao eixo das ativações.

Com a ativação máxima de 4mm (Figura 5.4) podem ser feitas observações interessantes. A marca Forestadent, nas três temperaturas de ensaio, apresentou platôs bem característicos. Na marca GAC na temperatura de ensaio de $32^{\circ} \mathrm{C}, \mathrm{o}$ platô ficou bem nítido. Mas nas temperaturas de 37 e $42^{\circ} \mathrm{C}$, no início dos platôs (na 
desativação), a força é menor, aumentando à medida que o afastamento se torna menor, para em seguida diminuir, nas proximidades da origem. A extensão nos casos é relativamente grande, pois foi considerado o início com duas leituras de força em seqüência iguais e $\pm 20 \mathrm{~g}$, em relação a esta, o que aumentou a extensão. A marca Morelli conduziu a resultados bem diversos. Na temperatura de $32^{\circ} \mathrm{C}$ houve praticamente queda contínua de força, pouco se caracterizando a extensão do platô. A 37 e $42^{\circ} \mathrm{C}$ para essa marca, os platôs se caracterizaram bem mais nitidamente, daí os seus valores numéricos não se afastarem tanto daqueles das outras marcas.

Torna-se difícil de comparar a extensão dos platôs da presente pesquisa, com resultados da literatura, já que quase todos os trabalhos apresentam ativações máximas de até $2 \mathrm{~mm}$. Mas, conforme pode ser observado nas Figuras 5.1 e 5.2, até $2 \mathrm{~mm}$ de ativação não se caracterizaram os platôs na desativação. lijima et al. (2002b), com 3mm de ativação, dependendo da liga, encontraram aspectos com que os da presente pesquisa podem ser assemelhados. Por outro lado, com $4 \mathrm{~mm}$ de ativação, não se nota um platô característico, com paralelismo, conforme pesquisa de Mohlin et al. (1991).

\subsection{Forças nos platôs ( 3 e 4 mm de ativação)}

É de grande importância esta grandeza (Tabelas 5.13 a 5.15), quando o intuito for de realizar a movimentação dental sob força constante e leve. De acordo com Proffit (2002) as forças ótimas para a movimentação dentária varia de 10 a $120 \mathrm{~g}$, mas que depende da natureza do movimento e do dente. Para o movimento 
de translação sugeriu um valore de 70 a $120 \mathrm{~g}$. Os valores médios encontrados na presente pesquisa se enquadram bastante nesse intervalo, bem como o tipo de ensaio simula mais um movimento de translação. A ativação até $3 \mathrm{~mm}$ ultrapassa o valor máximo e aquela até $4 \mathrm{~mm}$, se enquadra no intervalo. Só que isto depende, também, de outras condições, como liga e temperatura de ativação. Freqüentemente os valores encontrados ultrapassaram os limites do intervalo sugerido. Foram encontrados valores desde $43 \mathrm{~g}$ até $180 \mathrm{~g}$ nos platôs, dependendo das condições.

Em geral a ativação maior apresenta no platô força menor. Mas a magnitude da ativação depende, clinicamente, do desnivelamento do dente.

Maior temperatura conduziu a maiores forças, mas a mais duradoura, no meio bucal, é próxima de $37^{\circ} \mathrm{C}$, que é praticamente a do corpo humano. Para $3 \mathrm{~mm}$ de ativação, e a $37^{\circ} \mathrm{C}$, o fio Morelli apresentou valor dentro do intervalo (PROFFIT, 2002), com $93 \mathrm{~g}$ e as outras marcas, nestas condições apresentaram valores maiores. Nas demais condições semelhantes, a ativação até $4 \mathrm{~mm}$ apresenta valores menores. Mas como já foi lembrado, quem determina o valore da deflexão para a ativação é a posição do dente. A menor força encontrada no platô, como na desativação com a ativação máxima está de acordo com os resultados de Meling e Odegaard (2001).

Temperaturas de ensaio maiores conduziram a forças maiores, o que está de acordo com os resultados de vários autores (WATERS, 1992; IIJIMA et al., 2002b; YANURU et al., 2003).

Valores de forças diferentes encontrados não estão de acordo com alguns outros autores (MIURA; MOGI; OKAMOTO, 1990; GURGEL et al., 2001b). 


\subsection{Desativação até registrar a força de $50 \mathrm{~g}$, a partir de 0,80 e $1,80 \mathrm{~mm}$ (respectivamente 1 e $2 \mathrm{~mm}$ de ativação) e a partir do final do platô (com 3 e $4 \mathrm{~mm}$ de ativação)}

O interesse desta grandeza é verificar quanto de deslocamento ainda é disponível antes da força diminuir para $50 \mathrm{~g}$ nas ativações de 1 e $2 \mathrm{~mm}$ e no final do platô, nas ativações de 3 e 4 mm (Tabelas 5.16 a 5.18).

A ativação de $1 \mathrm{~mm}$ em média só dispunha uma extensão de $0,40 \mathrm{~mm}$, que parece ser pouco, do ponto de vista clínico. A ativação de $2 \mathrm{~mm}$, dispõe de $1,27 \mathrm{~mm}$, o que parece ser razoável, propiciando uma movimentação dentária considerável. Após o término dos platôs, as extensões são, também, muito pequenas e maior para $3 \mathrm{~mm}$ de ativação $(0,50 \mathrm{~mm})$ do que para $4 \mathrm{~mm}(0,15 \mathrm{~mm})$. O menor valor para $4 \mathrm{~mm}$ de ativação encontra explicação no fato do platô correspondente ser provido de menor força, e o final do platô estar um pouco mais próximo da origem.

As marcas não apresentaram valores muito diferentes, embora maior para a Forestadent.

A temperatura conduziu a valor médio significantemente menor apenas para a de $32^{\circ} \mathrm{C}$. O fio Morelli, com $4 \mathrm{~mm}$ de ativação apresentou um valor negativo de $0,48 \mathrm{~mm}$. Isto significa que a força no platô foi menor do que $50 \mathrm{~g}$, atnes de chegar ao seu final. De fato, a força média no platô correspondente a estas condições foi de $43 \mathrm{~g}$ apenas (Tabela 5.15).

Nesta grandeza, como na maioria das seguintes, não se encontram resultados detalhados na literatura, para fins de comparação. 


\subsection{Força ao iniciar a desativação até $50 \mathrm{~g}$, em 0,80 e 1,80mm (respectivamente} 1 e $2 \mathrm{~mm}$ de ativação) e a partir do final do platô (3 e $4 \mathrm{~mm}$ de ativação)

O interesse dessa grandeza (Tabelas 5.19 a 5.21) é verificar a disponibilidade de força nas situações respectivas, até atingir $50 \mathrm{~g}$ na desativação.

O maior valor corresponde à ativação máxima de $2 \mathrm{~mm}$, o que é compreensível, já que a força de ativação de $2 \mathrm{~mm}$ foi maior do que $1 \mathrm{~mm}$ e nenhuma das duas apresentou platô de superelasticidade. A ativação de $3 \mathrm{~mm}$ apresentou um valor maior que a de $4 \mathrm{~mm}$, o que está coerente, uma vez que a força no platô de $4 \mathrm{~mm}$ foi menor do que no de $3 \mathrm{~mm}$.

As marcas também apresentaram diferenças significantes, mas que numericamente não são exageradamente altas.

A temperatura conduziu a diferenças significantes e os seus valores aumentaram com o aumento da mesma.

\subsection{Afastamento da origem ao registrar $50 \mathrm{~g}$ de força na desativação}

Esta grandeza (Tabelas 5.22 a 5.24) tem o interesse de informar ao ortodontista a que distância, ou afastamento, está a posição a ser alcançada, quando a força máxima seria apenas de $50 \mathrm{~g}$, que estaria aquém do valor mínimo desejável para a translação de um dente (PROFFIT, 2002). 
Quanto maior foi a ativação, maior é o afastamento, variou de $0,40 \mathrm{~mm}$ ( $1 \mathrm{~mm}$ de ativação) até $0,94 \mathrm{~mm}$ ( $4 \mathrm{~mm}$ de ativação), sendo os 4 valores para as 4 ativações significantemente diferentes entre si.

Das três marcas, a Morelli ficou a mais distante da origem $(0,84 \mathrm{~mm})$. Isto se deve, essencialmente, à condição de $32^{\circ} \mathrm{C}$ com ativação de $4 \mathrm{~mm}$, que apresentou, nesta condição um valor de 2,72mm (Tabela 5.24). Clinicamente, isto provavelmente não se manifesta tão acentuadamente, devido à temperatura de permanência do arco de fio ficar mais próximo de $37^{\circ} \mathrm{C}$.

A temperatura de $32^{\circ} \mathrm{C}$ conduziu ao maior valor significantemente, em relação às de 37 e $42^{\circ} \mathrm{C}$. Novamente isto pode ser atribuído, principalmente à condição de $4 \mathrm{~mm}$ de ativação na marca Morelli.

Os gráficos dos trabalhos de Miura, Mogi e Ohura (1988) e de Mohlin et al. (1991) mostram resultados com que os da presente pesquisa se podem assemelhar. Por outro lado, o comportamento no caso é bem diferente do que quando se trata de alças de retração, conforme pode ser observado no trabalho de Lino (1970). Esse autor, embora empregando liga com módulo de elasticidade bem maior e dimensões diferentes, com alças tipo clínicas, fechadas sob tensão no momento da conformação, e submetidos a tratamento térmico de recuperação, verificou que elas voltavam à origem (afastamento zero), ainda mantendo uma força de $50 \mathrm{~g}$. Isto é, para ativar, abrir a alça, teria que ser aplicada uma força acima de $50 \mathrm{~g}$. Já no caso da presente pesquisa, ao ser atingida a força de $50 \mathrm{~g}$ na desativação, o afastamento variou em torno de 0,40 a $0,94 \mathrm{~mm}$, conforme o grau de ativação.

\subsection{Deformação permanente ao alcançar força zero na desativação}


Esta grandeza (Tabelas 5.25 a 5.27) mostra a que distância o dente ainda se encontra da posição de nivelamento, quando a força de movimentação ficou reduzida a zero.

A deformação permanente média variou de $0,20 \mathrm{~mm}$ (ativação $1 \mathrm{~mm}$ ) a 0,84mm (ativação $4 \mathrm{~mm}$ ), isto é, quanto maior a ativação, maior foi a deformação permanente ou residual.

A marca Forestadent apresentou um valor significantemente menor que as duas outras marcas.

As temperaturas conduziram a valores significantemente diferentes entre si, entretanto o menor valor corresponde à temperatura intermediária $\left(37^{\circ} \mathrm{C}\right)$ e não às extremas $\left(32^{\circ} \mathrm{C}\right.$ e $\left.42^{\circ} \mathrm{C}\right)$.

Os resultados da presente investigação não estão de acordo com os de alguns outros autores, que praticamente encontraram força nula, com afastamento, também, quase nulo (MIURA, MOGI e OHURA (1988), em alguns casos; YANURU et al. (2003), também em alguns casos, conforme o fio). Mohlin et al. (1991), com fio NiTi Chinês encontraram valor de deformação permanente nulo. Ainda, Yanuru et al. (2003), conforme a liga do fio, utilizando arco total ligado a braquetes, encontraram deformação permanente nula, ou até $1,7 \mathrm{~mm}$, conforme o fio.

A deformação permanente observada deve ser devido à resistência de fricção, que impedia a volta total de deflexão, quando a força se tornava muito pequena na desativação. A favor desta explicação vem a observação feita, durante os ensaios, levando em consideração que os arcos eram contidos nos bráquetes. Assim, quando o arco ao término do descarregamento apresentava pequena deflexão, na região do ensaio, esta desaparecia ao liberar o arco dos bráquetes. 
A resistência do arco ao longo dos bráquetes foi bastante estudada por vários autores, o que confirma a observação feita na presente pesquisa. Kapila et al. (1990a), para fio de .016" de NiTi, encontraram uma resistência de fricção de 83g. Downing, McCabe e Gordon (1995), com fio .018" NiTi, encontraram cerca de $62 \mathrm{~g}$. Thorstenson e Kusy (2002) encontraram resistência ao deslizamento de cerca de 12 a $47 g$.

\subsection{Algumas considerações sobre as transformações de fases dos fios ortodônticos de níquel-titânio}

O comportamento diferente dos fios de níquettitânio, durante a ativação e desativação, é dependente da transformação de fases. O que por sua vez é dependente da magnitude da solicitação do material, bem como de condições complexas, como composição da liga e do tratamento térmico anterior.

Meling e Odegaard (2001) concluíram, em relação aos fios de níquel-titânio com superelasticidade: a força exercida or um fio de superelasticidade na fase de desativação é dependente do "histórico da deformação".

Miyazaki e Otsuka (1986), já apresentaram um estudo bastante profundo sobre a transformação de fases nas ligas de Ni-Ti. Uma liga, de composição em porcentagem atômica $\mathrm{Ti} 50,6 \% \mathrm{Ni}$ e submetida a 3 tratamentos térmicos, todos seguidos por resfriamento em água gelada: 1$)$ a $1273 \mathrm{~K}\left(1000^{\circ} \mathrm{C}\right)$, por uma hora; 2$)$ a $673 \mathrm{~K}\left(400^{\circ} \mathrm{C}\right)$ por uma hora, após o tratamnto $\left.(1) ; 3\right)$ a $673 \mathrm{~K}\left(400^{\circ} \mathrm{C}\right)$, por uma hora após trabalho mecânico a frio. No tratamento (1) encontraram a fase $A_{f}$ (final da fase austenítica) pelos $253 \mathrm{~K}\left(-20^{\circ} \mathrm{C}\right)$. Ao chegar à temperatura, pelos $233 \mathrm{~K}\left(-40^{\circ} \mathrm{C}\right)$ encontraram a fase $M_{5}$ (início da fase martensítica) e pelos $183 \mathrm{~K}\left(-90^{\circ} \mathrm{C}\right)$, o final 
dessa fase $\left(\mathrm{M}_{\mathrm{f}}\right)$. Nos tratamentos (2) e (3), os autores encontraram as temperaturas de transformação em valores mais altos, bem como a fase $A_{s}$ (início da fase austenítica). O interessante que nesses dois tratamentos encontraram, em temperaturas mais altas que a fase $A_{r}$ (final da fase austenítica) uma nova fase T'R (fase romboedral) em torno de $316 \mathrm{~K}\left(43^{\circ} \mathrm{C}\right)$ e que se transformava no restriamento a TR, pelos $303 \mathrm{~K}\left(30^{\circ} \mathrm{C}\right)$. As fases mencionadas foram observadas com aspectos semelhantes em trabalho posterior, apresentado por Miyazaki e Wayman (1988).

Yoneyama et al. (1993) empregaram fios de $\mathrm{Ni}-\mathrm{Ti}$ comerciais e os submeteram a tratamentos térmicos entre $673 \mathrm{~K}$ e $813 \mathrm{~K}\left(400\right.$ e $\left.450^{\circ} \mathrm{C}\right), 20$ em $20^{\circ} \mathrm{C}$, por meia hora. Esses fios em seqüência foram submetidos a ensaios de deflexão. Verifica-se, pelos gráficos do trabalho, que à medida que aumentava a temperatura o aspecto da desativação se aproximava a um platô.

A determinação das temperaturas de transformação de fases de fios ortodônticos de níquel-titânio foi abordada, também, por Bradley, Brantley e Culbertson (1996), para elucidar discrepâncias em recentes publicações da época sobre o comportamento desses novos materiais. A pesquisa foi desenvolvida na faixa de temperatura de $-170^{\circ} \mathrm{C}$ a $100^{\circ} \mathrm{C}$. Duas formas diferentes foram observadas em relação à fase intermediária $\mathrm{R}$ presente ou não na transformação da fase martensítica para a austenítica. Na transformação reversa, da fase austenítica para a martensítica, sempre aparecia a fase $R$. Os resultados indicaram que os processos de transformação são largamente similares em fios de $\mathrm{Ni}-\mathrm{Ti}$ superelásticos, de memória de forma à temperatura ambiente e não superelásticos. Diferenças em propriedades de dobramento desses fios à temperatura ambiente e a $37^{\circ} \mathrm{C}$ são devidos às proporções relativas das fases metalúrgicas na microestrutura. 
Kawashima, Ohno e Sachdeva (1999) verificaram que quanto menor a temperatura $A_{f}$, maior força fica envolvida na ativação e desativação.

Barwart, Rollinger e Burger (1999) verificaram que as temperaturas das fases $M_{f}$ e $A_{s}$ dos fios testados encontram-se abaixo da temperatura ambiente. Assim, à temperatura ambiente ou pouco abaixo, todas as molas de NiTi testadas exerciam propriedades superelásticas. Isto mostra que para tratamentos ortodônticos a manutenção da superelasticidade pode se manter durante as refeições.

lijima et al. (2002a) concluíram pelos resultados a natureza complexa do comportamento da transformação de fases nos fios de níquettitânio, que por sua vez é influenciado pelo estado de tensões, temperatura ambiente e temperatura da fase $A_{f}$ de cada produto, que por sua vez é uma função complexa da composição da liga e da história do processamento do fio.

Segundo Fischer-Brandies et al. (2003), as propriedades mecânicas dependem do estado inicial; forças moderadas no platô apenas podem ser obtidas com fios com fase martensítica. Ainda, o platô da superelasticidade é utilizado apenas parcialmente, se é que chega a isto, quando é necessário apenas um mínimo de nivelamento.

Parece que $\circ$ tipo de mensuração empregado para 0 estudo das transformações de fase também é de grande importância. Muitas das investigações foram conduzidas com a Calorimetria Diferencial de Varredura (DSC). Brantley, lijima e Grentzer (2003), empregaram o referenciado método com modulação de temperatura (TMDSC - Temperature-modulated differencial scanning calorimetry) e chegaram a uma série de conclusões interessantes. O método TMDSC mostrou que a transformação de fases em fios ortodônticos de níquel-titânio é bem mais 
complexa do que as transformações observadas apenas com o método convencional DSC. Enquanto o método convencional DSC sugeriu que ocorre uma transformação direta entre as fases martensítica e austenítica, o método TMDSC mostrou que, durante o aquecimento do fio $\mathrm{Ni}-\mathrm{Ti} \mathrm{Neo}$ Sentalloy, há uma transformação inicial da fase martensita para a $R$, seguida da tranformação da fase R para austenita. No resfriamento ocorre o inverso das duas transformações.

Verifica-se o quanto é complexa a ocorrência da superelasticidade, dependente de muitos fatores, que ainda não estão totalmente resolvidos pelos fabricantes e informações também não são transmitidas em grau suficiente aos profissionais.

\subsection{Considerações finais}

Uma apreciação geral dos resultados (Tabelas 5.1 a 5.27), correspondentes a valores específicos, e as Figuras 5.1 a 5.4, que fornecem informações visuais mais gerais, mostra a grande diferença de comportamento nas diversas condições experimentais investigadas.

Observando as Figuras 5.1 a 5.4, verifica-se que rigorosamente não se encontram diferenças muito acentuadas entre as marcas de fios e temperaturas de ensaio, embora a marca Morelli, no ensaio a $32^{\circ} \mathrm{C}$, apresente certos valores no platô de superelasticidade mais deficientes. Por outro lado, chama a atenção os diferentes aspectos das curvas em decorrência das diversas ativações máximas (1, 2, 3 e $4 \mathrm{~mm})$, comparando uma figura com a outra. 
As ativações 1 e 2 são semelhantes no aspecto geral, apenas a de $2 \mathrm{~mm}$ requer mais força. A queda de força para a desativação de $0,2 \mathrm{~mm}$ não é muito acentuada. Em todos os casos, nota-se uma pequena deformação permanente (com força na desativação nula), mas que é devido à força de fricção dos arcos nos bráquetes. O que chama atenção nessas ativações é a ausência dos platôs de superelasticidade. Desta forma se o desnivelamento dos dentes não ultrapassar $2 \mathrm{~mm}$, com a ausência do platô, não haverá movimentação dentária com força constante. Seria semelhante aos casos de fios de aço inoxidável ou semelhantes, embora a rigidez seja menor com dimensões de fio iguais, já que o módulo de elasticidade do fio de níquel-titânio é bem menor que do aço. Uma rigidez semelhante poderia ser conseguida com fio de aço inoxidável de dimensões menores. Como as forças se tornam nulas nas proximidades da origem, outros procedimentos precisam ser tomadas pelo profissional para levar o dente à posição correta de nivelamento.

Em relação às ativações de 1 e $2 \mathrm{~mm}$, aspectos bem diferentes, das curvas de ativação e principalmente desativação, são notados com as correspondentes de 3 e $4 \mathrm{~mm}$. Nestes casos as forças de ativação máxima já são bem maiores. A diminuição das forças com desativação de $0,20 \mathrm{~mm}$ também, foi bastante acentuada. Foi maior ainda, com desativação de $0,70 \mathrm{~mm}$, principalmente na ativação máxima de $4 \mathrm{~mm}$. O que chama atenção no caso é a existência dos platôs na desativação, com praticamente força constante durante uma certa extensão. Na ativação de $3 \mathrm{~mm}$, o platô começou em cerca de 2,2mm de afastamento e terminou em cerca de 1,0mm. Na ativação de $4 \mathrm{~mm}$, o platô existe entre os afastamentos de cerca de 3,3 e $0,9 \mathrm{~mm}$. A força média ao longo do platô da ativação de $3 \mathrm{~mm}$ foi de $132 \mathrm{~g}$ e a da 
ativação de $4 \mathrm{~mm}$, foi de $103 \mathrm{~g}$. Seriam forças relativamente baixas e fisiologicamente favoráveis à movimentação dentária.

Uma preocupação a respeito dos resultados em relação aos platôs seria a limitação imposta para a sua utilização, quanto à posição do afastamento. Assim, nas ativações de 1 e $2 \mathrm{~mm}$ não seria possível utiliza-lo, pela sua ausência. $\mathrm{Na}$ ativação de $3 \mathrm{~mm}$ a força constante atuaria entre cerca de 2,2 a $1 \mathrm{~mm}$ de afastamento. Na ativação de $4 \mathrm{~mm}$ a ação no platô estaria entre os afastamentos de 3,3 e 0,9mm, assim, a utilização de força constante se limitaria a essa faixa.

Talvez no futuro os fabricantes consigam introduzir nos fios propriedades tais que a superelasticidade possa ser utilizada em intervalos de afastamentos bem mais amplos, o que tornaria a utilização bem mais favorável. 


\section{CONCLUSÕES}

Tendo em vista os resultados obtidos e discutidos, parece lícito concluir que:

\subsection{Forças máximas na ativação}

7.1.1 Quanto maior a ativação, maior é a força necessária para se alcançada.

7.1.2 A marca Morelli apresentou o menor valor médio, e a GAC o maior, mas isto depende das temperaturas e grau de ativação.

7.1.3 Quanto maior a temperatura na ativação, maior a força, mas que depende da ativação e da marca.

7.2 Diminuição da força com desativação de $0,20 \mathrm{~mm}$

7.2.1 Em média, quanto maior a ativação, maior a diminuição da força, mas que depende, também do material e temperatura.

\subsection{Diminuição da força com desativação de $0,70 \mathrm{~mm}$ (ativações de 3 e $4 \mathrm{~mm}$ )}

7.3.1 Na desativação de $4 \mathrm{~mm}$ de ativação, a diminuição foi maior que em todas as demais condições.

\subsection{Extensão dos platôs ( 3 e 4 mm de ativação)}


7.4.1 A extensão do platô fio bem maior na ativação de $4 \mathrm{~mm}$ do que na de $3 \mathrm{~mm}$, o que só não ocorreu com o fio da marca Morelli, na temperatura de 32oC.

7.4.2 Em média, o fio Morelli apresentou a menor extensão e o GAC a maior, o que ocorreu principalmente na temperatura de $320 \mathrm{C}$.

7.4.3 A extensão do platô no geral depende pouco da temperatura, excluindo o fio Morelli, na de $320 \mathrm{C}$.

7.4.4 O início dos platôs é influenciado pelo grau de ativação. Inicia-se aproximadamente após $0,7 \mathrm{~mm}$ de desativação. $O$ término ocorre proximamente de $1 \mathrm{~mm}$ de afastamento.

\subsection{Força nos platôs ( 3 e $4 \mathrm{~mm}$ de ativação)}

7.5.1 A força no platô de $3 \mathrm{~mm}$ de ativação foi maior do que na de $4 \mathrm{~mm}$.

7.5.2 O fio Morelli em média apresentou a menor força e o Forestadent a maior.

7.5.3 Quanto maior foi a temperatura de ensaio, maior era a força no platô, principalmente nas marcas Forestadent e GAC.

7.6 Desativação até $50 \mathrm{~g}$, a partir de 0,80 e 1,80mm (respectivamente ativações de 1 e $2 \mathrm{~mm}$ ) e a partir do final do platô (3 e $4 \mathrm{~mm}$ de ativação)

7.6.1 A ativação até $2 \mathrm{~mm}$ forneceu a maior extensão na desativação e o de $4 \mathrm{~mm}$ a menor.

7.6.2 As marcas GAC e Morelli não apresentaram diferenças entre si e seus valores foram significantemente menores que o da Forestadent.

7.6.3 A temperatura de $320 \mathrm{C}$ conduziu a menor valor médio significantemente. 
7.6.4 O fio Morelli, com ativação de $4 \mathrm{~mm}$ a $320 \mathrm{C}$ apresentou um valor negativo, porque a força antes do final do platô já era menor que $50 \mathrm{~g}$.

7.7 Forças ao iniciar-se a desativação até $50 \mathrm{~g}$, em 0,80 e $1,80 \mathrm{~mm}$ (respectivamente 1 e $2 \mathrm{~mm}$ de ativação) e no final do platô (3 e $4 \mathrm{~mm}$ de ativação)

7.7.1 A ativação de $2 \mathrm{~mm}$ continha a maior força e a de $4 \mathrm{~mm}$ a menor. De marcas em ordem decrescente foi Forestadent, GAC e Morelli. Quanto maior a temperatura na ativação, maior a força disponível.

\subsection{Afastamento da origem ao registrar $50 \mathrm{~g}$ de força}

7.8.1 Quanto maior a ativação, maior o afastamento da origem. O maior valor corresponde à marca Morelli, que foi, principalmente na ativação de $4 \mathrm{~mm}$ e temperatura de $320 \mathrm{C}$. A temperatura não teve influência acentuada, embora o maior valor corresponda a $320 \mathrm{C}$.

\subsection{Deformação permanente}

7.9.1 Quanto maior a ativação, maior é a deformação permanente. Das marcas a menor pertence a Forestadent, não tendo sido significantemente diferentes entre si as outras duas. A temperatura de $320 \mathrm{C}$ conduziu à maior deformação permanente. 


\section{REFERÊNCIAS ${ }^{1}$}

Ackerman JL, Chanda LH, Creekmore TD, Meyer M, Neson, GD. Round table Nitinol wire. J Clin Orthod 1978;12(7):479-85.

Airoldi G, Riva G, Vanelli M, Filippi V, Garattini G. Oral environment temperature changes induced by cold/hot liquid intake. Am J Orthod Dentofacial Orthop 1997;112(1):58-63.

Andreasen GF. Variable continuous forces. Aust Dent J 1970;15(1):10-5.

Andreasen GF, Brady PR. A use hypothesis for 55 Nitinol wire for orthodontics. Angle Orthod 1972;42(2):172-7.

Andreasen GF, Hilleman TB. An evaluation of 55 cobalt substituted Nitinol wire for use in orthodontics. J Am Dent Assoc 1971;82(6):1373-5.

Andreasen GF, Morrow RE. Laboratory and clinical analyses of nitinol wire. Am J Orthod 1978;73(2):142-51.

Andreasen GF, Bigelow H, Andrews JG. 55 Nitinol wire: force developed as a function of "elastic memory". Aust Dent J 1979;24(3):146-9.

Andreasen G, Wass K, Chan KC. A review of superelastic and thermodynamic nitinol wire. Quintessense Int 1985;16(9):623-6.

Angolkar PV, Arnold JV, Nanda RS, Duncanson MG. Force degradation of closed coil springs: an in vitro evaluation. Am J Orthod Dentofacial Orthop 1992;102(2):12733.

Baldwin PD, Pender N, Last KS. Effects on tooth movement of force delivery from nickel-titanium archwires. Eur J Orthod 1999;21(5):481-9.

\footnotetext{
${ }^{1}$ De acordo com Estilo Vancouver. Abreviatura de periódicos segundo base de dados MEDLINE.
} 
Barwart $\mathrm{O}$. The effect of temperature change on the load value of Japanese NiTi coil springs in the superelastic range. Am J Orthod Dentofacial Orthop 1996;110(5):5538.

Barwart O, Rollinger JM, Burger A. An evaluation of the transition temperature range of super-elastic orthodontic NiTi springs using differential scanning calorimetry. Eur $\mathrm{J}$ Orthod 1999;21(5):497-502.

Bishara SE, Winterbottom JM, Sulieman AA, Rim K, Jakobsen JR. Comparisons of the thermodynamic properties of three nickel-titanium orthodontic archwires. Angle Orthod 1995;65(2):117-22.

Bradley TG, Brantley WA, Culbertson BM. Differential scanning calorimetry (DSC) analyses of superelastic and nonsuperelastic nickel-titanium orthodontic wires. Am J Orthod Dentofacial Orthop 1996;109(6):589-97.

Brantley WA, lijima M, Grentzer TH. Temperature-modulated DSC provides new insight about nickel-titanium wire transformations. Am J Orthod Dentofacial Orthop 2003;124(4):387-94.

Burstone CJ, Baldwin JJ, Lawless DT. The application of continuous forces to orthodontics. Angle Orthod 1961;31(1):1-14.

Burstone CJ, Qin B, Morton JY. Chinese NiTi wire - a new orthodontic alloy. Am J Orthod 1985;87(6):445-52.

Chen R, Zhi YF, Arvystas MG. Advanced Chinese NiTi alloy wire and clinical observations. Angle Orthod 1992;62(1):59-66.

Civjan S, Huget EF, DeSimon LB. Potential applications of certain nickel-titanium (Nitinol) alloys. J Dent Res 1975;54(1):89-96.

Clocheret K, Willems G, Carels C, Celis JP. Dynamic frictional behaviour of orthodontic archwires and brackets. Eur J Orthod 2004;26(2):163-70.

Conley HW, Woods RW, Anholm JM, Zwemer TJ. A slide rule for archwire selection. Angle Orthod 1971(2);41:153-6. 
Dalstra M, Melsen B. Does the transition temperature of $\mathrm{Cu}-\mathrm{NiTi}$ archwires affect the amount of tooth movement during alignment? Orthod Craniofac Res 2004;7(1):21-5.

Downing A, McCabe JF, Gordon PH. The effect of artificial saliva on the frictional forces between orthodontic brackets and archwires. Br J Orthod 1995;22(1):41-6.

Evans TJW, Durning P. Aligning archwires, the shape of things to come? - A fo urth and fifth phase of force delivery. Br J Orthod 1996;23(3):269-75.

Ferreira ES, Mundstock CA, Müller CM. A utilização de fios metálicos em ortodontia. Rev Fac Odontol Porto Alegre 1998;39(1):23-30.

Fischer-Brandies H, Es-Souni M, Kock N, Raetzke K, Bock O. Transformation behavior, chemical composition, surface topography and bending properties of five selected 0.016" x 0.022" NiTi archwires. J Orofac Orthop 2003;64(2):88-99.

Fukuizumi M, Kakigawa $\mathrm{H}$, Kozono Y. Utility of $\mathrm{Ni}$-Ti shape memory orthodontic wire. Dent Mater J 1999;18(4):413-24.

Garrec $\mathrm{P}$, Jordan L. Stiffness in bending of a superelastic Ni-Ti orthodontic wire as a function of cross-sectional dimension. Angle Orthod 2004;74(5):691-6.

Gurgel JA, Ramos AL, Kerr SD. Fios ortodônticos. Rev Dental Press Ortod Ortop Fac 2001a;6(4):103-14.

Gurgel JA, Kerr S, Powers JM, Lecrone V. Force-deflection porperties of superelastic nickel-titanium archwires. Am J Orthod Dentofacial Orthop 2001b;120(4):378-82.

Gurgel JA, Kerr S, Powers JM, Pinzan A. Torsional properties of commercial nickeltitanium wires during activation and deactivation. Am J Orthod Dentofacial Orthop 2001c;120(1):76-9.

Hain M, Dhopatkar A, Rock P. The effect of ligation method on friction in sliding mechanics. Am J Orthod Dentofacial Orthop 2003;123(4):416-22.

Han S, Quick DC. Nickel-titanium spring properties in a simulated oral evironment. Angle Orthod 1993;63(1):67-72. 
Harris EF, Newman SM, Nicholson JA. Nitinol arch wire in a simulated oral environment: changes in mechanical properties. Am J Orthod Dentofacial Orthop 1988;93(6):508-13.

Hazel RJ, Rohan GJ, West VC. Force relaxation in orthodontic arch wires. Am J Orthod 1984;86(5):396-402.

Hemingway R, Williams RL, Hunt JA, Rudge SJ. The influence of bracket type on the force delivery of Ni-Ti archwires. Eur J Orthod 2001;23(3):233-41.

Ho KS, West VC. Friction resistance between edgewise brackets and archwires. Aust Orthod J 1991;12(2):95-9.

Hurst CL, Duncanson MG, Nanda RS, Angolkar PV. An evaluation of the shapememory phenomenon of nickel-titanium orthodontic wires. Am J Orthod Dentofacial Orthop 1990;98(1):72-6.

lijima M, Ohno H, Kawashima I, Endo K, Mizoguchi I. Mechanical behavior at different temperatures and stresses for superelastic nickel-titanium orthodontic wires having different transformation temperatures. Dent Mater 2002a;18(1):88-93.

lijima M, Ohno H, Kawashima I, Endo K, Brantley WA, Mizoguchi I. Micro X-ray diffraction study of superelastic nickel-titanium orthodontic wires at different temperatures and stresses. Biomaterials 2002b;23(8):1769-74.

Ingram SB, Gipe DP, Smith RJ. Comparative range of orthodontic wires. Am J Orthod Dentofacial Orthop 1986;90(4):296-307.

Iwasaki LR, Beatty MW, Randall CJ, Nickel JC. Clinical ligation forces and intraoral friction during sliding on a stainless steel archwire. Am J Orthod Dentofacial Orthop 2003;123(4):408-15.

Kapila S, Sachdeva R. Mechanical properties and clinical applications of orthodontic archwires. Am J Orthod Dentofacial Orthop 1989;96(2):100-9.

Kapila S, Angolkar PV, Duncanson MG, Nanda RS. Evaluation of friction between edgewise stainless steel brackets and orthodontic wires of four alloys. Am J Orthod Dentofacial Orthop 1990a;98(2):117-26. 
Kapila S, Sakima T, Miyazaki S, Sachdeva R. Ligas ortodônticas correntemente em uso. Revisão (Parte I). Rev Odontol Univ São Paulo 1990b;4(4):334-42.

Kapur R, Sinha PK, Nanda RS. Frictional resistance in orthodontic brackets with repeated use. Am J Orthod Dentofacial Orthop 1999;116(4):400-4.

Kawashima I, Ohno H, Sachdeva R. Relationship between Af temperature and load changes in $\mathrm{Ni}$-Ti orthodontic wire under differente thermomechanical conditions. Dent Mater J 1999;18(4):403-12.

Klump JP, Duncanson MG Jr, Nanda RS, Currier GF. Elastic energy/stiffness ratios for selected orthodontic wires. Am J Orthod Dentofacial Orthop 1994;106(6):588-96.

Kusy RP. Influence of force systems on archwire-bracket combinations.

Am J Orthod Dentofacial Orthop 2005;127(3):333-42.

Kusy RP. A review of contemporary archwires: Their properties and characteristics. Angle Orthod 1997;67(3):197-207.

Kusy RP, Greenberg AR. Comparison of the elastic properties of nickel-titanium and beta titanium arch wires. Am J Orthod 1982;82(3):199-205.

Kusy RP, Stevens LE. Triple-stranded stainless steel wires - Evaluation of mechanical properties and comparison with titanium alloy alternatives. Angle Orthod 1987;57(1):18-32.

Kusy RP, Wilson TW. Dynamic mechanical properties of straight titanium alloy wires. Dent Mater 1990;6(4):228-36.

Lee JH, Park JB, Andreasen GF, Lakes RS. Thermomechanical study of $\mathrm{Ni}$-Ti alloys. J Biomed Mater Res 1988;22(6):573-88.

Lino AP. Avaliação de propriedades mecânicas de algumas formas de alças de retração ortodôntica, em função do tratamento térmico [Tese Doutorado]. São Paulo: Faculdade de Odontologia da Universidade de São Paulo;1970.

Lipshatz J, Brockhurst PJ, West VC,. Clinical note no 11 - Mechanical properties in bending of shape-memory wires. Aust Dent J 1992;37(4):315-6. 
Loftus BP, Årtun J, Nicholls JI, Alonzo TA, Stoner JA. Evaluation of friction during sliding tooth movement in various bracket-arch wire combinations. Am J Orthod Dentofacial Orthop 1999;116(3):336-45.

Lopez I, Goldberg J, Burstone CJ. Bending characteristics of nitinol wire. Am J Orthod 1979;75(5):569-75.

Manhartsberger $\mathrm{C}$, Seidenbusch $\mathrm{W}$. Force delivery of $\mathrm{Ni}$-Ti coil springs. Am J Orthod Dentofacial Orthop 1996;109(1):8-21.

Meling TR, Odegaard J. The effect of short-term temperature changes on superelastic nickel-titanium archwires activated in orthodontic bending. Am J Orthod Dentofacial Orthop 2001;119(4):263-73.

Meling TR, Odegaard J. The effect of temperature on the elastic responses to longitudinal torsion of rectangular nickel titanium archwires. Angle Orthod 1998a;68(4):357-68.

Meling TR, Odegaard J. On the variability of cross-sectional dimensions and torsional properties of rectangular nickel-titanium arch wires. Am J Orthod Dentofacial Orthop 1998b;113(5):546-57.

Minervino BL, Pinto AS, Sakima MT, Guastaldi AC, Nakandakari C, Minervino EL. Características dos fios de "Memória de Forma" e aplicação clínica. Rev Dental Press Ordod Ortop Facial 2000; 5(4):72-6.

Miura F, Mogi M, Ohura Y. Japanese NiTi alloy wire: use of the direct electric resistance heat treatment method. Eur J Orthod 1988;10(3):187-91.

Miura F, Mogi M, Okamoto Y. New application of superelastic NiTi rectangular wire. J Clin Orthod 1990;24(9):544-8.

Miura F, Mogi M, Ohura $\mathrm{Y}$, Hamanaka $\mathrm{H}$. The super-elastic property of the Japanese NiTi alloy wire for use in orthodontics. Am J Orthod Dentofacial Orthop 1986;90(1):110.

Miyazaki S, Otsuka K. Deformation and transition behavior associated with the Rphase in Ti-Ni alloys. Metall Trans A 1986;17A:53-63. 
Miyazaki S, Wayman CM. The R-phase transition and associated shape memory mechanism in Ti-Ni single cristals. Acta Metallurgica 1988;36:181-92.

Mohlin B, Müller H, Ödman J, Thilander B. Examination of Chinese NiTi wire by a combined clinical and laboratory approach. Eur J Orthod 1991;13(5):386-91.

Muraviev SE, Ospanova GB, Shlyakhova MY. Estimation of force produced by nickel-titanium superelastic archwires at large deflections. Am J Orthod Dentofacial Orthop 2001;119(6):604-9.

Nakano H, Satoh K, Norris R, Jin T, Kamegai T, Ishikawa F, et al. Mechanical properties of several nickel-titanium alloy wires in three-point bending tests. Am J Orthod Dentofacial Orthop 1999;115(4):390-5.

Nardi E, Gambarini G, Tosti R. Archi preformati NiTi a sezione tonda: aspetti meccanici e clinici. Minerva Stomatol 1993;42(5):217-21.

Nikolai RJ, Anderson WT, Messersmith ML. Structural responses of orthodontic wires in flexure from a proposed alternative to the existing specification test. Am J Orthod Dentofacial Orthop 1988;93(6):496-504.

Nishio C, Motta AFJ, Elias CN, Mucha JN. In vitro evaluation of frictional forces between archwires and ceramic brackets. Am J Orthod Dentofacial Orthop 2004;125(1):56-64.

Parvizi F, Rock WP. The load/deflection characteristics of thermally activated orthodontic archwires. Eur J Orthod 2003;4(4):417-21.

Pratten DH, Popli K, Germane N, Gunsolley JC. Frictional resistance of ceramic and stainless steel orthodontic brackets. Am J Orthod Dentofacial Orthop 1990;98(5):398-403.

Proffit, WR. Ortodontia contemporânea. $3^{\underline{a}}$ ed. Trad de Jurandir Antônio Barbosa, Leonardo Bandle Filizzola. Rio de Janeiro: Guanabara Koogan, 2002.

Ramadan AA. Effect of nickel and chromium on gingival tissues during orthodontic treatment: a longitudinal study. World J Orthod 2004;5(3):230-5. 
Rock WP, Wilson $\mathrm{HJ}$. Forces exerted by orthodontic aligning archwires. $\mathrm{Br} \mathrm{J}$ Orthodont 1988;15(4):255-9.

Santoro M, Nicolay OF, Cangialosi TJ. Pseudoelasticity and thermoelasticity of nickel-titanium alloys: a clinically oriented review. Part II: Deactivation forces. Am J Orthod Dentofacial Orthop 2001a;119(6):594-603

Santoro M, Nicolay OF, Cangialosi TJ. Pseudoelasticity and thermoelasticity of nickel-titanium alloys: a clinically oriented review. Part I: Temperature transitional ranges. Am J Orthod Dentofacial Orthop 2001b;119(6):587-93.

Segner D, Ibe D. Properties of superelastic wires and their relevance to orthodontic treatment. Eur J Orthod 1995;17(5):395-402.

Sims APT, Waters NE, Birnie DJ. A comparison of the forces required to produce tooth movement ex vivo through three types of pre-adjusted brackets when subjected to determined tip or torque values. Br J Orthod 1994;21(4):367-73.

Stamm T, Hohoff A, Wiechmann D, Süfteld J, Helm D. Accuracy of third-order bends of nickel-titani um wires and the effect of high and low pressure during memorizing heat treatment. Am J Orthod Dentofacial Orthop 2004;126(4):477-85.

Thayer TA, Fox K, Meyer E. Nitinol total control: a new orthodontic alloy. J Clin Orthod 1999;33(10):563-7.

Thayer TA, Bagby MD, Moore RN, DeAngelis RJ. X-ray diffraction of nitinol orthodontic arch wires. Am J Orthod Dentofacial Orthop 1995;107(6):604-12.

Thorstenson GA, Kusy RP. Comparison of resistance to sliding between different self-ligating brackets with second-order angulation in the dry and saliva states. Am J Orthod Dentofacial Orthop 2002;121(5):472-82.

Thorstenson GA, Kusy RP. Effects of ligation type and method on the resistance to sliding of novel orthodontic brackets with second-order angulation in the dry and wet states. Angle Orthod 2003;73(4):418-30.

Thorstenson GA, Kusy RP. Resistance to sliding of self-ligating brackets versus conventional stainless steel twin brackets with second-order angulation in the dry and wet (saliva) states. Am J Orthod Dentofacial Orthop 2001;120(4):361-70. 
Waters NE. An improved method for the yield in bending of straight orthodontic wires. Br J Orthod 1981;8(2):89-98

Waters NE. Orthodontic products update - Superelastic nickel-titanium wires. $\mathrm{Br} \mathrm{J}$ Orthod 1992;19:319-22.

Waters NE, Stephens CD, Houston WJB. Physical characteristics of orthodontic wires and archwires - part 1. Br J Orthod 1975;2:15-24.

Yanuru K, Yamaguchi K, Kakigawa H, Kozono Y. Temperature- and deflectiondependences of orthodontic force with Ni-Ti wires. Dent Mater J 2003;22(2):146-59.

Yoneyama T, Doi H, Hamanaka H, Yamamoto M, Kuroda T. Bending properties and transformation temperatures of heat treatedi $\mathrm{Ni}$ - Ti alloy wire for orthodontic appliances. J Biomed Mater Res 1993;27(3):349-402.

Yoneyama T, Doi H, Hamanaka H, Okamoto Y, Mogi M, Miura F. Super-elasticity and thermal behavior of $\mathrm{Ni}-\mathrm{Ti}$ alloy orthodontic arch wires. Dent Mater $\mathrm{J}$ 1992;11(1):1-10. 


\section{GLOSSÁRIO}

Afastamento: Quanto está deslocado em relação à origem ou posição inicial à deflexão.

Carregamento: Etapa de ativação, em que a ponta ativa da máquina sai da posição zero até atingir a ativação máxima. Corresponde à fase em que o clínico insere o fio no canal do bráquete.

Descarregamento: Etapa de desativação, em que a ponta ativa da máquina, estando na ativação máxima, retorna à posição zero, ou seja, à origem. Corresponde à fase em que o fio exerce força sobre o dente para movimenta-lo.

Deslocamento: Movimento, mudar de posição.

Memória de forma: Propriedade do fio de retornar à sua forma original quando aquecido acima de determinada faixa de temperatura.

Origem: Posição zero, onde se inicia o movimento de carregamento.

Superelasticidade: Ou pseudo-elasticidade, propriedade pela qual um fio é capaz de desenvolver força constante, independente da quantidade de ativação. 
APÊNDICE A. - Curvas de ativação e desativação (força = função do afastamento da origem). Afastamento até (mm): I, 1mm; II, 2mm; III, 3mm; IV, $4 \mathrm{~mm}$.
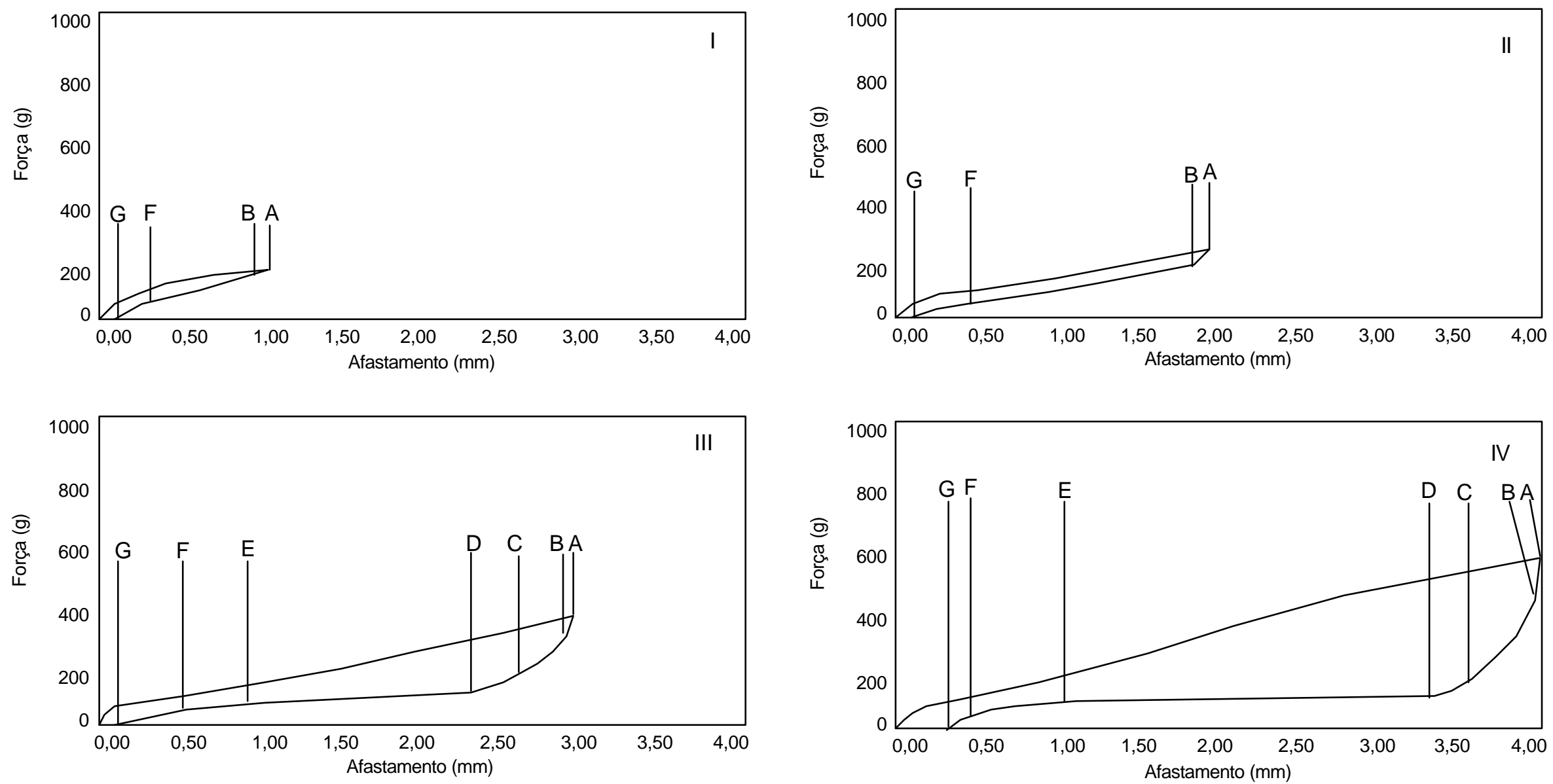
APÊNDICE B - Forças (g) máximas alcançadas

\begin{tabular}{|c|c|c|c|c|c|c|c|c|c|c|c|c|c|c|c|c|}
\hline \multirow{4}{*}{ Marca } & \multirow{4}{*}{$\begin{array}{c}\text { Ativação } \\
(\mathrm{mm})\end{array}$} & \multicolumn{15}{|c|}{ Temperatura $\left({ }^{\circ} \mathrm{C}\right)$} \\
\hline & & \multicolumn{5}{|c|}{32} & \multicolumn{5}{|c|}{37} & \multicolumn{5}{|c|}{42} \\
\hline & & \multicolumn{5}{|c|}{ Repetições } & \multicolumn{5}{|c|}{ Repetições } & \multicolumn{5}{|c|}{ Repetições } \\
\hline & & $1^{\underline{a}}$ & $2^{a}$ & $3^{\frac{a}{a}}$ & $4^{\underline{a}}$ & $5^{\mathrm{a}}$ & $1^{\underline{a}}$ & $2^{\underline{a}}$ & $3^{\frac{a}{a}}$ & $4^{\underline{a}}$ & $5^{\mathrm{a}}$ & $1^{\underline{a}}$ & $2^{\underline{a}}$ & $3^{\frac{a}{2}}$ & $4^{\frac{a}{2}}$ & $5^{\underline{a}}$ \\
\hline \multirow{4}{*}{ For } & 1 & 200 & 200 & 240 & 210 & 200 & 220 & 220 & 220 & 220 & 190 & 230 & 210 & 260 & 230 & 260 \\
\hline & 2 & 270 & 300 & 260 & 300 & 260 & 290 & 320 & 260 & 330 & 280 & 310 & 310 & 320 & 330 & 300 \\
\hline & 3 & 400 & 410 & 430 & 420 & 390 & 450 & 440 & 430 & 420 & 480 & 480 & 450 & 460 & 440 & 500 \\
\hline & 4 & 510 & 520 & 480 & 450 & 510 & 500 & 560 & 530 & 510 & 520 & 560 & 600 & 580 & 580 & 550 \\
\hline \multirow{4}{*}{ GAC } & 1 & 200 & 200 & 220 & 220 & 190 & 230 & 250 & 240 & 220 & 240 & 230 & 240 & 220 & 240 & 230 \\
\hline & 2 & 220 & 270 & 260 & 270 & 260 & 310 & 340 & 290 & 350 & 280 & 300 & 310 & 310 & 310 & 340 \\
\hline & 3 & 450 & 440 & 340 & 430 & 430 & 470 & 460 & 410 & 400 & 490 & 510 & 480 & 550 & 460 & 500 \\
\hline & 4 & 460 & 530 & 510 & 500 & 570 & 670 & 650 & 700 & 640 & 740 & 670 & 660 & 670 & 690 & 680 \\
\hline \multirow{4}{*}{ Mor } & 1 & 190 & 190 & 190 & 180 & 160 & 170 & 170 & 200 & 200 & 210 & 210 & 240 & 210 & 230 & 170 \\
\hline & 2 & 180 & 230 & 240 & 250 & 230 & 250 & 250 & 280 & 260 & 280 & 260 & 290 & 270 & 310 & 280 \\
\hline & 3 & 360 & 370 & 350 & 340 & 360 & 390 & 350 & 420 & 370 & 360 & 400 & 360 & 400 & 360 & 390 \\
\hline & 4 & 490 & 420 & 420 & 440 & 430 & 420 & 440 & 460 & 460 & 500 & 490 & 480 & 470 & 490 & 460 \\
\hline
\end{tabular}

APÊNDICE C - Diminuição das forças (g), após obtidas as máximas, com desativação de $0,20 \mathrm{~mm}$

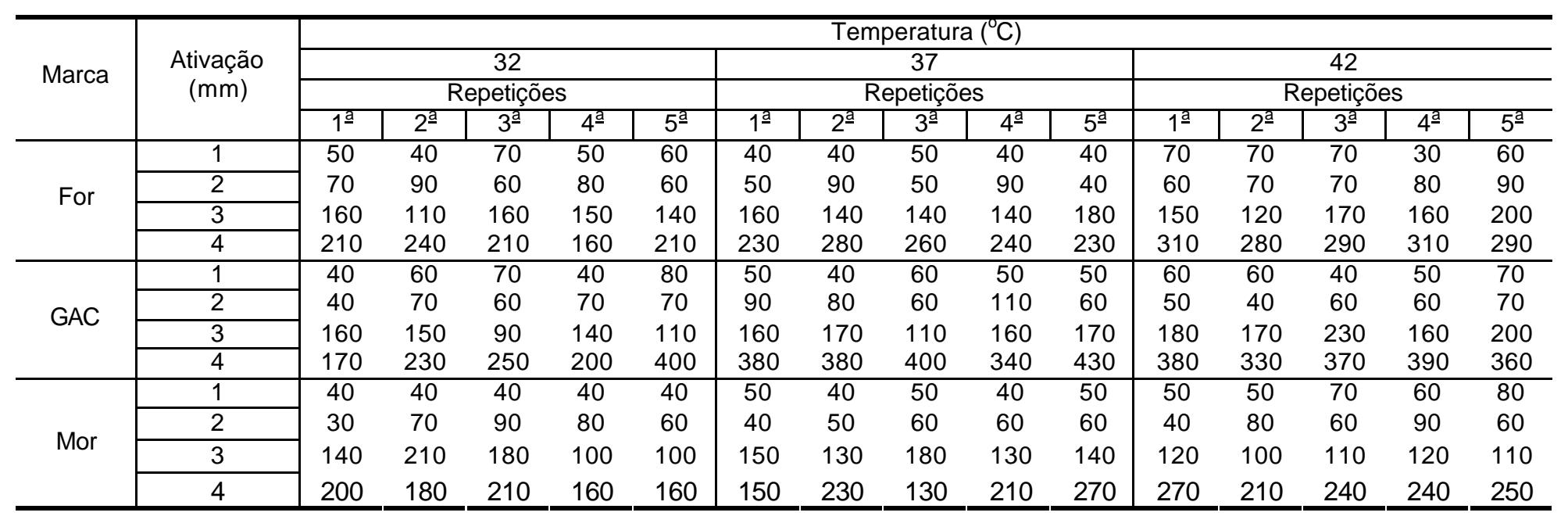


APÊNDICE C - Diminuição das forças (g) após obtidas as máximas, de 3 e 4 mm de ativações, com desativação de $0,70 \mathrm{~mm}$

\begin{tabular}{|c|c|c|c|c|c|c|c|c|c|c|c|c|c|c|c|c|}
\hline \multirow{4}{*}{ Marca } & \multirow{4}{*}{$\begin{array}{l}\text { Ativação } \\
(\mathrm{mm})\end{array}$} & \multicolumn{15}{|c|}{ Temperatura $\left({ }^{\circ} \mathrm{C}\right)$} \\
\hline & & \multicolumn{5}{|c|}{32} & \multicolumn{5}{|c|}{37} & \multicolumn{5}{|c|}{42} \\
\hline & & \multicolumn{5}{|c|}{ Repetições } & \multicolumn{5}{|c|}{ Repetições } & \multicolumn{5}{|c|}{ Repetições } \\
\hline & & $1^{\frac{a}{a}}$ & $2^{\underline{a}}$ & $3^{\frac{a}{3}}$ & $4^{\underline{a}}$ & $5^{\mathrm{a}}$ & $1^{\underline{a}}$ & $2^{-\underline{a}}$ & $3^{\frac{3}{2}}$ & $4^{\underline{a}}$ & $5^{-a}$ & $1^{\frac{a}{a}}$ & $2^{\underline{a}}$ & $3^{\frac{a}{a}}$ & $4^{\underline{a}}$ & $5^{-a}$ \\
\hline \multirow{2}{*}{ For } & 3 & 270 & 260 & 280 & 300 & 260 & 260 & 260 & 260 & 250 & 300 & 290 & 240 & 250 & 240 & 290 \\
\hline & 4 & 390 & 390 & 390 & 360 & 420 & 370 & 430 & 400 & 370 & 380 & 420 & 420 & 410 & 430 & 420 \\
\hline \multirow{2}{*}{ GAC } & 3 & 320 & $\overline{300}$ & 210 & 300 & 290 & 300 & 300 & 250 & 250 & 230 & 320 & 290 & 360 & 260 & 320 \\
\hline & 4 & 370 & 420 & 430 & 420 & 530 & 600 & 570 & 620 & 560 & 660 & 580 & 550 & 560 & 600 & 580 \\
\hline \multirow{2}{*}{ Mor } & 3 & 270 & 280 & 250 & 240 & 260 & 230 & 200 & 280 & 240 & 220 & 250 & 210 & 250 & 210 & 240 \\
\hline & 4 & 440 & 370 & 370 & 380 & 380 & 320 & 330 & 350 & 370 & 430 & 380 & 370 & 360 & 400 & 340 \\
\hline
\end{tabular}

APÊNDICE D - Extensão $(\mathrm{mm})$ dos platôs nas ativações de 3 e 4 mm

\begin{tabular}{|c|c|c|c|c|c|c|c|c|c|c|c|c|c|c|c|c|}
\hline \multirow{3}{*}{ Marca } & \multirow{3}{*}{$\begin{array}{l}\text { Ativação } \\
(\mathrm{mm})\end{array}$} & \multicolumn{15}{|c|}{ Temperatura $\left({ }^{\circ} \mathrm{C}\right)$} \\
\hline & & \multicolumn{5}{|c|}{32} & \multicolumn{5}{|c|}{37} & \multicolumn{5}{|c|}{42} \\
\hline & & $1^{a}$ & $2^{\underline{a}}$ & $3^{\frac{a}{2}}$ & $4^{\underline{a}}$ & $5^{\underline{a}}$ & $1^{\underline{a}}$ & $2^{\underline{a}}$ & $3^{a}$ & $4^{\underline{a}}$ & $5^{\mathrm{a}}$ & $1^{\underline{a}}$ & $2^{\underline{a}}$ & $3^{\underline{a}}$ & $4^{\underline{a}}$ & $5^{-a}$ \\
\hline For & 4 & 2,40 & 2,60 & 2,30 & 2,10 & 2,40 & 2,30 & 2,60 & 2,50 & 2,50 & 2,60 & 2,50 & 2,10 & 2,40 & 2,50 & 2,40 \\
\hline \multirow{2}{*}{ GAC } & 3 & 1,30 & 1,20 & 1,30 & 1,20 & 1,10 & 1,30 & 1,20 & 1,20 & 1,20 & 1,20 & 1,20 & 1,10 & 1,20 & 1,10 & 1,20 \\
\hline & 4 & 2,00 & 2,00 & 2,00 & 2,00 & 2,50 & 2,70 & 2,60 & 2,50 & 2,50 & 2,60 & 2,80 & 2,70 & 2,50 & 2,70 & 2,50 \\
\hline Mor & 3 & 0,50 & 0,50 & 0,50 & 0,60 & 0,80 & 0,40 & 0,60 & 1,20 & 0,90 & 0,70 & 0,80 & 0,60 & 0,90 & 0,80 & 0,60 \\
\hline
\end{tabular}


APÊNDICE E - Força média ponderada (g) no intervalo dos platôs

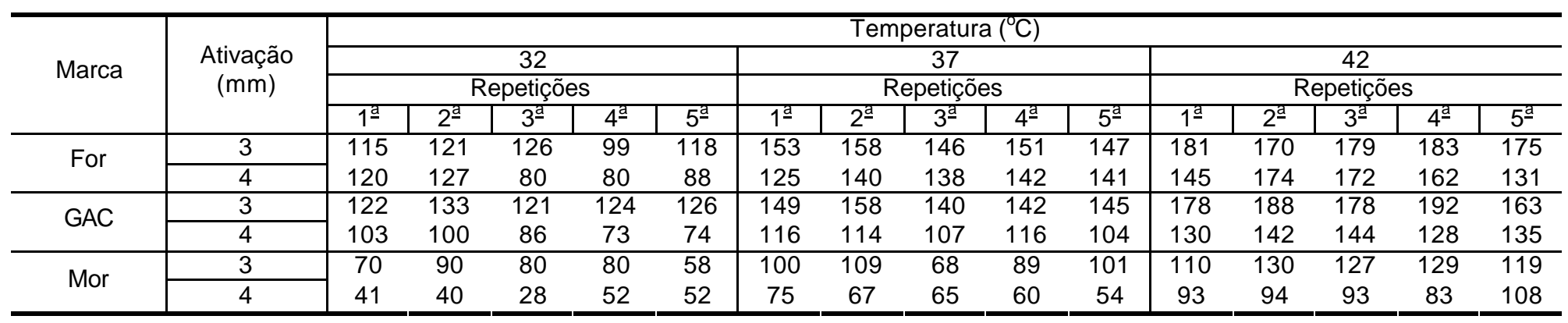

APÊNDICE F - Desativação $(\mathrm{mm})$ até atingir a força de $50 \mathrm{~g}$, desde 0,80 mm (com $1 \mathrm{~mm}$ de ativação), desde 1,80 mm (com $2 \mathrm{~mm}$ de ativação) e desde o final do platô (com 3 e 4 mm de ativação)

\begin{tabular}{|c|c|c|c|c|c|c|c|c|c|c|c|c|c|c|c|c|}
\hline \multirow{4}{*}{ Marca } & \multirow{4}{*}{$\begin{array}{c}\text { Ativação } \\
(\mathrm{mm})\end{array}$} & \multicolumn{15}{|c|}{ Temperatura $\left({ }^{\circ} \mathrm{C}\right)$} \\
\hline & & \multicolumn{5}{|c|}{32} & \multicolumn{5}{|c|}{37} & \multicolumn{5}{|c|}{42} \\
\hline & & \multicolumn{5}{|c|}{ Repetições } & \multicolumn{5}{|c|}{ Repetições } & \multicolumn{5}{|c|}{ Repetições } \\
\hline & & $1^{-\frac{a}{-}}$ & $2^{\underline{a}}$ & $3^{a}$ & $4^{\underline{a}}$ & $5^{\mathrm{a}}$ & $1^{\frac{a}{a}}$ & $2^{a}$ & $3^{\frac{3}{2}}$ & $4^{-\underline{a}}$ & $5^{\mathrm{a}}$ & $1^{\underline{a}}$ & $2^{a}$ & $3^{\frac{a}{2}}$ & $4^{\underline{a}}$ & $5^{a}$ \\
\hline \multirow{4}{*}{ For } & 1 & 0,40 & 0,35 & 0,47 & 0,40 & 0,35 & 0,58 & 0,54 & 0,40 & 0,54 & 0,45 & 0,37 & 0,27 & 0,45 & 0,44 & 0,47 \\
\hline & 2 & 1,30 & 1,27 & 1,20 & 1,30 & 1,27 & 1,40 & 1,45 & 1,40 & 1,40 & 1,40 & 1,20 & 1,37 & 1,44 & 1,35 & 1,25 \\
\hline & 3 & 0,45 & 0,40 & 0,35 & 0,60 & 0,45 & 0,65 & 0,55 & 0,97 & 0,57 & 0,70 & 0,67 & 0,64 & 0,64 & 0,60 & 0,34 \\
\hline & 4 & 0,40 & 0,37 & 0,10 & 0,15 & 0,05 & 0,54 & 0,85 & 0,30 & 0,35 & 0,40 & 0,30 & 0,40 & 0,47 & 0,34 & 0,30 \\
\hline \multirow{4}{*}{ GAC } & 1 & 0,50 & 0,30 & 0,38 & 0,44 & 0,15 & 0,36 & 0,45 & 0,38 & 0,32 & 0,50 & 0,37 & 0,34 & 0,44 & 0,37 & 0,34 \\
\hline & 2 & 1,12 & 1,17 & 1,15 & 1,30 & 1,22 & 1,35 & 1,50 & 1,27 & 1,45 & 1,25 & 0,96 & 1,25 & 1,24 & 1,18 & 1,40 \\
\hline & 3 & 0,25 & 0,30 & 0,50 & 0,30 & 0,35 & 0,25 & 0,47 & 0,50 & 0,54 & 0,34 & 0,38 & 0,45 & 0,30 & 0,55 & 0,30 \\
\hline & 4 & 0,10 & 0,10 & 0,04 & 0,10 & $-0,05$ & 0,07 & 0,07 & 0,04 & 0,04 & 0,10 & 0,14 & 0,13 & 0,10 & 0,05 & 0,13 \\
\hline \multirow{4}{*}{ Mor } & 1 & 0,40 & 0,37 & 0,37 & 0,34 & 0,40 & 0,40 & 0,45 & 0,45 & 0,50 & 0,50 & 0,33 & 0,50 & 0,33 & 0,40 & 0,13 \\
\hline & 2 & 0,85 & 1,00 & 1,05 & 1,10 & 1,00 & 1,30 & 1,30 & 1,45 & 1,35 & 1,40 & 1,10 & 1,20 & 1,27 & 1,27 & 1,50 \\
\hline & 3 & 0,30 & 0,80 & 0,30 & 0,30 & 0,30 & 1,20 & 0,80 & 0,20 & 0,40 & 0,40 & 0,50 & 0,70 & 0,60 & 0,60 & 0,60 \\
\hline & 4 & $-0,20$ & $-0,40$ & $-0,90$ & $-0,40$ & $-0,50$ & 0,30 & 0,10 & 0,10 & 0,00 & $-0,10$ & 0,40 & 0,37 & 0,37 & 0,20 & 1,10 \\
\hline
\end{tabular}


APÊNDICE G - Força ao iniciar a desativação até $50 \mathrm{~g}$ desde 0,80 e 1,80 mm (respectivamente com 1 e $2 \mathrm{~mm}$ de ativação) e desde o final do platô (3 e 4 mm de ativação)

\begin{tabular}{|c|c|c|c|c|c|c|c|c|c|c|c|c|c|c|c|c|}
\hline \multirow{4}{*}{ Marca } & \multirow{4}{*}{$\begin{array}{l}\text { Ativação } \\
(\mathrm{mm})\end{array}$} & \multicolumn{15}{|c|}{ Temperatura $\left({ }^{\circ} \mathrm{C}\right)$} \\
\hline & & \multicolumn{5}{|c|}{32} & \multicolumn{5}{|c|}{37} & \multicolumn{5}{|c|}{42} \\
\hline & & \multicolumn{5}{|c|}{ Repetições } & \multicolumn{5}{|c|}{ Repetições } & \multicolumn{5}{|c|}{ Repetições } \\
\hline & & $1^{-\underline{a}}$ & $2^{-\underline{a}}$ & $3^{\frac{3}{a}}$ & $4^{\underline{a}}$ & $5^{-\underline{a}}$ & $1^{-\underline{a}}$ & $2^{\underline{a}}$ & $3^{\underline{a}}$ & $4^{\underline{a}}$ & $5^{\underline{a}}$ & $1^{-\underline{a}}$ & $2^{a}$ & $3^{\mathrm{a}}$ & $4^{\underline{a}}$ & $5^{\underline{a}}$ \\
\hline \multirow{4}{*}{ For } & 1 & 150 & 160 & 170 & 160 & 140 & 180 & 180 & 170 & 180 & 150 & 160 & 140 & 190 & 200 & 200 \\
\hline & 2 & 200 & 210 & 200 & 220 & 200 & 240 & 230 & 210 & 240 & 240 & 250 & 240 & 250 & 250 & 240 \\
\hline & 3 & 110 & 110 & 110 & 110 & 110 & 150 & 150 & 140 & 140 & 140 & 170 & 180 & 170 & 170 & 170 \\
\hline & 4 & 110 & 110 & 70 & 70 & 60 & 110 & 120 & 120 & 120 & 120 & 130 & 160 & 170 & 130 & 100 \\
\hline \multirow{4}{*}{ GAC } & 1 & 160 & 140 & 150 & 180 & 110 & 180 & 210 & 180 & 170 & 190 & 170 & 180 & 180 & 190 & 160 \\
\hline & 2 & 180 & 200 & 200 & 200 & 190 & 220 & 260 & 230 & 240 & 220 & 250 & 270 & 250 & 250 & 270 \\
\hline & 3 & 100 & 120 & 110 & 110 & 110 & 130 & 150 & 140 & 130 & 130 & 160 & 170 & 160 & 190 & 140 \\
\hline & 4 & 70 & 100 & 60 & 60 & 40 & 70 & 80 & 60 & 60 & 70 & 90 & 90 & 90 & 70 & 90 \\
\hline \multirow{4}{*}{ Mor } & 1 & 150 & 150 & 150 & 140 & 120 & 120 & 130 & 150 & 160 & 160 & 160 & 190 & 140 & 170 & 90 \\
\hline & 2 & 150 & 160 & 150 & 170 & 170 & 210 & 200 & 220 & 200 & 220 & 220 & 210 & 210 & 220 & 220 \\
\hline & 3 & 60 & 80 & 70 & 70 & 50 & 90 & 100 & 60 & 80 & 90 & 100 & 120 & 120 & 120 & 110 \\
\hline & 4 & 30 & 20 & 30 & 30 & 30 & 70 & 60 & 60 & 50 & 40 & 90 & 90 & 90 & 70 & 100 \\
\hline
\end{tabular}

APÊNDICE H - Afastamento $(\mathrm{mm})$ da origem ao atingir $50 \mathrm{~g}$

\begin{tabular}{|c|c|c|c|c|c|c|c|c|c|c|c|c|c|c|c|c|}
\hline \multirow{4}{*}{ Marca } & \multirow{4}{*}{$\begin{array}{c}\text { Ativação } \\
(\mathrm{mm})\end{array}$} & \multicolumn{15}{|c|}{ Temperatura $\left({ }^{\circ} \mathrm{C}\right)$} \\
\hline & & \multicolumn{5}{|c|}{32} & \multicolumn{5}{|c|}{37} & \multicolumn{5}{|c|}{42} \\
\hline & & \multicolumn{5}{|c|}{ Repetições } & \multicolumn{5}{|c|}{ Repetições } & \multicolumn{5}{|c|}{ Repetições } \\
\hline & & $1^{\underline{a}}$ & $2^{\underline{a}}$ & $3^{\underline{a}}$ & $4^{\underline{a}}$ & $5^{\underline{a}}$ & $1^{\underline{a}}$ & $2^{\underline{a}}$ & $3^{a}$ & $4^{\underline{a}}$ & $5^{\underline{a}}$ & $1^{\underline{a}}$ & $2^{\underline{a}}$ & $3^{\underline{a}}$ & $4^{\underline{a}}$ & $5^{\underline{a}}$ \\
\hline \multirow{4}{*}{ For } & 1 & 0,40 & 0,45 & 0,33 & 0,40 & 0,45 & 0,22 & 0,26 & 0,40 & 0,26 & 0,35 & 0,43 & 0,53 & 0,35 & 0,36 & 0,33 \\
\hline & 2 & 0,50 & 0,53 & 0,60 & 0,50 & 0,53 & 0,40 & 0,35 & 0,40 & 0,40 & 0,40 & 0,60 & 0,43 & 0,36 & 0,45 & 0,55 \\
\hline & 3 & 0,65 & 0,70 & 0,45 & 0,70 & 0,85 & 0,35 & 0,45 & 0,43 & 0,53 & 0,40 & 0,43 & 0,66 & 0,46 & 0,50 & 0,46 \\
\hline & 4 & 0,50 & 0,53 & 0,90 & 1,05 & 0,75 & 0,56 & 0,35 & 0,50 & 0,45 & 0,40 & 0,60 & 0,70 & 0,53 & 0,46 & 0,50 \\
\hline \multirow{4}{*}{ GAC } & 1 & 0,30 & 0,50 & 0,42 & 0,36 & 0,65 & 0,44 & 0,35 & 0,42 & 0,48 & 0,30 & 0,43 & 0,46 & 0,36 & 0,43 & 0,46 \\
\hline & 2 & 0,68 & 0,63 & 0,65 & 0,50 & 0,58 & 0,45 & 0,30 & 0,53 & 0,35 & 0,55 & 0,84 & 0,55 & 0,56 & 0,62 & 0,40 \\
\hline & 3 & 0,55 & 0,70 & 0,60 & 0,80 & 0,65 & 0,55 & 0,63 & 0,60 & 0,66 & 0,56 & 0,62 & 0,75 & 0,60 & 0,75 & 0,60 \\
\hline & 4 & 1,20 & 1,20 & 1,16 & 1,30 & 0,65 & 0,53 & 0,63 & 0,66 & 0,76 & 0,60 & 0,56 & 0,57 & 0,80 & 0,55 & 0,67 \\
\hline \multirow{4}{*}{ Mor } & 1 & 0,40 & 0,43 & 0,43 & 0,46 & 0,40 & 0,40 & 0,35 & 0,35 & 0,30 & 0,30 & 0,47 & 0,30 & 0,47 & 0,40 & 0,67 \\
\hline & 2 & 0,95 & 0,80 & 0,75 & 0,70 & 0,80 & 0,50 & 0,50 & 0,35 & 0,45 & 0,40 & 0,70 & 0,60 & 0,53 & 0,53 & 0,30 \\
\hline & 3 & 1,40 & 1,30 & 1,40 & 1,30 & 1,20 & 0,30 & 0,70 & 0,50 & 0,70 & 0,90 & 0,70 & 0,90 & 0,70 & 0,80 & 0,90 \\
\hline & 4 & 1,00 & 3,20 & 3,30 & 3,00 & 3,10 & 0,90 & 0,90 & 0,60 & 1,00 & 0,70 & 0,90 & 0,83 & 0,93 & 0,60 & 0,80 \\
\hline
\end{tabular}


APÊNDICE I - Deformação (mm) permanente, ao alcançar força zero

\begin{tabular}{|c|c|c|c|c|c|c|c|c|c|c|c|c|c|c|c|c|}
\hline \multirow{4}{*}{ Marca } & \multirow{4}{*}{$\begin{array}{c}\text { Ativação } \\
(\mathrm{mm})\end{array}$} & \multicolumn{15}{|c|}{ Temperatura $\left({ }^{\circ} \mathrm{C}\right)$} \\
\hline & & \multicolumn{5}{|c|}{32} & \multicolumn{5}{|c|}{37} & \multicolumn{5}{|c|}{42} \\
\hline & & \multicolumn{5}{|c|}{ Repetições } & \multicolumn{5}{|c|}{ Repetições } & \multicolumn{5}{|c|}{ Repetições } \\
\hline & & $1^{\frac{a}{-}}$ & $2^{\underline{a}}$ & $3^{\frac{s}{a}}$ & $4^{a}$ & $5^{\underline{a}}$ & $1^{\underline{a}}$ & $2^{a}$ & $3^{-\underline{a}}$ & $4^{a}$ & $5^{-\underline{a}}$ & $1^{\frac{a}{a}}$ & $2^{\underline{a}}$ & $3^{a}$ & $4^{-a}$ & $5^{\underline{a}}$ \\
\hline \multirow{4}{*}{ For } & 1 & 0,10 & 0,30 & 0,10 & 0,20 & 0,20 & 0,00 & 0,10 & 0,20 & 0,10 & 0,10 & 0,20 & 0,30 & 0,10 & 0,20 & 0,10 \\
\hline & 2 & 0,20 & 0,30 & 0,40 & 0,20 & 0,30 & 0,20 & 0,10 & 0,20 & 0,10 & 0,20 & 0,40 & 0,20 & 0,20 & 0,20 & 0,30 \\
\hline & $\overline{3}$ & 0,30 & 0,30 & 0,20 & 0,40 & 0,50 & 0,10 & 0,20 & 0,10 & 0,20 & 0,10 & 0,20 & 0,50 & 0,20 & 0,30 & 0,00 \\
\hline & 4 & 0,10 & 0,30 & 0,50 & 0,70 & 0,40 & 0,30 & 0,10 & 0,20 & 0,20 & 0,10 & 0,40 & 0,50 & 0,30 & 0,30 & 0,20 \\
\hline \multirow{4}{*}{ GAC } & 1 & 0,10 & 0,30 & 0,20 & 0,30 & 0,50 & 0,30 & 0,20 & 0,20 & 0,30 & 0,10 & 0,20 & 0,30 & 0,20 & 0,20 & 0,30 \\
\hline & 2 & 0,50 & 0,40 & 0,50 & 0,20 & 0,40 & 0,20 & 0,10 & 0,30 & 0,10 & 0,40 & 0,70 & 0,40 & 0,40 & 0,50 & 0,20 \\
\hline & $\frac{5}{3}$ & 0,30 & 0,50 & 0,40 & 0,60 & 0,40 & 0,40 & 0,40 & 0,40 & 0,50 & 0,40 & 0,50 & 0,60 & 0,40 & 0,60 & 0,40 \\
\hline & 4 & 1,00 & 1,00 & 0,50 & 1,10 & 0,40 & 0,40 & 0,40 & 0,50 & 0,60 & 0,40 & 0,40 & 0,40 & 0,60 & 0,40 & 0,50 \\
\hline \multirow{4}{*}{ Mor } & 1 & 0,20 & 0,20 & 0,20 & 0,30 & 0,10 & 0,10 & 0,10 & 0,10 & 0,10 & 0,10 & 0,30 & 0,10 & 0,30 & 0,20 & 0,50 \\
\hline & 2 & 0,60 & 0,50 & 0,50 & 0,40 & 0,50 & 0,30 & 0,20 & 0,10 & 0,20 & 0,10 & 0,50 & 0,30 & 0,30 & 0,30 & 0,10 \\
\hline & 3 & 0,60 & 0,50 & 0,80 & 0,80 & 0,70 & 0,00 & 0,30 & 0,20 & 0,30 & 0,20 & 0,30 & 0,60 & 0,30 & 0,60 & 0,50 \\
\hline & 4 & 0,60 & 1,10 & 1,30 & 1,00 & 0,80 & 0,30 & 0,40 & 0,00 & 0,60 & 0,20 & 0,50 & 0,40 & 0,60 & 0,20 & 0,50 \\
\hline
\end{tabular}

